\title{
Audit quality in a regulatory context
}

\author{
Citation for published version (APA):
}

van Opijnen, M. (2016). Audit quality in a regulatory context: empirical studies on public oversight, auditor independence, and audit quality indicators. [Doctoral Thesis, Maastricht University]. Maastricht University. https://doi.org/10.26481/dis.20160518mo

Document status and date:

Published: 01/01/2016

DOI:

10.26481/dis.20160518mo

Document Version:

Publisher's PDF, also known as Version of record

\section{Please check the document version of this publication:}

- A submitted manuscript is the version of the article upon submission and before peer-review. There can be important differences between the submitted version and the official published version of record.

People interested in the research are advised to contact the author for the final version of the publication, or visit the DOI to the publisher's website.

- The final author version and the galley proof are versions of the publication after peer review.

- The final published version features the final layout of the paper including the volume, issue and page numbers.

Link to publication

\footnotetext{
General rights rights.

- You may freely distribute the URL identifying the publication in the public portal. please follow below link for the End User Agreement:

www.umlib.nl/taverne-license

Take down policy

If you believe that this document breaches copyright please contact us at:

repository@maastrichtuniversity.nl

providing details and we will investigate your claim.
}

Copyright and moral rights for the publications made accessible in the public portal are retained by the authors and/or other copyright owners and it is a condition of accessing publications that users recognise and abide by the legal requirements associated with these

- Users may download and print one copy of any publication from the public portal for the purpose of private study or research.

- You may not further distribute the material or use it for any profit-making activity or commercial gain

If the publication is distributed under the terms of Article $25 \mathrm{fa}$ of the Dutch Copyright Act, indicated by the "Taverne" license above, 


\section{AUDIT QUALITY IN A REGULATORY CONTEXT}

Empirical Studies on Public Oversight,

Auditor Independence,

and Audit Quality Indicators

Martijn van Opijnen 
(c) Copyright Martijn van Opijnen, Utrecht, The Netherlands, 2016

All rights reserved. No part of this publication may be reproduced, stored in a retrieval system, or transmitted in any form or by any means, electronically, mechanically, photocopying, recording or otherwise, without the prior permission in writing from the author.

Cover and layout by De Weijer Design B.V., Baarn

Printed by CPI Koninklijke Wöhrmann B.V., Zutphen

ISBN 9789463280365

The research in this doctoral dissertation was supported by the Netherlands Authority for the Financial Markets. This dissertation was written in a personal capacity. All views and conclusions are those of the author(s) and should not in any way be attributed to the Netherlands Authority for the Financial Markets, unless otherwise stated. 


\title{
AUDIT QUALITY IN A REGULATORY CONTEXT
}

\author{
Empirical Studies on Public Oversight, \\ Auditor Independence, \\ and Audit Quality Indicators
}

\begin{abstract}
DISSERTATION
to obtain the degree of Doctor at the Maastricht University, on the authority of the Rector Magnificus,

Prof. dr. L.L.G. Soete,

in accordance with the decision of the Board of Deans,

to be defended in public

on Wednesday May 18, 2016, at 16:00 hours
\end{abstract}

by

Martijn van Opijnen 


\section{Supervisors:}

Prof. dr. A. Vanstraelen

Prof. dr. J.C. Bedard (Bentley University, United States of America)

\section{Assessment Committee:}

Prof. dr. R.H.G. Meuwissen (Chairman)

Prof. dr. M.A. Carree

Prof. dr. S.J. Maijoor (Vrije Universiteit Amsterdam)

Prof. dr. R. Simnett (University of New South Wales, Australia) 


\section{AUDIT QUALITY IN A REGULATORY CONTEXT}

Empirical Studies on Public Oversight,

Auditor Independence, and Audit Quality Indicators 



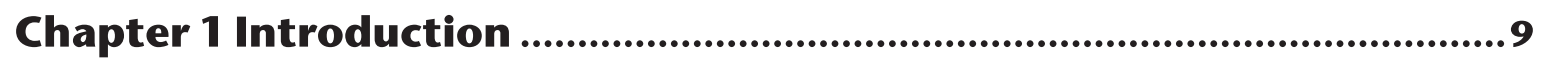

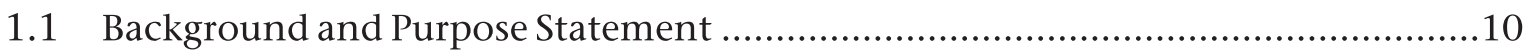

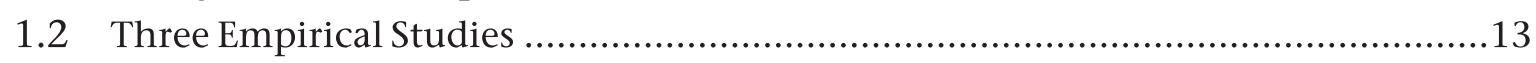

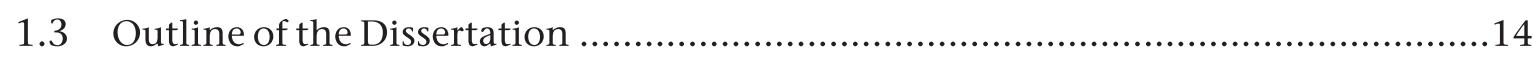

Chapter 2 Public Oversight and Audit Quality: ............................................... 15 Evidence from First-Time Inspections of Dutch Audit Firms

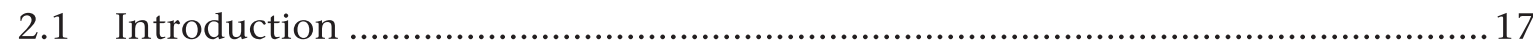

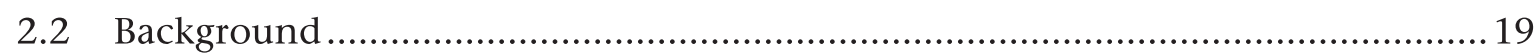

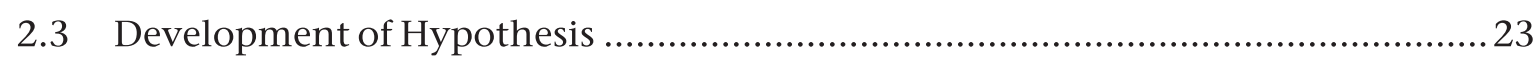

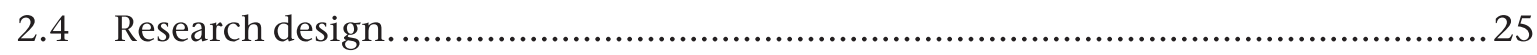

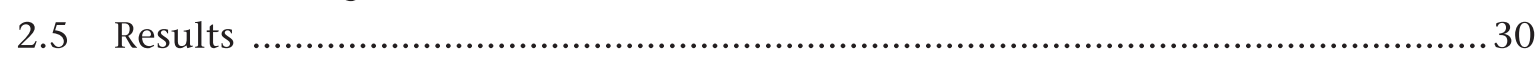

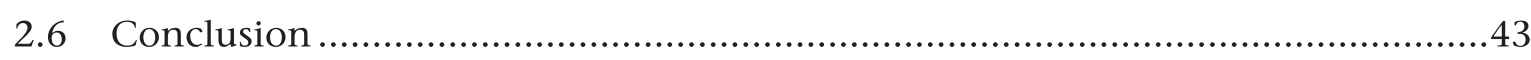

Chapter 3 Business Relationships and Auditor Independence: ...............47 When Audit Firms are Their Clients' Clients

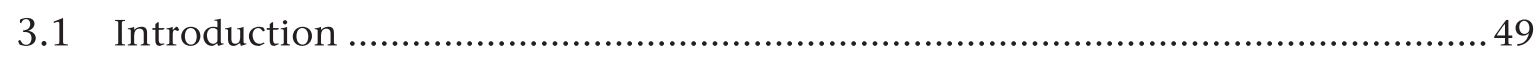

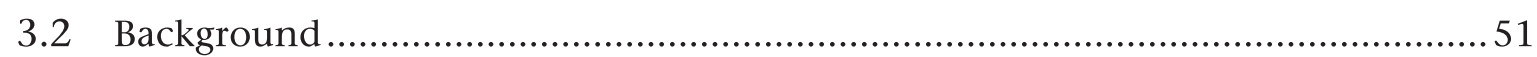

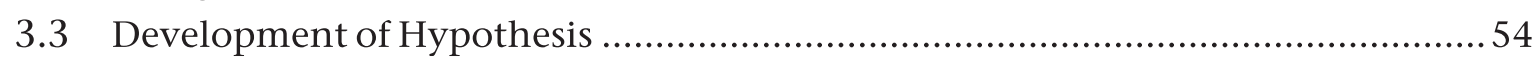

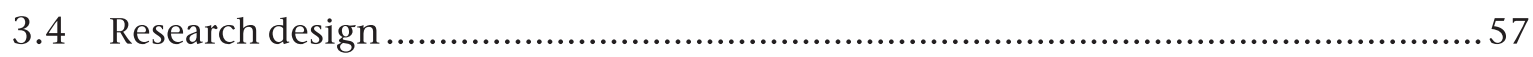

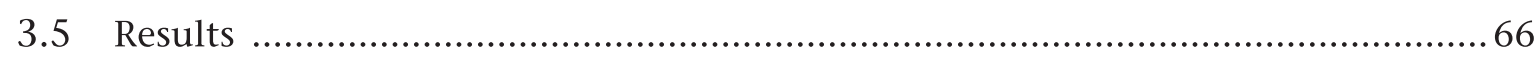

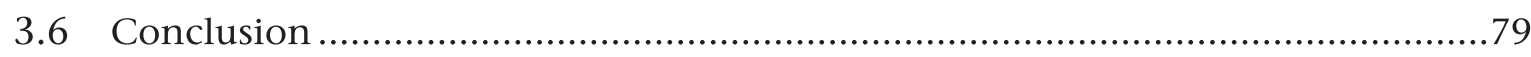

Chapter 4 Audit Firm Governance and Audit Firm Quality: ...................81 An Examination of Audit Quality Indicators

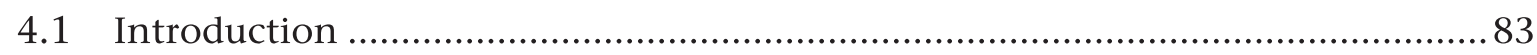

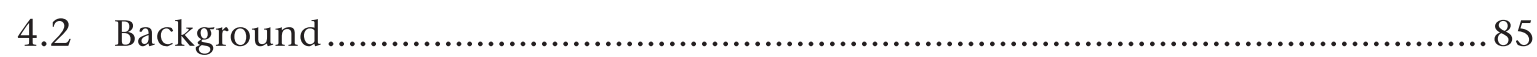

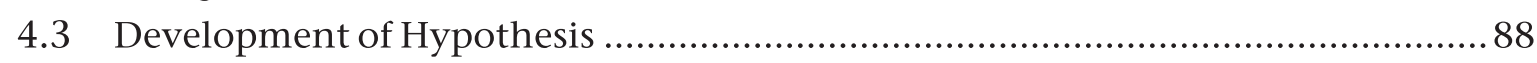

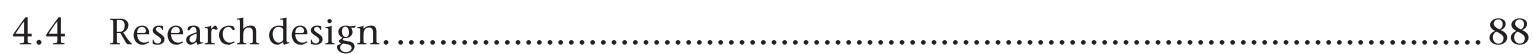

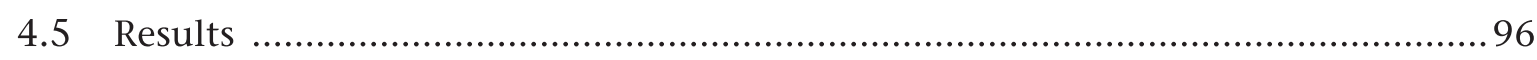

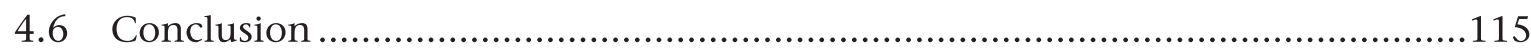


Chapter 5 Conclusion...................................................................... 117

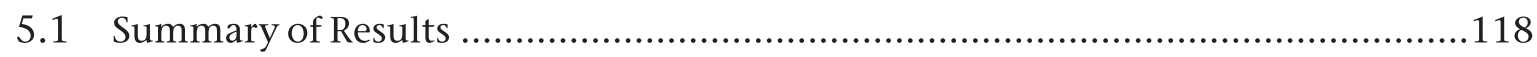

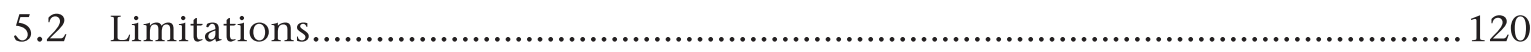

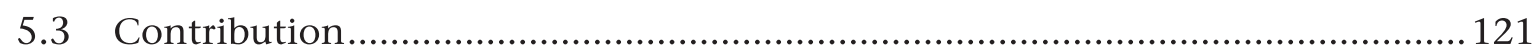

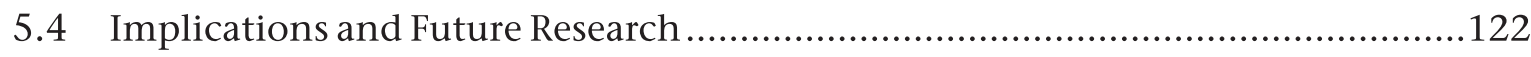

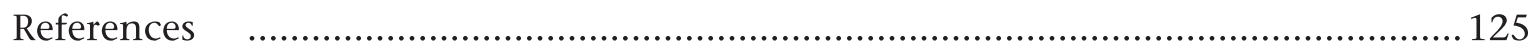

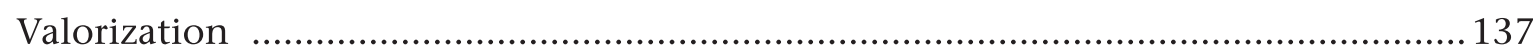

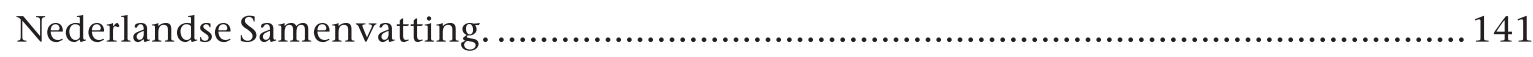

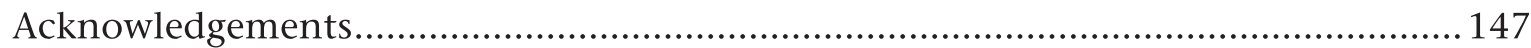

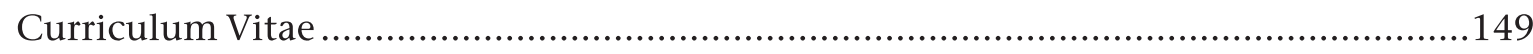


Chapter 1

Introduction 


\subsection{Background and Purpose Statement}

This dissertation investigates how the quality of auditing of financial statements relates to the regulatory context in which audits are performed. Auditing is the process of providing assurance about the reliability of the information contained in financial statements prepared in accordance with generally accepted accounting principles (Knechel 2001). Auditing is also a professional service delivered by experts in response to economic and regulatory demand (Knechel et al. 2013). Many stakeholders are basing economic decisions on information in companies' financial statements. Those users of financial statements, which include capital providers such as shareholders and creditors, and otherstakeholders such as suppliers, customers and employees, need thosestatements to provide reliable information regarding the company's financial position. Usually, they are not in a position to evaluate the reliability of the financial statements, because they do not have access to the underlying data, they lack the skills to do so, and it would be too costly. Therefore, they have an information disadvantage compared to the company's management. The interests of company's management, which is responsible for providing the information, and the users of that information, may not be aligned. In fact, it is widely agreed that these interests are often conflicting: while users of financial statements require relevant and reliable information, company's management may have incentives, for instance personal bonuses, to present the information more favorably. Auditors are the independent professionals hired to provide a competent and objective opinion on the reliability of the information. In doing so, they improve the quality of that information and reduce the information disadvantage of the users of financial statements. Auditors thus operate primarily in the public interest.

At the same time, auditors are operating in a system with incentives that may negatively influence the quality of the audits they perform (AFM 2014). First, they are paid by the companies whose financial statements they audit but from whom they need to be independent. The auditor has to balance the public interest of performing an objective and critical audit and the client company's interests of providing high-level service to retain the client's business. Second, an audit can be considered a credence good: the quality of an audit is practically unobservable, both for the users of financial statements and the audited company (Causholli and Knechel 2012). Only the auditor has both access to all the underlying information and the expertise and the professional judgment needed to plan and perform the audit in accordance with the professional auditing standards. Neither the users of financial statements nor the audited company are able to assess whether the auditor made the right decisions during the audit. In the end, they are also unable to assess whether the audit has reduced the risk of material misstatements in the financial statements to an acceptably low level. Third, auditors have organized themselves in audit firms and are performing audits as a commercial business enterprise with an aim of making a profit. Besides audit, they are also providing other services to clients and they are collaborating with other professionals within their firm or their network, e.g., tax and management consultants, and legal experts. Auditors 
need to balance their own business objectives, e.g., growth, efficiency and profit maximization, with the objectives for audit quality set by regulation.

The incentives that may negatively influence the quality of audits have created the need for professional standards and regulation to ensure a constant and adequate level of auditing. Auditing is, or has become, a highly regulated profession. International legislators (e.g., the European Union) and regulators (e.g., the International Auditing and Assurance Standards Board (IAASB) and the International Ethics Standards Board for Accountants (IESBA)), as well as national legislators and regulators (e.g., professional bodies) have defined a wide spectrum of requirements for the auditing profession. Those requirements are on the one hand focused at the individual auditor level. For instance, auditors need to follow a predetermined educational track consisting of both theoretical and practical training, and take part in appropriate programs of continuing education in order to maintain their theoretical knowledge, professional skills and values at a sufficiently high level and to attain and maintain their audit qualification. Professional bodies keep register of qualified auditors. Registered auditors are further required to comply with applicable professional ethical standards, including independence regulations, and auditing standards. On the other hand, requirements are focused at the audit firm level. Audit firms are responsible for establishing and maintaining systems of quality control that include policies and procedures that provide them with reasonable assurance that: (a) the firm and its personnel comply with professional standards and applicable legal and regulatory requirements; and (b) reports issued by the firm or engagement partners are appropriate in the circumstances. Initially, peer review systems were employed to have audit firms or auditors assess each other's quality control systems and quality of audit files.

A number of large audit failures and accounting scandals in the early 2000s (e.g., Enron, WorldCom, Xerox, Ahold, and Parmalat) have severely undermined public confidence in auditors and their reports. Worldwide, regulators have responded by increasing their regulatory focus on audit firms in the course of the last fifteen years. Three of those regulatory topics are at the heart of this dissertation: the introduction of independent public oversight, the strengthening of auditor independence, and the development of audit quality indicators to increase audit firm transparency.

One of the most fundamental changes in the history of the auditing profession is the installment of independent public oversight bodies in many countries in the first decade of the 21st century, replacing the auditing profession's self-regulatory peer review system. This regulatory move was triggered by the high-profile corporate failures, which made regulators believe that the peer review system was no longer adequate and appropriately functioning. Independent public oversight was proposed instead as an alternative way of organizing audit oversight with the goal of restoring confidence in and safeguarding the public function of the auditing profession and the quality of its work.

At the same time, regulators around the world started to tighten independence requirements, or considered to do so, in an attempt to improve audit quality and to regain public trust in the auditors' reports. Many countries introduced a ban on (most) 
other services for audit clients that were considered public interest entities (PIEs; i.e., listed companies, credit institutions and insurance companies). Furthermore, in addition to the individual partner rotation requirements already in place, audit firm rotation was considered or even already introduced. These initiatives are indicative of a commonly shared belief that auditors' and audit firms' independence must be further strengthened, not only in fact, but also in appearance, in order to safeguard audit quality.

Audit firm governance (i.e., the audit firm's governance structure, quality control policies, human resource policies, independence and ethics) became an increasingly important issue on the agenda of regulators. The governance of an audit firm is expected to have a significant influence on the audit quality delivered by (the auditors of) that firm. Increasing the transparency of those governance and professional practices, particularly in the form of publishing audit quality indicators, is high on the regulators' agendas. Transparency of audit firms through audit quality indicators is believed to increase market participants' ability to observe audit quality, thus enabling differentiation and competition among audit firms on the basis of publicly available data, and providing incentives for firms to increase audit quality (e.g., Bedard et al. 2010; PCAOB 2015).

The purpose of this dissertation is to empirically assess how these regulatory topics (i.e., public oversight, auditor independence, and audit quality indicators) relate to audit quality. Exploiting the unique access to proprietary data on audit firms from the Dutch public oversight body, this dissertation contributes to the existing literature on these topics by shedding new light on various audit quality aspects.

Prior literature provides guidance on how to approach audit quality research by suggesting how to define and measure audit quality. Users, auditors, regulators, and society-all stakeholders in the financial reporting process-may have very different views as to what constitutes audit quality (Knechel et al. 2013), resulting in different definitions to be found in the auditing literature. First, the quality of audit services can be defined as the market-assessed joint probability that a given auditor will both (a) discover a breach in the client's accounting system, and (b) report the breach (DeAngelo 1981b; Watts and Zimmerman 1983). The probability that a given auditor will discover a breach depends on the auditor's technological capabilities, the audit procedures employed on a given audit, the extent of sampling, etc. The conditional probability of reporting a discovered breach is a measure of an auditor's independence from a given client. Alternatively, one might conclude that a 'good' audit is one where there is execution of a well-designed audit process by properly motivated and trained auditors who understand the inherent uncertainty of the audit and appropriately adjust to the unique conditions of the client (Knechel et al. 2013). From yet another perspective, higher audit quality can be defined as greater assurance that the financial statements faithfully reflect the company's underlying economics, conditioned on its financial reporting system and innate characteristics (DeFond and Zhang 2014). Finally, audit quality can be considered a complex concept which is impossible to reduce to a simple definition, and it can be 
argued there are gradations of audit quality across a continuum from low- to high-quality audits, and that quality is affected by each of the following units of analysis (Francis 2011, 126): (a) audit inputs; (b) audit processes; (c) accounting firms; (d) audit industry and audit markets; (e) institutions; and (f) economic consequences of audit outcomes.

The three studies in this dissertation build upon these definitions and suggested units of analysis in their examination of the relationship between the three regulatory topics and audit quality.

\subsection{Three Empirical Studies}

This dissertation includes three empirical studies on how the previously described regulatory topics (i.e., public oversight, auditor independence, and audit quality indicators) relate to audit quality. All three studies exploit the unique access to proprietary data on audit firms from the Dutch public oversight body, thereby contributing to the existing literature on these topics by shedding new light on various audit quality aspects.

Chapter 2 presents the first study, which is about public oversight and audit quality. In this chapter, the effectiveness of public oversight in the Netherlands is examined by testing whether (a) the public oversight body can differentiate audit quality in its first-time inspection round, and (b) audit quality improves after the first-time inspection round. Specifically, the study focuses on whether there is an association between the outcome of the first-time inspections (i.e., 'material findings' or 'no material findings') and the level of earnings quality, and any subsequent change in earnings quality, of companies audited by the inspected audit firms. In additional analyses, it is examined what types of deficiencies are most able to differentiate audit quality. Furthermore, by means of comparison, prior peer review outcomes of audit firms are examined whether these appropriately distinguish and improve audit quality. Data on inspection outcomes, types of deficiencies, and peer review outcomes are obtained from the proprietary files of the Dutch public oversight body. These data are complemented with public financial statement data.

Chapter 3 presents the second study relating to auditor independence and audit quality. More specifically, the association is examined between the existence of an audit firm-client business relationship and audit quality, inferred from both audit fees and earnings quality. In 2011, the Dutch public oversight body performed an exploratory review regarding the independence of audit firms with a license to perform audits for PIEs. The public report that was published after this review shows, amongst other things, that audit firms maintain business relationships with various audit clients. The identified business relationships can be characterized as business relationships in which the audit firm purchases goods or services from an audit client. The existence of such a business relationship may constitute an independence threat for which the Code of Ethics (IESBA 2013) prescribes the application of the conceptual framework: audit firms and auditors 
must identify risks to their independence, evaluate those risks, and take adequate measures to safeguard their independence. The purpose of this study is to examine the effectiveness of these independence requirements by assessing how audit firms adjust their efforts and/or risk premiums when they maintain a business relationship with an audit client. Data on business relationships and audit fees are obtained from the proprietary files of the Dutch public oversight body, and complemented with public financial statement data.

Chapter 4 presents the third study which is focused on audit quality indicators. More specifically, the association is examined between audit firm governance characteristics and three firm-level output measures of audit quality: (a) stakeholder dissatisfaction (e.g., (disciplinary court) complaints, claims, and legal proceedings); (b) regulatory attention (e.g., inspections and sanctions by the public oversight body); and (c) audit market exits. The purpose of this study is to identify audit quality indicators and increase the understanding of audit firms and their governance. It is tested whether audit firms with stronger governance mechanisms in place are less likely to be confronted with stakeholder dissatisfaction, trigger regulatory attention, or exit the audit market. Audit firm governance is operationalized by means of organizational variables and variables relating to the quality control system in place. Data on both the audit firm governance characteristics and the firm-level audit quality output measures are obtained from the proprietary files of the Dutch public oversight body.

Chapter 5 of this dissertation summarizes the main results of these three studies and discusses their contributions, limitations, and implications.

\subsection{Outline of the Dissertation}

The following three chapters contain the three previously introduced studies of this dissertation. Chapter 2 presents the first study on public oversight, based on evidence from first-time inspections of Dutch audit firms. Chapter 3 presents the second study on business relationships and auditor independence. Chapter 4 presents the third study on audit firm governance and audit quality indicators. While these three studies are presented in chronological order of the regulatory developments they primarily relate to, they are autonomously structured and can be read separately or in different order than presented in this dissertation. Chapter 5 presents a summary of the main results of the three studies, a discussion of the main limitations, contributions and implications, and it provides suggestions for future research. 


\section{Public Oversight and Audit Quality:}

\section{Evidence from First-Time Inspections of Dutch}

\section{Audit Firms ${ }^{1}$}

\footnotetext{
1 This paper is co-authored with Katrien Van de Poel (University of Antwerp) and Ann Vanstraelen (Maastricht University). We are grateful for the helpful comments and suggestions received from Jean C. Bedard, Kathleen Bentley, Stefano Cascino, Teija Laitinen, Kai-Uwe Marten, Steven Maijoor, Jeffrey Pittman, Annelies Renders, Caren Schelleman, Per Tronnes, Patrick Vorst, participants at the 2009 EARNet Symposium in Valencia, the 2010 AAA Auditing Section Midyear Meeting in San Diego, the 2010 European Accounting Association Conference in Istanbul, and a workshop at the Netherlands Authority for the Financial Markets. We thank Miguel Voigt and Mona Offermanns for data assistance.
} 


\begin{abstract}
Despite the significant amount of resources spent on public oversight of the auditing profession, there is little evidence on whether a public oversight body can differentiate audit quality. We address this question using proprietary data on first-time inspections by the Dutch public oversight body. Further, we examine whether audit quality improves after the first inspection round. We show that client companies of an audit firm with material findings in its inspection report have lower earnings quality than companies audited by a firm without material findings. These results hold for audit firms with and without public interest entities (PIEs), except for the group of smallest non-PIE audit firms. We find that deficiencies related to engagement performance and documentation, independence and quality reviews are most able to distinguish audit quality. In contrast to U.S. evidence, we do not find support for an improvement in audit quality after the first inspection round. Our study contributes to the emerging literature on the effectiveness of oversight of audit firms, and is one of the first that relates to a non-U.S. setting.
\end{abstract}




\subsection{Introduction}

One of the most fundamental changes in the history of the auditing profession is the replacement of self-regulatory peer reviews by independent public oversight. It was triggered by a number of high-profile corporate failures and concerns that the selfregulated peer review system lacked credibility and failed to assure audit quality (Fogarty 1996). Independent public oversight was proposed instead as an alternative way of organizing audit oversight with the goal to restore confidence in and safeguard the public function of the auditing profession. Oversight authorities supervise the compliance with rules and regulations, perform inspections and investigations in order to identify insufficient audit quality, and impose sanctions accordingly. Carcello et al. (2011) argue that independent public oversight has some structural advantages over self-regulatory peer reviews: inspectors are expected to be more independent and more objective, having more inspection expertise, and devoting more attention and resources to the supervision process. DeFond (2010), however, argues that the shift from a peer review system to independent public oversight may be associated with a trade-off of expertise for independence. Given these opposing arguments, and the significant amount of resources that is spent on public oversight, its functioning and ability to appropriately distinguish and improve audit quality becomes an important empirical question, which we address in this paper.

While there is an emerging literature in the U.S. on the impact of PCAOB inspections on audit firm behavior and potential market consequences (e.g., Nagy 2014; DeFond and Lennox 2011; Lennox and Pittman 2010a), studies addressing this basic empirical question are surprisingly limited. Research outside the U.S. on public oversight is even more scant despite the fact that many national oversight bodies have been operational since a number of years. One of the main impediments is the lack of public data on public oversight bodies' findings (Maijoor and Vanstraelen 2012). In this study, we make use of proprietary access to first-time inspection outcomes on audit firms of the Dutch public oversight body (AFM), which were used for granting audit firm licenses. First-time inspection outcomes are particularly interesting to examine the suggested trade-off of expertise for independence.

The purpose of the study is to examine the effectiveness of the Dutch public oversight body by testing (a) its ability to discriminate audit quality for the population of audit firms requiring a license, and (b) whether audit quality improves after the firstinspection round. In additional analyses, we examine what type of deficiencies are most able to differentiate audit quality. Our study relates to both publicly listed and private companies since independent public oversight in the Netherlands entails the entire statutory audit market comprising both type of companies. Furthermore, by means of comparison, we examine whether the prior peer review outcomes of audit firms appropriately distinguished and improved audit quality. Collectively, this allows to furthercomplementcurrent dataandinsightsfrom theU.S. onauditqualitydifferentiation by independent public oversight bodies. Of note, in contrast to the PCAOB, the AFM did 
not initially target low-quality audit firms which would raise concern on the representativeness of the dataset to address our empirical questions (DeFond 2010). Rather, it relates to all audit firms with at least 10 audit clients.

Based on a sample of first-time inspection reports of 51 audit firms covering over 85 percent of the statutory audit market in the Netherlands, and relating to 6,609 client company-year observations over the years 2005-2008, we find that companies audited by firms with material findings in its first-time inspection by the public oversight body have lower earnings quality than companies audited by audit firms without material findings. This finding holds for audit firms with and without PIE (public interest entities) clients $^{2}$, except for the group of smallest non-PIE audit firms. However, our evidence does not provide support for an improvement in audit quality after the first inspection round. This finding is in contrast to U.S. evidence suggesting an improvement in audit quality after PCAOB inspections (Carcello et al. 2011; Gramling et al. 2011). Further, we find that the types of deficiencies identified by the public oversight body that are most able to distinguish audit quality are related to the performance and documentation of audit engagements, independence, and quality reviews. These findings contribute to existing U.S. research on public oversight for which the public portion of the PCAOB inspection report typically does not disclose quality control problems. Furthermore, it is consistent with the emphasis that is currently placed by standard setters and regulators (e.g., EC, IAASB, PCAOB) on audit firm governance, quality control, and auditor independence to safeguard audit quality. Finally, we find no support for an association between the prior peer review outcomes of audit firms and earnings quality of client companies. We also fail to find support that audit quality improved after peer review outcomes.

The contribution of our study is two-fold. First, we contribute to the limited literature on the effectiveness of an independent public oversight body in differentiating and improving audit quality. Second, we contribute to the literature by examining what types of deficiencies in audit firms identified by the public oversight body are most able to differentiate audit quality. Overall, our findings contribute to the emerging literature on the inspection process of public oversight bodies, and we are one of the first to examine this in a E.U. setting.

The remainder of this paper is organized as follows. In the next section, we describe the regulatory changes to the institutions responsible for monitoring audit firms in the U.S., Europe, and the Netherlands in particular. Further, we give an overview of the insights from prior research studying the effectiveness of self-regulation and independent oversight as mechanisms for audit quality monitoring. In the third section, we develop our hypotheses. Our research design and sample are described in the fourth section. The results of our study are presented in the fifth section. In the sixth section, we perform an additional analysis using prior peer review data. Finally, we provide a discussion and conclusion of our findings in the final section.

2 Public interest entities are stock listed companies, insurance companies, and credit institutions (banks). 


\subsection{Background}

\subsubsection{Regulation of the Auditing Profession}

One of the legislative responses to the loss of public confidence in the audit process following the high-profile scandals in the U.S. and Europe in the early years 2000 was to put an end to the era of self-regulation of the auditing profession. With the implementation of the Sarbanes-Oxley Act in the U.S., all accounting firms that issue an audit report for an SEC-reporting company or substantially participate in the audit are required since 2004 to be registered with the PCAOB, performing periodicindependent inspections of these firms. Other countries around the world (e.g., Australia, Canada and Japan) have followed the U.S. example of installing independent public oversight.

In Europe, the revised $8^{\text {th }}$ E.U. Directive (2006) put an end to self-regulation of the auditing profession in all E.U. member states, and member states were given two years (up to June 2008) to implement the provisions of the new Directive. European public oversight authorities now have ultimate responsibility for approval and registration of audit firms, quality control of audit firms and auditors, continuous education of auditors and investigative and disciplinary actions against audit firms.

The Netherlands was one of the first European countries to set up an independent public oversight system for all audit firms performing statutory audits. ${ }^{3}$ Since October 2006, public oversight of the auditing profession in the Netherlands is regulated by the Audit Firms Supervision Act (AFS Act 2006). The AFS Act delegates the oversight of audit firms performing statutory audits to the Netherlands Authority for the Financial Markets (AFM), an independent authority which reports to the Dutch Ministry of Finance. Under the AFS Act, all audit firms need to apply for a license granted by the AFM to perform statutory audits in the Netherlands, and become subject to continuous inspections. The AFS Act contains quality control requirements for audit firms that are primarily based on the 'International Standard on Quality Control 1' (IAASB 2009b). The applicable quality control requirements at firm and engagement level are summarized in Exhibit 1 . All the inspections conducted in the license approval process are carried out by non-practicing staff employed by the AFM. The first-time inspections consisted of desktop reviews and on-site inspections of audit firms with at least 10 audit clients. The purpose of these inspections was to verify the audit firm's compliance with all legal requirements and professional standards, and to identify any material deficiencies in the audit firm's quality control system and/or audit files on client engagements. The inspections had two

\footnotetext{
A statutory audit is defined in the Audit Firms Supervision Act (AFS Act) as "an audit of the financial accounts of an enterprise or institution serving a social purpose, that has been made mandatory by or pursuant to the statutory provisions stated in the appendix to this Act". This includes the audits of all public companies and private companies that meet two out of the following three criteria: a) turnover over $€ 7.3$ million, b) total assets over $€ 3.65$ million, and c) number of employees over 50 (applicable to the time period studied in this paper). Furthermore, this includes the audits of several financial enterprises, municipalities, provinces, and certain governmental agencies.
} 
possible initial overall outcomes: 'no material findings' and 'material findings'. These initial outcomes were communicated with the respective audit firms at the end of the on-site inspection before the final decision on the license application was made. In case of no material findings, the audit firm was considered of sufficient quality and it was communicated that a license to perform statutory audits would be granted at a later date. In case of material findings, the audit firm was considered to be of low(er) quality. If the deficiencies were considered to be correctable within the short term, the audit firm was given time to make the necessary improvements. If the improvements subsequently proved to be satisfactory, the audit firm would be granted a license. If the deficiencies were not considered to be correctable within the short term, the license application would be rejected. ${ }^{4}$

\subsubsection{Prior Literature 5}

Studies performed in the U.S. show that peer review opinions are related to perceived and actual audit quality but also that not all peer reviews are objective and that some firms were able to control peer review outcomes by choosing 'friendly' reviewers (e.g., Hilary and Lennox 2005; Casterella et al. 2009; Anantharaman 2012).

Similar to the work of Hilary and Lennox (2005) on the credibility of peer reviews, Lennox and Pittman (2010a) test whether the inspection reports issued by the PCAOB provide credible information to clients about audit firm quality, and find that audit firms' market shares appear to be insensitive to the content of the PCAOB reports. At the same time, DeFond and Lennox (2011) show that the PCAOB inspection regime incentivized small low quality audit firms to exit the public audit firm market. Abbott et al. (2013) find that the clients of GAAP-deficient, triennially inspected auditors are more likely to dismiss these auditors in favor of triennially inspected auditors that are not GAAP-deficient. Since the PCAOB recently started to disclose quality control deficiencies which were not appropriately addressed within a year, Nagy (2014) finds that audit firms do lose market share following the public disclosure of quality control criticisms. Similarly, Dee et al. (2011) show a negative market reaction to PCAOB sanctions imposed upon a Big 4 audit firm for which quality control problems were disclosed.

Research on the empirical question whether the public oversight body is able to appropriately distinguish and improve audit quality is limited and focused on the PCAOB. In a recent working paper, Aobdia (2015) relates PCAOB engagement specific deficiencies to commonly used measures of audit quality in the literature, and finds that several of these measures are predictive of audit deficiencies. Gunny and Zhang (2013)

4 Most audit firms make use of the opportunity to appeal the decision to reject a license. If the audit firm makes further improvements during this (legal) process, the AFM is bound to take these improvements into consideration and grant a license if the audit firm has demonstrated that it complies with all relevant requirements.

5 For an overview of the literature on public oversight, we refer to Offermanns and Vanstraelen (2014). 


\section{Exhibit 1}

\section{Description of Quality Control Requirements}

\begin{abstract}
Audit Firm Level
General policies
\end{abstract} and procedures

(Control) structure

Good repute

Integrity

Independence

Client account records

Acceptance and continuance of audit engagements

(Human) resources

Consultation
Audit firms are required to design a system of quality control to provide the firm with reasonable assurance that the firm and its personnel comply with professional standards and regulatory and legal requirements, and that reports issued by the firm or engagement partners are appropriate in the circumstances. The system of quality control is usually laid down in the audit firm's quality manual, which consists of policies, procedures, descriptions, and standards.

A majority of the voting rights in the audit firm shall be held by and a majority of the members of the administrative or management body of the audit firm must be persons that satisfy the requirements in regard to the competence of auditors. Furthermore, the formal or actual control structure of the audit firm shall not represent an obstacle for effective oversight.

All members of the audit firm's administrative and/or management body (policymakers and co-policymakers) should be of good repute. (Since none of the audit firms included in our sample had material findings regarding the good repute of their (co-)policymakers, the 'good repute' requirement is left out of the further analyses).

The audit firm should establish integrity policies and procedures designed to prevent the involvement of the audit firm, the auditors or other employees of the audit firm in criminal offences and infringements of the law, and relationships with clients that could be detrimental to confidence in the audit firm or in the financial markets.

If an audit firm or any other part of the network maintains relationships with an audit client or a third party affiliated to that audit client that could represent a threat to the independence of the audit firm vis-à-vis either the audit client or the third party, the audit firm must apply safeguards to ensure its independence by eliminating or reducing such a threat. If such safeguards are not feasible, the audit firm shall not accept the assignment, or shall terminate the assignment.

An audit firm shall maintain a systematic, accessible and up-to-date set of client account records, which include per audit client the name and full business address of the audit client, whether the audit client is a public interest entity, the name of the responsible auditor, and the fees charged for the statutory audit and the fees charged for other services rendered in any financial year.

Before accepting or continuing an assignment for an audit, an audit firm must determine whether the firm and its auditors comply with all applicable requirements, whether it has the specialist employees, time and resources required to perform the audit in an appropriate manner, and the integrity of the audit client.

An audit firm shall provide the auditor with such time, resources and personnel as he needs to carry out his task in an appropriate manner.

An audit firm will ensure that, where necessary for the proper conduct of an audit, the responsible auditor consults subject-matter specialists. The audit firm will ensure that the responsible auditor documents the subject and conclusions of such a consultation. 


Engagement
quality control
review

Monitoring and internal inspections

Duty of care

\begin{abstract}
The firm should establish policies and procedures requiring, for all audits for PIEs and for all other audits that meet the criteria as set out by the firm, an engagement quality control review that provides an objective evaluation of the significant judgments made by the engagement team and the conclusions reached in formulating the audit report. The engagement quality control review should be performed by a certified auditor and be completed before the audit report is issued.
\end{abstract}

An audit firm shall ensure compliance with its system of quality control and it will carry out an annual evaluation of its system of quality control, including a periodic inspection of a selection of completed engagements. Audit firms that perform audits for public interest entities must appoint a compliance officer.

The audit firm shall ensure that its auditors comply with the requirements in regard to their competence, independence, objectivity, integrity, and reporting of reasonable assumptions of fraud.

AuditEngagement Level

Professional

The auditor should plan and perform an audit with an attitude of professional skepticism skepticism recognizing that circumstances may exist that cause the financial statements to be materially misstated.

Sufficient appropriate The auditor should obtain sufficient appropriate audit evidence to be able to audit evidence draw reasonable conclusions on which to base the audit opinion.

Audit trail

The audit files should provide an accurate and coherent reproduction of the various phases of the audit process: the engagement acceptance or continuance, the audit approach, the audit plan, the risk analysis, the performance of audit procedures, the findings, the conclusions, and the audit opinion.

Fraud

In planning and performing the audit to reduce audit risk to an acceptably low level, the auditor should consider the risks of material misstatements in the financial statements due to fraud. An auditor who, during the performance of an audit, is given access to data or information which justifies the reasonable assumption of fraud of substantial importance in regard to the financial accounts of the audit client, will report this assumption to an investigating official.

Notes: The quality control requirements in this exhibit are derived from the legal requirements in the Audit Firms Supervision Act (Articles 14-31), the Decree on the Supervision of Audit Firms (Articles 8-38), and the International Standards on Auditing (i.e., ISA 200, 230, 240, and 500). 
provide some empirical support that $\mathrm{PCAOB}$ reports are able to discriminate audit quality for triennially inspected audit firms, but fail to find evidence that PCAOB inspection reports distinguish audit quality for annually inspected audit firms. Carcello et al. (2011) provide preliminary evidence that the quality of audits provided by Big 4 firms improved after the first and second inspection rounds. Gramling et al. (2011) find that there is a higher likelihood that triennially inspected audit firms with PCAOB audit deficiencies will issue a going-concern opinion to a financially distressed client company subsequent to their inspection than before.

Apart from De Fuentes et al. (2010) showing that sanctioned auditors by the Spanish Institute of Accounting and Auditing exhibit lower average audit quality than non-sanctioned auditors, there is very limited insight on the effectiveness of peer reviews and independent public oversight outside the U.S. The purpose of this paper is to contribute to the emerging literature on the effectiveness of public oversight by providing insights from a non-U.S. setting.

\subsection{Development of Hypothesis}

To assure high quality inspections, inspectors must have both the expertise to capture actual audit quality and the necessary independence to report the outcome of their inspections objectively (FEE 2006). The long-standing debate in the economics literature between self-regulation and government regulation (Peltzman 1976; Stigler 1971) is characterized by an alleged trade-off of expertise for independence associated with the switch from peer reviews to independent public inspections. Since independent full-time inspectors have no personal or employment relationship with the audit firms they inspect, concerns on inspectors' independence are mitigated. It can, however, be very challenging for full-time inspectors of an oversight body to have or maintain their knowledge of professional developments and their understanding of day-to-day business and audit techniques. Therefore, the expertise of the inspectors performing the quality reviews is of utmost importance to obtain high quality inspections. To assure the technical competence of the Dutch AFM inspectors, all employed inspectors have on average 10 to 15 years of relevant experience in the auditing profession. Furthermore, before starting the license application inspections, the inspectors have received extensive training to ensure their knowledge of recent regulatory and professional developments. We therefore expect the public oversight inspectors to have both the expertise and the necessary independence to distinguish between high and low quality audit firms in the first-time inspections.

While the public oversight body communicates inspection outcomes at audit firm level, we formulate our hypotheses and measure audit quality at the client-firm level for a number of reasons. First, GAAP and GAAS deficiencies identified by the public oversight body at the audit engagement level will lead to material findings at the audit firm level. Second, as Carcello et al. (2011) argue and as outlined in the quality control requirements 
(see Exhibit 1), the inspection process is expected to identify deficiencies in how firms plan and perform audits at the audit engagement level. Third, we follow prior studies on the effectiveness of PCAOB audit firm inspection reports, measuring audit quality at client firm level (e.g., Carcello et al. 2011; Gramling et al. 2011; Gunny and Zhang 2013; Aobdia 2015).

Hence, we test the following hypothesis:

H1: Audit quality is lower for client companies of audit firms with material findings in the first-time inspections compared to client companies of audit firms without material findings in the first-time inspections.

Being able to differentiate between audit firms with high and low audit quality is the basic premise but only one aspect of the effectiveness of a public oversight body. To be able to subsequently improve audit quality is arguably even more important. In line with Carcello et al. (2011), we would expect that the detailed inspections and reported findings offer possibilities to audit firms to improve audit quality subsequent to these inspections by taking corrective actions. Furthermore, audit firms to which the public oversight body communicated material findings are likely to have stronger incentives to take corrective actions compared to audit firms without material findings. Hence, we would expect that the improvement in audit quality will be more pronounced for audit firms with deficient inspection reports after the first-time inspections, and formulate the following hypotheses:

H2a: Audit quality for client companies improves in the post-inspection period compared to the pre-inspection period.

H2b: Audit quality improves more for client companies of audit firms with material findings than for client companies of audit firms without material findings in the post-inspection period compared to the pre-inspection period.

However, these expectations may prove to be premature in the Dutch setting. The initial first-time inspection outcomes were only communicated confidentially to the respective audit firms and no public audit firm-specific reports were published. Furthermore, most audit firms with a substantive audit practice eventually received a license. Both factors may have limited the sense of urgency to improve as perceived by the audit firms involved. In fact, subsequent generic inspection reports published by the AFM have shown a persistent insufficient audit quality in the audit files reviewed. ${ }^{6}$

\footnotetext{
In 2010 the AFM published a report regarding the audit quality and quality control monitoring of Big 4 audit firms. The AFM concluded that approximately 52 percent of the 46 statutory audits for the financial year 2008 it reviewed in the course of the inspection to be of insufficient quality (AFM 2010). In 2013, the AFM concluded that approximately 74 percent of the 47 statutory audits for the financial years 2010-2011 it reviewed in the course of the inspection of nine other audit firms with PIE clients to be of insufficient quality (AFM 2013a). Also in 2013, the AFM concluded that approximately 80 percent of the 110 statutory audits for the financial year 2012 it reviewed in the course of the inspection of 50 audit firms with only non-PIE clients to be of insufficient quality (AFM 2013b). In 2014, the AFM published a report with the conclusion that statutory audits performed by the Big 4 audit firms were still too often of insufficient quality (i.e., 45 percent of 40 reviewed audits) and that quality improvement measures taken in the prior period had proven ineffective (AFM 2014).
} 


\subsection{Research design}

\subsubsection{Empirical Model}

\section{Dependent Variable}

As a proxy for audit quality, we use abnormal accruals. Earnings quality measures, such as abnormal accruals, are designed to capture financial reporting quality which should arguably be the ultimate goal of the auditor to improve (DeFond and Zhang 2014). Furthermore, the descriptive analysis of Roybark (2009) on the type of deficiencies identified by the PCAOB documents that common deficiencies relate to accounting for inventory and/or cost of sales, cash and cash equivalents and marketable securities, revenue recognition and accounts receivable. All of these accounts affect the magnitude of accruals. This is also reflected in the findings of Aobdia (2015) showing that abnormal accruals at client-firm level are predictive of engagement-specific deficiencies identified by the PCAOB. As larger accruals imply lower earnings quality, a high quality audit will be more effective at constraining opportunistic reporting by managers resulting in lower levels of abnormal accruals (Francis et al. 2009).

To measure abnormal accruals, we use the performance-adjusted cross-sectional modified Jones (1991) model as described by Dechow et al. (1995) and Kothari et al. (2005), and first estimate the following OLS regression: ${ }^{7}$

$$
T A_{t}=\alpha_{0}+\alpha_{1}\left(1 / \operatorname{ASSETS}_{t-1}\right)+\alpha_{2}\left(\Delta R E V_{t}-\Delta A R_{t}\right)+\alpha_{3} P P E_{t}+\varepsilon
$$

All the variables used in various tests are summarized in Table 1.

We estimate equation (1) by year and by three-, two-, or one-digit SIC codes depending on whether there are at least 10 companies in each SIC group. ${ }^{8}$ A company's unadjusted abnormal accruals are set equal to the difference between total accruals and the fitted normal accruals estimated by the appropriate residuals from equation (1). Subsequently, we adjust abnormal accruals for performance as advised by Kothari et al. (2005). To this end, we rank companies within each industry-year group into ten groups based on their return-on-assets (ROA). Performance-adjusted abnormal total accruals (ATA) are the difference between the sample company's 'unadjusted abnormal accruals' and the median abnormal accruals for companies in the same industry-year-ROA decile. We analyze the absolute value of $A T A$, and income-increasing $(A T A>0)$ and income-decreasing

\footnotetext{
Observations for which any value of the variables in equation (1) is above the 0.99 value or below the 0.01 value of all companies are excluded from the calculation of parameter values for equation (1) to mitigate the effect of these extreme values on the calculation of 'expected' accruals. However, these companies are included in the final sample, after winsorizing extreme values.

8 We have 8 industries at the 1-digit SIC level for each year in our sample; at the 2-digit SIC level, we have 39 industries in year 2005, 38 in year 2006, 36 in year 2007 and 33 in year 2008; at the 3-digit SIC level, we have 56 industries in the years 2005 and 2006, 46 in the year 2007 and 40 in the year 2008.
} 


\section{Table 1}

\section{Variable Definitions (In Alphabetical Order)}

\begin{tabular}{|c|c|}
\hline Variable & Definition \\
\hline$\% A Q \_M A N$ & An audit firm's percentage of managers with an audit qualification. \\
\hline$\triangle A R$ & $\begin{array}{l}\text { A company's change in accounts receivable from year } t-1 \text { to year } t \text {, scaled } \\
\text { by lagged total assets. }\end{array}$ \\
\hline$\triangle R E V$ & $\begin{array}{l}\text { A company's change in sales from year } \mathrm{t}-1 \text { to year } \mathrm{t} \text {, scaled by lagged total } \\
\text { assets. }\end{array}$ \\
\hline$|A T A|$ & The absolute value of ATA. \\
\hline ASSETS & A company's total assets in thousand euros. \\
\hline ATA & $\begin{array}{l}\text { A company's abnormal accruals, calculated using a variant of the } \\
\text { performance-adjusted cross-sectional modified Jones (1991) model as } \\
\text { described by Dechow et al. (1995) and Kothari et al. (2005) (see equation } \\
1 \text { for details). }\end{array}$ \\
\hline AUDITORS & $\begin{array}{l}\text { An audit firm's number of auditors appointed in charge of statutory } \\
\text { audits. }\end{array}$ \\
\hline AV_CLIENTS & $\begin{array}{l}\text { An audit firm's average number of companies audited by an individual } \\
\text { auditor. }\end{array}$ \\
\hline AV_FEES & $\begin{array}{l}\text { An audit firm's average total audit fees invoiced for performing statutory } \\
\text { audits. }\end{array}$ \\
\hline$A W C A$ & $\begin{array}{l}\text { A company's abnormal working capital accruals in year t, calculated as } \\
\text { realized working capital minus 'expected' working capital, where expected } \\
\text { working capital is assumed to be a fixed proportion of sales (Dechow et al. } \\
\text { 1998; DeFond and Park 2001). }\end{array}$ \\
\hline CFO & $\begin{array}{l}\text { A company's cash flows from operations scaled by total assets (absolute } \\
\text { value in regressions on absolute abnormal accruals and signed value in } \\
\text { regressions on income-increasing or income-decreasing (i.e., signed) } \\
\text { abnormal accruals). }\end{array}$ \\
\hline CLIENTS & An audit firm's total number of companies audited. \\
\hline EXCEPT & $\begin{array}{l}\text { An indicator variable equal to } 1 \text { if the material findings involve exceptional } \\
\text { issues in audits, e.g., consultations or fraud issues; otherwise } 0 .\end{array}$ \\
\hline FEES & An audit firm's total audit fees invoiced for performing statutory audits. \\
\hline INDEP & $\begin{array}{l}\text { An indicator variable equal to } 1 \text { if the material findings involve the audit } \\
\text { firm's independence policies and procedures or the auditors' application } \\
\text { of professional scepticism; otherwise } 0 \text {. }\end{array}$ \\
\hline INDUSTRY & $\begin{array}{l}\text { Vector of industry dummies (SIC 100-199: Mining and construction; SIC } \\
\text { 200-399: Manufacturing; SIC 400-490: Transportation, Communication, } \\
\text { Electric, Gas, and Sanitary Services, SIC 500-599: Wholesale trade). SIC } \\
700-899 \text { (Services) is the industry of reference. }\end{array}$ \\
\hline$L E V$ & A company's total liabilities scaled by total assets. \\
\hline LISTED & $\begin{array}{l}\text { An indicator variable equal to } 1 \text { if the company is publicly quoted; } \\
\text { otherwise } 0 \text {. }\end{array}$ \\
\hline LNASSETS & The natural logarithm of a company's total assets in thousand euros. \\
\hline LOSS & $\begin{array}{l}\text { An indicator variable equal to } 1 \text { if the company reports a loss in the } \\
\text { current year; otherwise } 0 \text {. }\end{array}$ \\
\hline MANAGERS & $\begin{array}{l}\text { An audit firm's number of individuals that (co-)determine the day-to-day } \\
\text { policies of the audit firm. }\end{array}$ \\
\hline
\end{tabular}


Table 1 - continued

$M F$

$M F \_P R$

ORG_STRUCT

PERF_DOC

PIE

POST_INSP

POST_REV

PPE_GROWTH

PPE

QC_SYSTEM

REVIEW

$R O A$

SALES_GROWTH

SALESVOL

SALES

TA

WC

WSUM

YEAR
An indicator variable equal to 1 if the Dutch public oversight body (AFM) had material findings in its initial inspections of the company's audit firm; otherwise 0 .

An indicator variable equal to 1 if the Dutch peer review team had material findings in its review; otherwise 0 .

An indicator variable equal to 1 if the material findings involve the audit firm's organizational structure and (human) resource allocations; otherwise 0 .

An indicator variable equal to 1 if the material findings involve the audit firm's performance and documentation of statutory audits; otherwise 0 .

An indicator variable equal to 1 if the company's audit firm has applied for a PIE license to be allowed to audit public interest entities; otherwise 0 .

An indicator variable equal to 1 for the financial years audited after the AFM inspections, i.e., for the years 2007 and 2008; otherwise 0.

An indicator variable equal to 1 for the financial years audited after the peer reviews inspections, i.e., for the years 2005 and 2006; otherwise 0.

A company's one-year growth in gross property, plant, and equipment from year $\mathrm{t}-1$ to year $\mathrm{t}$.

A company's gross property, plant, and equipment, scaled by lagged total assets.

An indicator variable equal to 1 if the material findings involve the audit firm's design of its quality control system (e.g., policies and procedures); otherwise 0 .

An indicator variable equal to 1 if the material findings involve the audit firm's engagement quality reviews or monitoring and internal inspections; otherwise 0 .

A company's return on assets, defined as net income scaled by lagged total assets.

A company's one-year growth in sales from year t- 1 to year $t$.

Sales volatility, defined as the standard deviation of the change in a company's sales, scaled by average assets in the preceding three years.

A company's sales.

Total accruals, defined as a company's change in non-cash current assets minus the change in current liabilities excluding the current portion of long-term debt, minus depreciation and amortization, scaled by lagged total assets.

Non-cash working capital, defined as a company's (current assets - cash and short-term investments) - (current liabilities - short-term debt).

The number of different types of deficiencies identified during the inspection of a company's audit firm, ranging from 0 to 6 .

Vector of year dummies. 
abnormal accruals $(A T A<0)$ separately, since ex ante it is not clear what the direction of earnings management is, given that we have both listed and private companies in our sample. Hence, companies are expected to exhibit both income-increasing and incomedecreasing accruals (Warfield et al. 1995).

\section{Independent Variables}

Test variables. The independent variable of interest for testing $\mathrm{H} 1$ is the Dutch public oversight body's first-time inspection outcome ('material findings' or 'no material findings') concerning the company's audit firm $(M F)$. The indicator variable $M F$ is given a value of 1 if material findings were identified at the company's audit firm by the AFM and 0 if no material findings were identified. First-time inspection outcomes are collected from the files of the AFM. For testing $\mathrm{H} 2 \mathrm{a}$ and $\mathrm{H} 2 \mathrm{~b}$, we additionally construct an indicator variable POST_INSP equal to 1 if the observation is post-inspection, and 0 if it is preinspection.

Control variables. Tocontrol for differences in earnings managementincentives and company characteristics that are associated with earnings quality, we include the following control variables found in prior studies to be associated with abnormal accruals (e.g., Dechow and Dichev 2002; Francis et al. 2013; Hribar and Nichols 2007; Young 1999): LNASSETS, to control for company size, $L E V$, to control for a company's leverage, CFO and LOSS, to control for a company's performance (measured as cash flow from operations scaled by total assets and by an indicator variable equal to 1 if the company's net income is negative, and otherwise 0, respectively), SALES_GROWTH, PPE_GROWTH, and SALESVOL, to control for a company's natural volatility of its accruals (measured as the one-year growth in sales and gross property, plant and equipment, and the standard deviation of the change in a company's sales, scaled by average assets in the preceding three years, respectively), LISTED, to control for a company's stock listing, and YEAR and INDUSTRY dummies. ${ }^{9}$

Hence our empirical model for testing $\mathrm{H} 1$ formally look as follows: ${ }^{10}$

$$
\begin{aligned}
& \left|A T A_{t}\right|, A T A_{t}>0 \text { or } A T A_{t}<0=\beta_{0}+\beta_{1} M F_{t}+\beta_{2} L_{N A S S E T S}+\beta_{3} L E V_{t}+\beta_{4} C F O_{t} \\
& +\beta_{5} S A L E S \_G R O W T H_{t}+\beta_{6} \text { PPE_GROWTH } H_{t}+\beta_{7} S A L E S V O L_{t}+\beta_{8} L_{\text {LOSS }} \\
& +\beta_{9} \text { LISTED }_{t}+\text { YEAR/INDUSTRY fixed effects }+\varepsilon
\end{aligned}
$$

\footnotetext{
We note that we do not include a Big 4 audit dummy in our main model since Dutch Big 4 audit firms cannot be considered a homogenous group with regard to audit quality. From press releases (available on the AFM website, www.afm.nl), it becomes clear that the AFM has issued reports on the inspections and investigations of all Big 4 audit firms, and issued administrative fines to three Big 4 firms, regarding non-compliance with the Dutch audit firms supervision act in the period 2007 to 2009.

10 Observations for which any value of the variables (dependent, test, and control variables) in equations (2) and (3) is above the 0.99 value or below the 0.01 value of all companies are winsorized to mitigate the effect of these extreme values.
} 
The empirical model for testing $\mathrm{H} 2 \mathrm{a}$ and $\mathrm{H} 2 \mathrm{~b}$ is equivalent to equation (2), but includes an indicator variable for the post-inspection period (POST_INSP) and an interaction between this indicator variable and the material findings variable ( $\left.M F{ }^{*} P O S T \_I N S P\right)$, and hence formally look as follows:

$$
\begin{aligned}
\left|A T A_{t}\right|, A T A_{t} & >0 \text { or } A T A_{t}<0=\beta_{0}+\beta_{1} M F_{t}+\beta_{2} M F^{\star} P O S T \_I N S P_{t}+\beta_{3} P O S T_{-} I N S P_{t} \\
& +\beta_{4} L N A S S E T S_{t}+\beta_{5} L E V_{t}+\beta_{6} C F O_{t}+\beta_{7} S A L E S_{-} G R O W T H_{t} \\
& +\beta_{8} P P E_{-} G R O W T H_{t}+\beta_{9} S A L E S V O L_{t}+\beta_{10} L O S S_{t}+\beta_{11} L_{I S T E D} \\
& + \text { INDUSTRY fixed effects }+\varepsilon
\end{aligned}
$$

\subsubsection{Sample}

Our research sample consists of all Dutch companies subject to a statutory audit (excluding financial institutions and insurance companies, SIC 600-699, and utilities companies, SIC 490-499) for which the name of the audit firm is available as well as the required financial statement data for the empirical models using the databases Amadeus, Orbis and Reach. ${ }^{11}$ We further require that each audit firm has company-year observations for the period 2005-2006 as well as for the period 2007-2008.

The AFM inspections with regard to the license applications of Dutch audit firms with clients subject to a statutory audit were conducted from January 2007 to May 2008. These inspections involved the review of most recently finalized audit files, i.e., audits for the financial years 2005 and 2006 . Hence, we consider the earnings quality of companies in the audit firm's client portfolio for the financial years 2005-2006. ${ }^{12}$ In order to examine the change in earnings quality after the initial inspections, we collect data for the financial years 2007-2008.

This results in a sample of 5,152 company-year observations to test the association between the inspection outcome and earnings quality, and a sample of 6,609 company-

11 Amadeus is a pan-European database distributed by Bureau Van Dijk (http://www.bvdep.com) that contains financial information on over 11 million public and private companies in 41 European countries. Orbis contains information on 140 million companies worldwide, with an emphasis on private company information. Since Amadeus and Orbis do not include the name of the audit firm for each financial year separately (they only mention the current audit firm), we collect the names of the responsible audit firms from the database Reach. Reach is a database distributed by Bureau Van Dijk (http://bvdep.com/) that contains financial statement data of Dutch listed and non-listed companies.

12 The financial year (2005 or 2006) for which the most recently finalized audit was available for review, depended on several factors, including the date of inspection and the audit client's size and listing status. For inspections at the end of the 2007-2008 inspection period, 2006 audits were more often reviewed, especially for larger and/or listed companies for which 2006 audits were available at the time of the inspection. Since we do not know exactly for which audit firms only 2006 files were reviewed, for which firms only 2005 files, and for which firms a combination, we consider a two-year period to compute pre-inspection accruals most appropriate. 
year observations to test the change in earnings quality. ${ }^{13}$ These observations involve 3,229 unique companies and 51 unique audit firms, performing in total approximately 85 percent of all statutory audits in the Netherlands. All these audit firms eventually received a license from the AFM to perform statutory audits ${ }^{14}: 50$ at the predetermined license-granting dates of 27 September 2007 (audit firms with PIE clients) or 29 September 2008 (audit firms with only non-PIE clients) and one at a later date. ${ }^{15}$

\subsection{Results}

\subsubsection{Descriptive Statistics and Univariate Results}

\section{Company Characteristics}

Panel A of Table 2 summarizes the descriptive statistics for companies audited by a firm with and without material findings. Since companies may have incentives to under- or over-report earnings, we consider the absolute value of abnormal accruals $(|A T A|)$ to capture the combined effect of income-increasing and income-decreasing earnings management (Warfield et al. 1995). Average $|A T A|(p=0.017)$, and income-increasing abnormal accruals ( $A T A>0, p=0.012)$ are significantly higher for companies audited by a firm with material findings. Companies audited by a firm with material findings further tend to be larger, have relatively lower cash flows from operations, and lower sales volatility than companies audited by an audit firm with no material findings. Further univariate tests (unreported) show that for the audits performed after the initial inspections, i.e., audits for financial years 2007 and 2008, abnormal accruals (absolute, income-increasing, and income-decreasing, respectively) for companies with a 'material findings' auditor are not significantly different from abnormal accruals for companies with a 'no material findings' auditor $(p=0.781,0.467$, and 0.137$)$. When we consider the difference between abnormal accruals in the period before the initial inspections, i.e., audits for financial years 2005 and 2006, and after the initial inspections, i.e., audits for

13 We collected the data in two stages. For the data collection relating to the pre-inspection period, we used a version of the database Reach which was more extensive compared to the version we had available to collect data relating to the post-inspection period. We attempted to further complement this by using the databases Amadeus and Orbis, but continue to have a smaller dataset in the post-inspection period compared to the pre-inspection period due to a recent deteriorated coverage of particular financial statement items used in accruals measurement. We have performed all analyses also on the subsample of companies for which we have at least one observation in the pre-inspection period and one observation in the post-inspection period and the conclusions with regard to Hypothesis $1,2 \mathrm{a}$ and $2 \mathrm{~b}$ remain unchanged.

14 In general, the AFM grants a license within eight weeks after receiving all information necessary for the application. However, with the introduction of the AFS Act in 2006, transitional provisions were put into force allowing the AFM up to two years to perform first-time inspections for all audit firms that were already active in the statutory audit market and in need of a license.

15 We have run the analyses without the audit firm of which the license was initially rejected and this does not change our inferences. 


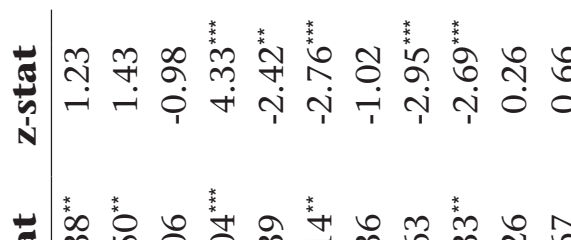

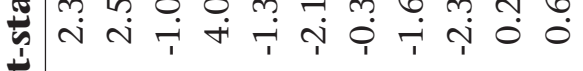

蕉

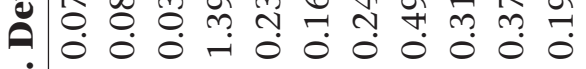

$\dot{\vec{m}}$

ส

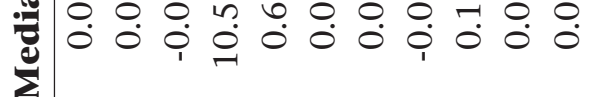

ฐ छั

之إ

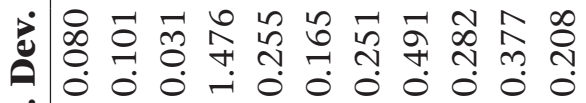

कें

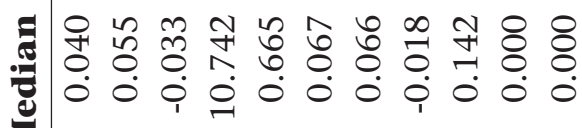

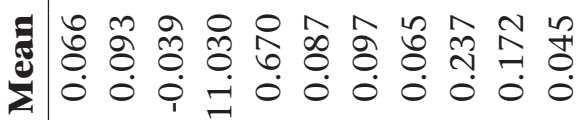

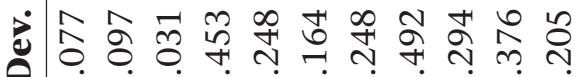

0 : 0 0

ลั

ט

ל.

远 $\mid$

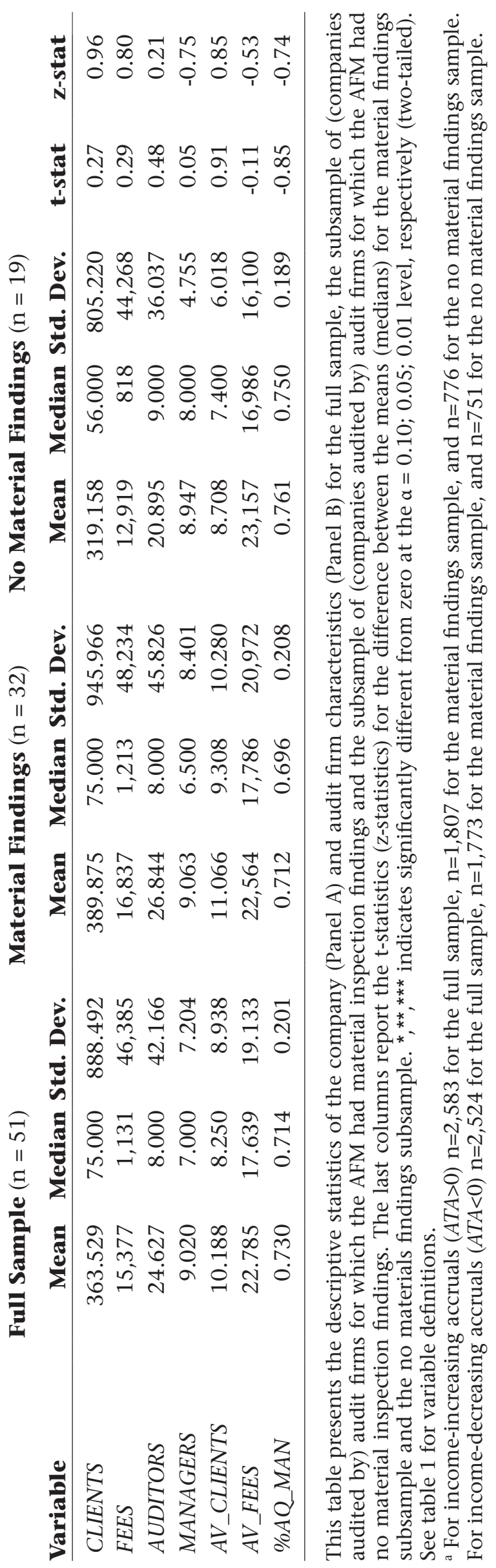




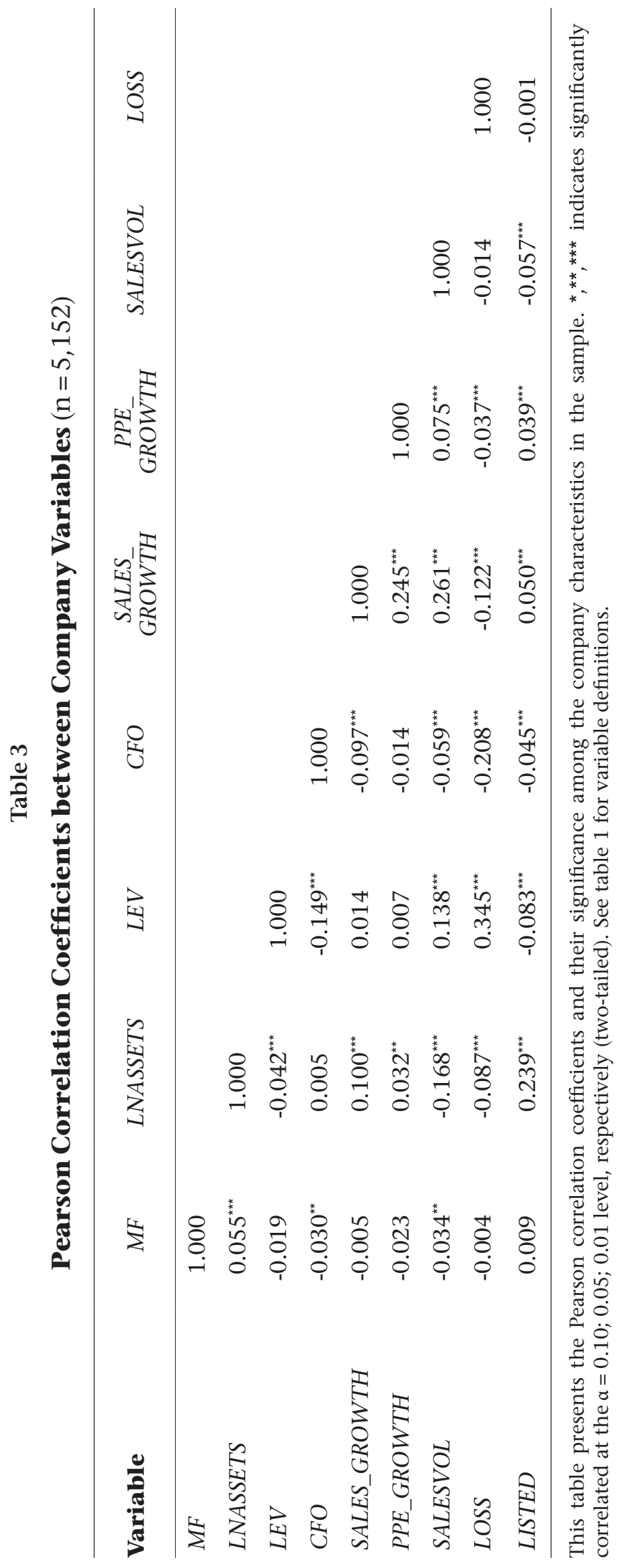


financial years 2007 and 2008, we find that on average absolute abnormal accruals are significantly higher in the post-inspection period $(p=0.000)$, which is driven by more negative income-decreasing abnormal accruals in the post-inspection period $(p=0.000)$, while income-increasing abnormal accruals remain unchanged $(p=0.148)$. These results also hold in the subsamples of companies audited by a firm with and without material findings.

\section{Audit Firm Characteristics}

The companies in our total sample are audited by 51 audit firms that applied for a license to be compliant with the Dutch audit regulation (AFS Act 2006). The first-time inspections of the AFM lead to material findings relating to audit firms' internal quality control systems and/or audit files for 32 of these 51 audit firms ( 63 percent). For 19 audit firms (37 percent) the first-time inspections lead to no material findings.

Panel B of Table 2 summarizes descriptive statistics. In the univariate tests for differences in means (t-statistic) and medians (z-statistics) of the size measures (i.e., number of audit clients, total audit fees, number of auditors, and number of managers) and the ratios (i.e., average number of audit clients per auditor, average audit fee per client, and percentage of managers with an audit qualification) between 'material findings' and 'no material findings' audit firms, we find that there are no significant differences between these audit firms.

\section{Correlations}

Table 3 includes the Pearson correlation coefficients among the company characteristics and the 'material findings' variable $(M F)$. The absence of very high correlations and (untabulated) average VIF values of well below the commonly used threshold of 10 (1.31 for the association analysis and 1.59 for the change analysis), show that the risk of bias in our multivariate analyses due to multicollinearity is minimal (Hair et al. 2006).

\subsubsection{Multivariate Results}

Table 4 reports the multivariate regression results for equations (2) and (3) to test our hypotheses. We tabulate coefficients from OLS-regression models and, in parentheses, $t$-values based on robust standard errors that are clustered by audit firm. ${ }^{16}$

We run the regressions for equations (2) and (3) for the absolute abnormal accruals as well as for the income-increasing and income-decreasing accruals separately. In Table 4, we report a significant positive association between absolute and income-increasing

16 As prior studies using abnormal or discretionary accruals as the dependent variable in their multivariate analyses point out, there may be econometric problems associated with the OLS regression test on the accruals whose distribution is truncated at a certain value (e.g., Gul et al. 2007; Hossain et al. 2011). To mitigate these problems we have conducted Tobit tests as sensitivity analysis. The results of these Tobit tests are similar to those of the OLS regressions as presented in Table 4. 


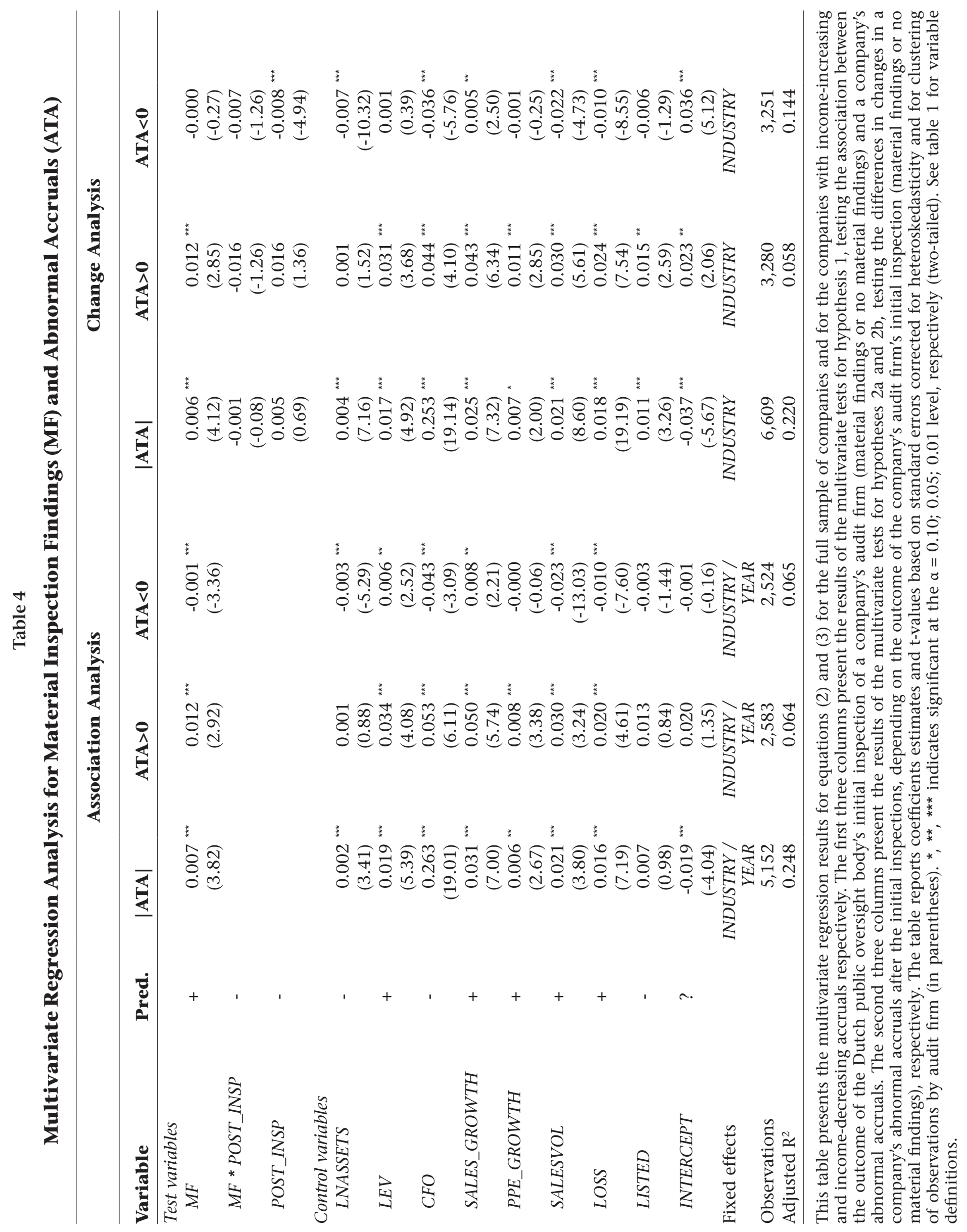


abnormal accruals $(|A T A|$ and $A T A>0)$, and the Dutch public oversight body's inspection outcome $(M F)$ for the company's audit firm ( $p=0.000$ and 0.005 respectively). For incomedecreasing abnormal accruals $(A T A<0)$, we find a significant negative association $(p=$ 0.002). The results for the control variables are mostly as expected based on prior literature. ${ }^{17}$ Overall, these results support $\mathrm{H} 1$, and suggest that independent public oversight inspections by the AFM were able to distinguish between high and low quality audit firms.

Regarding the change in earnings quality form the pre- to the post-inspection period, we find no support for $\mathrm{H} 2 \mathrm{a}$ and $\mathrm{H} 2 \mathrm{~b}$. For the full period 2005-2008, we report a significant positive association between absolute and income-increasing abnormal accruals $(|A T A|$ and $A T A>0)$, and material inspection findings $(M F)$ for the company's audit firm ( $p=0.000$ and 0.006 respectively). For absolute and income-increasing, ( $|A T A|$ and $A T A>0$ ) neither the interaction between $M F$ and POST_INSP, nor the indicator variable POST_INSP are significant. For income-decreasing abnormal accruals $(A T A<0)$ the indicator variable POST_INSP is significant and negative. These results indicate that there appears to have been hardly any change, and in particular no improvement, in earnings quality from pre- to post-inspections. This finding is confirmed using a difference-in-differences design estimated with our control variables (not reported for brevity) as the results show no significant difference-in-differences.

\subsubsection{Sensitivity Analyses}

\section{Categories of Audit Firms}

We perform additional tests to check whether our findings also hold for different categories of audit firms. First, we re-estimate equations (2) and (3), but now run separate regressions for two subgroups: (1) companies audited by a PIE audit firm (i.e. an audit firm that applied for a license to perform statutory audits for PIEs, i.e., listed companies, banks and insurance companies)), and (2) companies audited by a non-PIE audit firm. In Dutch audit regulation an important distinction is made between audit firms that audit PIEs and those that have only non-PIE clients in their portfolio. Although both types of audit firms need to comply with Dutch audit regulation in order to be allowed to perform statutory audits in the Netherlands and are subject to public oversight, audit firms that intend to perform statutory audits for PIE clients have to comply with additional standards and arguably have higher reputation risk. Untabulated regression results show that our findings in Table 4 are robust for client companies of both PIE and non-PIE audit firms. The test variable $M F$ is significant at 1 percent for absolute and income-increasing abnormal accruals $(|A T A|$ and $A T A>0)$ for PIE audit firm clients $(p=0.002$ and 0.006

17 As noted in the research design, we do not include a Big 4 audit dummy in our main model since in this study Dutch Big 4 audit firms cannot be considered a homogenous group with regard to audit quality. However, including a Big 4 dummy in the regression model gives robust results for our variable of interest, MF. We refer to the sensitivity tests for a further analysis of our findings for different categories of audit firms. 
respectively) and at 10 percent for non-PIE audit firm clients ( $p=0.058$ and 0.090 respectively) in the association analysis. If we further subdivide the non-PIE audit firms into groups based on the number of audit clients, and run separate regressions, we find that our test variable $M F$ is significant for the larger audit firms and not for the 15 smallest firms with 35 audit clients or less. We find no support for H2a and H2b for either PIE or non-PIE audit firm clients.

\section{Earnings Management Incentives}

As pointed out by Ball (2013) and Eshleman and Guo (2014a), examining the magnitude of a company's abnormal accruals may not be sufficient evidence to infer the extent of a company's earnings management without taking management incentives or the predicted direction of earnings management into account. To address this issue, we run an analysis to distinguish companies with an incentive to manipulate earnings from those without such an incentive based on their leverage. Following the debt-equity theory, highly leveraged companies have incentives to manage earnings upwards to prevent violations of debt covenants (e.g., DeFond and Jiambalvo 1994; Watts and Zimmerman 1990; Young 1999). Therefore, in order to distinguish companies with an incentive to manipulate earnings from those without such an incentive, we re-estimate equations (2) and (3) for above- and below-median leveraged companies separately. The distinction between high and low quality audit firms is expected to be more pronounced in the earnings quality of companies with an incentive to manipulate earnings. Untabulated regression results show that our findings in Table 4 are robust for abovemedian leveraged companies: $M F$ is significant and positive for both absolute and income-increasing abnormal accruals ( $p=0.000$ and 0.002 respectively). For belowmedian leveraged companies, $M F$ is insignificant. We find no support for $\mathrm{H} 2 \mathrm{a}$ and $\mathrm{H} 2 \mathrm{~b}$ for either above- or below-median leveraged companies.

\section{Alternative Accruals Measure}

DeFond and Jiambalvo (1994) and Teoh et al. (1998) argue that non-working capital accruals are less susceptible to manipulation than working capital accruals. Therefore, as a sensitivity test, we use DeFond and Park's (2001) abnormal working capital accruals (AWCA) model as an alternative measure of accruals quality which is also used in a number of audit quality studies (e.g., Carey and Simnett 2006; Francis and Wang 2008; Van de Poel and Vanstraelen 2011). The regression results for equations 2 and 3 using $A W C A$ show a significant positive association between our variable of interest, $M F$, and absolute $A W C A(p=0.000)$, income-increasing $A W C A(p=0.075)$, and income-decreasing $A W C A(p=0.000)$. We find no association between the inspection outcomes and a change in earnings quality when using $A W C A$ as dependent variable. 


\subsubsection{Additional Analysis of Material Findings}

In addition to inspections at the client engagement level, the AFM inspections also consist of an in-depth assessment of the audit firm's internal quality control procedures and audit files to test whether these are fully compliant with the quality control requirements as set out in the AFS Act, or whether there are any material deficiencies. Exhibit 1 contains a summary of these requirements. We have been able to review the AFM files in order to identify the deficiencies that were communicated with the audit firms. For all 34 audit firms with material findings we have analyzed the types of deficiencies identified by the AFM.

The material findings identified by the AFM are related to six types of deficiencies. The first type (QC_SYSTEM) involves the design of the quality control system and includes all deficiencies regarding the audit firm's general and integrity policies and procedures, and its duty of care. The second type (PERF_DOC) involves the performance and documentation of audits and includes audit file deficiencies such as the lack of sufficient appropriate audit evidence, the lack of an adequate audit trail, and a malfunctioning of the audit engagement acceptance and continuance procedures. The third type (EXCEPT) involves exceptional issues in audits, such as issues relating to consultation procedures and fraud. The fourth type (INDEP) involves the audit firm's or auditor's independence and includes findings with regard to specific independence issues, a lack of professional skepticism, or inappropriate client account records (i.e., no appropriate distinction between audit fees and non-audit fees). The fifth type (REVIEW) involves the engagement quality control reviews and the monitoring and internal inspection reviews. Thesixth type(ORG_STRUCT) involves the auditfirm's organizational structure, including deficiencies in its voting-rights structure and availability of (human) resources.

Table 5

\section{Frequency of Types of Deficiencies}

Types of Deficiencies

Audit firms with

material findings $(\mathrm{n}=32)$

Design of the quality control system (QC_SYSTEM) $69 \%$

Performance and documentation of audits (PERF_DOC) $84 \%$

Exceptional issues in audits (EXCEPT) $38 \%$ Independence (INDEP) $84 \%$ Reviews (REVIEW) $91 \%$ Organizational structure (ORG_STRUCT)

This table presents for each type of material findings the proportion of audit firms with material inspection findings for which the Dutch public oversight body identified that type of material findings during the license inspection process. See table 1 for variable definitions. 
For each of the six types of deficiencies, the audit firms were coded 1 if the AFM had material findings with regard to that particular type of deficiency, and otherwise 0 . The material deficiencies identified by the AFM involve both deficiencies in the description of the formal procedures as well as in the actual functioning of these procedures. ${ }^{18}$ Table 5 provides the total frequency of types of deficiencies for the audit firms with material findings. ${ }^{19}$

In order to find which types of deficiencies identified by the AFM are most able to discriminate audit quality, we replace the $M F$ variable with each of the six types of deficiencies variables in six separate multivariate regressions for equation (2) for those companies audited by an audit firm with material findings. ${ }^{20}$ Table 6 presents the regression results for absolute abnormal accruals. This table shows that for companies audited by audit firms with material findings, absolute abnormal accruals are incrementally larger when the audit firm deficiency involves the performance and documentation of audits (PERF_DOC), exceptional issues in audits (EXCEPT), auditor independence (INDEP), and their internal (quality control) reviews (REVIEW). Untabulated results show that in the analyses of income-increasing accruals, QC_SYSTEM (i.e., the design of the quality control system of the audit firm), PERF_DOC, INDEP, and REVIEW are also significant and positive. In the analyses of income-decreasing accruals, only REVIEW is significant and negative.

Finally, we perform a regression test including a variable WSUM, measuring the sum of the different types of deficiencies, ranging from 0 to 6 for the full sample. Untabulated results show that the number of different types of deficiencies identified for the company's audit firm, is significantly and positively associated with absolute and income-increasing abnormal accruals ( $p=0.000$ and 0.002 respectively), and significantly and negatively with income-decreasing abnormal accruals $(p=0.001)$. These results indicate that, consistent with the results presented in Table 4 , a higher number of different types of deficiencies identified by the public oversight body is associated with lower earnings quality. Collectively, we find that both the fact that there are material findings and the amount of different types of deficiencies at audit firm level are associated with earnings quality at the client firm level.

18 For instance, a deficiency with regard to the independence requirements can involve a material omission in the audit firm's independence safeguards as described in its quality manual, as well as an actual breach in its independence from a particular audit client.

19 We note that Table 5 does not represent the number of deficiencies identified by the public oversight body, but rather the percentage of audit firms for which the public oversight body identified material findings regarding the respective types of deficiencies.

20 Since the six types of deficiencies are highly correlated, including all six types of deficiencies in one regression would lead to bias due to multicollinearity with VIF-values for five out of six types variables ranging from 7.72 to 30.44 . 


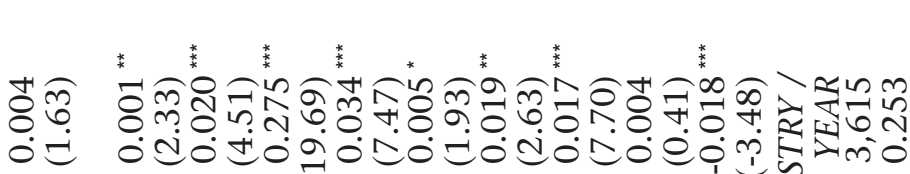

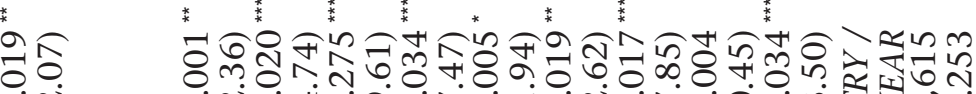
od

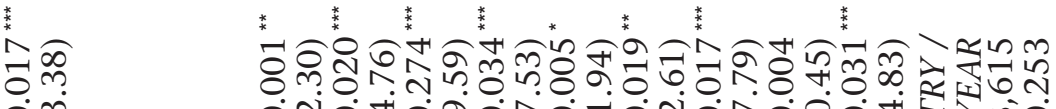

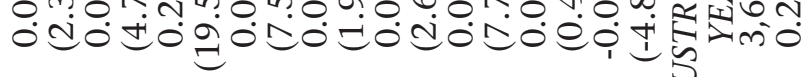

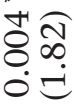

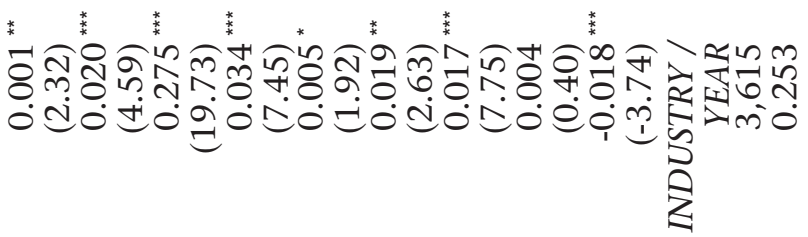

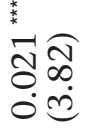

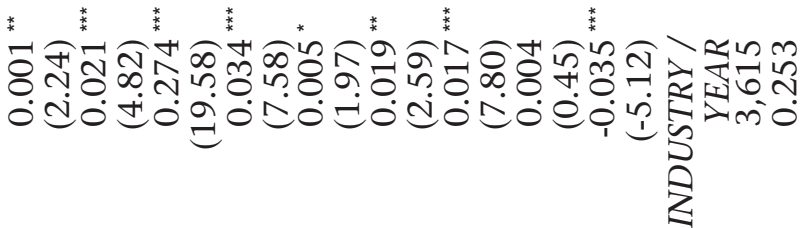

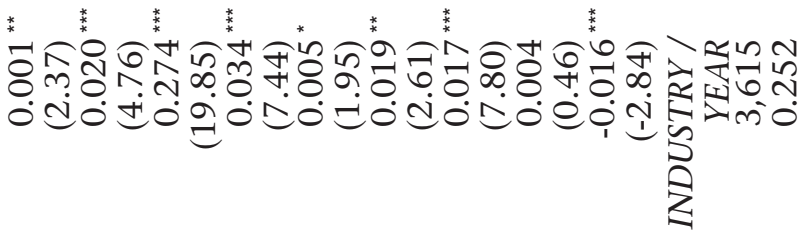

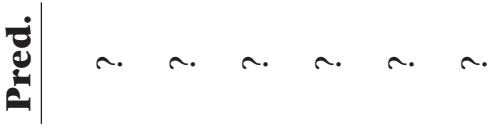
齐

$\stackrel{\text { : }}{:}$ 


\subsubsection{Additional Analysis of Peer Reviews}

By means of comparison, we also look into the effectiveness of the former peer reviews in distinguishing and improving audit quality. Prior to the installment of the Dutch public oversight body, audit firms were subject to a mandatory peer review system. In a peer review an audit firm's internal quality control system and the quality of the professional work was reviewed by auditors ('peers') that were not employed by or otherwise affiliated with the reviewed audit firm. In the Netherlands, the peer reviews were performed under the responsibility of the inspection units of the professional bodies for registered auditors. These inspection units appointed the reviewers. However, the peer review regulation included the option for audit firms to request the inspection unit to appoint another audit firm to perform the peer review, instead of the reviewers otherwise appointed by the inspection unit. In practice, particularly the larger or PIE audit firms made use of this option and were therefore often reviewed by another (large) audit firm, rather than by reviewers from different audit firms.

The peer reviews culminated into an overall assessment of the audit firm, which can also be classified as 'no material findings' and 'material findings'. While peer reviewers are actively participating in the audit market and are therefore expected to have sufficient expertise to detect deficiencies in audit quality, their independence may be impaired by their employment by an audit firm that is also subject to the same peer review process. For that reason, peer reviewers may be less effective in distinguishing between high and low quality audit firms.

We construct a second sample equivalent to the sample used in our main analysis described before. We only include companies for which the audit firm had been subject to both the public oversight inspection and the peer review process. Since the peer reviews considered in this study were conducted in the years 2005 and 2006, and involved reviews of most recently finalized audit files, we investigate the earnings quality of companies in the audit firm's client portfolio in the years 2003-2004 to test for an association between the peer review outcomes and earnings quality. In order to test whether earnings quality increased in the period after the peer reviews, we compare earnings quality in the years 2003-2004 with earnings quality in the years 2005-2006. This results in a sample of 4,610 company-year observations over the years 2003-2004, and a sample of 9,585 company-year observations over the years 2003-2006 to test the change in earnings quality. These observations involve 3,224 unique companies audited by 30 unique audit firms. These 30 audit firms include mainly the larger audit firms out of our initial sample of 51 audit firms, and still account for approximately 80 percent of all statutory audits in the Netherlands. ${ }^{21}$

21 Since the number of audit firms that received both a peer review outcome and an inspection outcome $(n=30)$ is lower than the number of audit firms included in our main analysis $(n=51)$, we re-perform our main analysis on the smaller sample. Untabulated results show that the results presented in Table 4 remain robust for this smaller sample. 
We define a second independent test variable, $M F \_P R$, which is given a value of 1 if material findings were identified at the company's audit firm by the peer review system, and otherwise 0 . In this sample, the peer reviews lead to material findings for 13 of these 30 audit firms (43 percent), while the public oversight body had material findings for 18 of these 30 audit firms (63 percent). Table 7 relates the public oversight inspection outcomes to the peer review outcomes. It shows that for 16 audit firms (53 percent) the public oversight inspection came to the same outcome as the prior peer review and for 14 audit firms (47 percent) the public oversight inspections came to a different conclusion than the peer reviewers. When performing a Pearson Chi 2 test, we find no significant relationship between the public oversight inspection outcomes and the peer review outcomes ( $p=0.558$ ). The correlation coefficient between $M F$ and $M F \_P R$ is 0.107 and insignificant. This finding is consistent with the AFM's report after its first inspections, stating that it could not rely on prior peer review outcomes ${ }^{22}$ and needed to perform more inspections.

Table 7

\section{Inspection Outcomes and Peer Review Outcomes for 30 Audit Firms}

\begin{tabular}{lccc}
\hline & $\begin{array}{c}\text { Peer review outcome: } \\
\text { material findings }\end{array}$ & $\begin{array}{c}\text { Peer review outcome: } \\
\text { no material findings }\end{array}$ & Total \\
\hline $\begin{array}{l}\text { Inspection outcome: } \\
\text { material findings }\end{array}$ & 7 & 10 & 17 \\
$\begin{array}{l}\text { Inspection outcome: no } \\
\text { material findings } \\
\text { Total }\end{array}$ & 4 & 9 & 13 \\
\hline
\end{tabular}

This table presents the outcomes received from the public oversight body and the peer reviews for the 30 audit firms that received both types of outcomes.

To test whether peer review outcomes were associated with earnings quality and whether peer review lead to higher earnings quality in the following period, we replace $M F$ by $M F \_P R$ in equations (2) and (3). The results, reported in Table 8, show that the coefficient on $M F \_P R$, measuring the peer review outcome, is significantly negative for absolute abnormal accruals and insignificant for income-increasing, or incomedecreasing abnormal accruals. Further, the outcomes of the peer review appear to have had no effect on earnings quality in the period following those reviews: the coefficient for the interaction term $M F \_P R^{*} P O S T_{-} R E V$ is insignificant, while the coefficient for $P O S T \_R E V$ is positive and significant, indicating an overall increase in absolute and

\footnotetext{
${ }_{22}$ The report is available (in Dutch) on: http://www.afm.nl/nl-nl/professionals/nieuws/2007/sep/ evaluatie-niet-oob-vergunningaanvragers.
} 


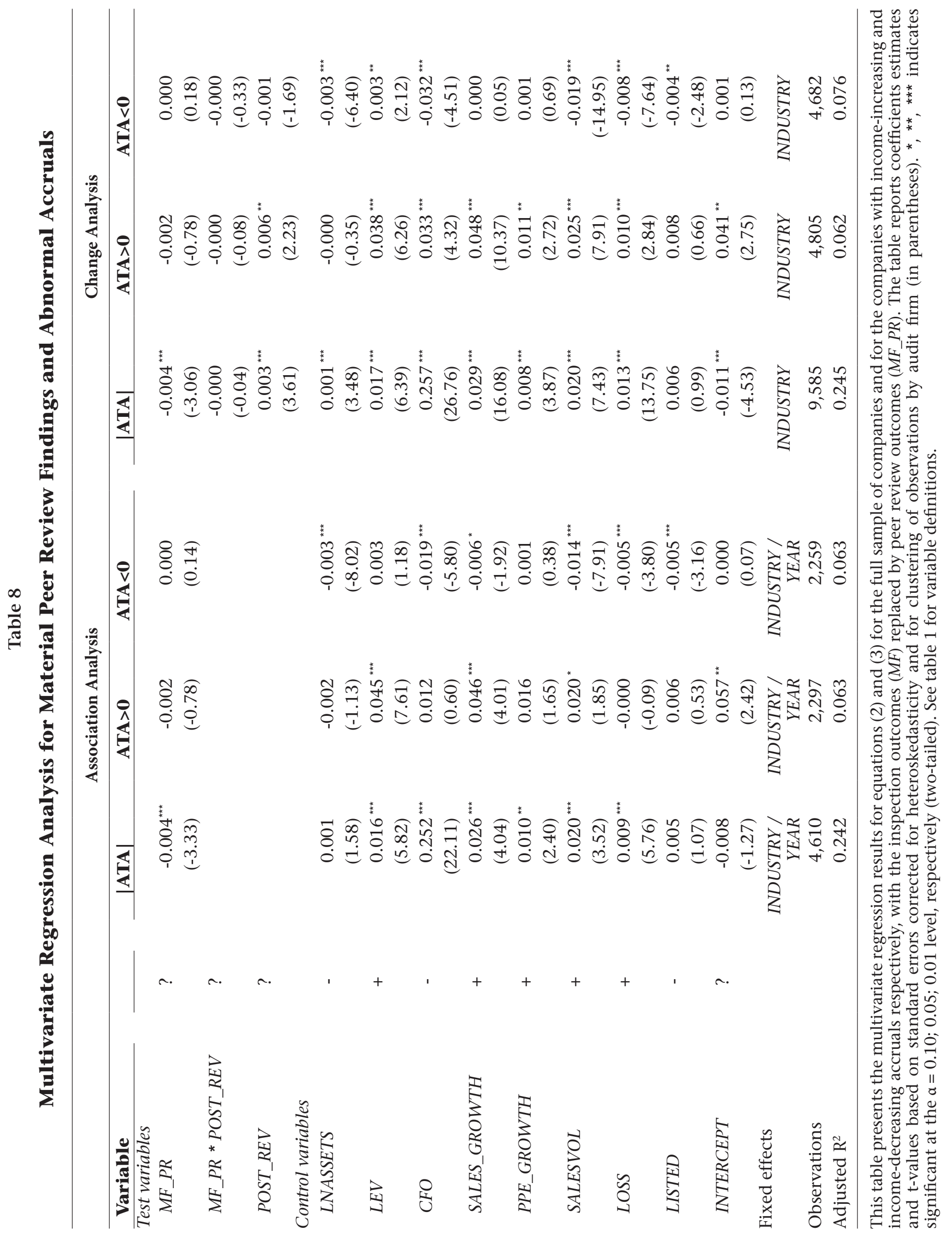


income-increasing abnormal accruals in the period after the peer reviews. When running the regressions separately for companies audited by PIE and non-PIE audit firms (not tabulated), we find similar results. There is no significant association between the audit firm's peer review outcome and (a change in) earnings quality for either PIE audit firm clients or for non-PIE audit firm clients.

Overall, these findings indicate that while there is a significant association between the Dutch public oversight outcomes and earnings quality of the clients of the inspected audit firms, there is no support for such an association with the peer review outcomes.

\subsection{Conclusion}

Given the amount of resources spent on independent public oversight, the effectiveness of public oversight is an important empirical question. We address this question using proprietary data of the Dutch public oversight body containing overall outcomes of its first-time inspections conducted for audit firm license approval. Our paper is one of the first to provide evidence on the quality of independent inspection outcomes in an E.U. setting, the Netherlands, which was one of the first European countries that removed the responsibility for audit quality assurance from the auditing profession.

Overall, our results provide evidence that the Dutch independent inspection outcomes credibly reflect audit quality. However, in contrast to U.S. evidence, we do not find evidence to support an improvement in audit quality after the first inspection round. Hence, these results provide only partial support for the effectiveness of the Dutch public oversight system. While being able to distinguish audit quality is a basic premise for the appropriate functioning of a public oversight body, the ability to improve audit quality is arguably even more important for which we fail to find support. One possible explanation could be that audit firms may have less incentives to improve after receiving a deficient inspection report in a setting where those firm-specific inspection reports are not publicly disclosed.

Our results further show that the types of deficiencies identified by the public oversight body that are most able to differentiate audit quality are related to the performance and documentation of audit engagements, auditor independence, and (internal quality control) reviews. This finding is constructive to recent U.S. research since the public portion of a PCAOB report typically does not divulge quality control problems when addressed within a period of 12 months. In addition, it supports the current emphasis of standard setters and regulators such the EC, IAASB and PCAOB to focus on promoting auditor independence and audit firm governance and quality control systems to improve audit quality.

By means of comparison, we examine in an additional analysis a subsample of audit firms for which we have both the inspection outcome of the Dutch public oversight body and the prior peer review outcome. Using this subsample, we continue to find a 
significant association between the inspection outcomes and earnings quality, but fail to find a similar association between a company's earnings quality and the outcome of the prior peer reviews. This would suggest that audit firms in the Netherlands were subject to 'friendly' peer reviews, which may not to be surprising since audit firms, and in particular the larger and PIE audit firms, made use of the option to choose their peer reviewer. Furthermore, similar to public oversight, we do not find support for an improvement in audit quality after a peer review outcome.

Our study is subject to a number of limitations. First, we rely on abnormal accruals to measure audit quality. Financial restatements, another commonly used measure of audit quality, are not available in the Netherlands, and the limited number of bankrupt companies in our sample period makes use of going concern opinions (GCO) infeasible. ${ }^{23}$ Second, we measure audit quality at client level, while the public oversight body provides an opinion at the audit firm level. While client-level measures are often used to provide information on audit firm quality (e.g., Francis and Michas 2013), there is a mismatch between these levels of analysis. While analysis at the audit firm level would beinteresting, it would require developing a methodologically sound composite audit quality measure at that level, a challenging task in itself. ${ }^{24}$ Finally, a sound analysis at audit firm level would require a sufficient number of observations to have adequate power, and our sample is limited to 51 audit firms. In our setting, the concern about mismatch of levels of analysis is partially offset as the AFM includes inspections at the audit engagement level, focusing on both GAAP and GAAS deficiencies, in their evaluation of audit firms. ${ }^{25}$ A third limitation is that our findings relate to the first inspection outcomes for the granting of audit firm licenses, and thus the effect of subsequent inspection outcomes is unknown. Our study also does not allow to draw conclusions on which system, peer review or independent public oversight, is more effective, partly due to the time gap between the public oversight and peer review outcome data. Finally, we cannot rule out the possibility that client companies with low quality financial statements selected a low quality audit firm. However, a public oversight body is expected to identify audit firms allowing client companies to report low-quality earnings.

While we can only speculate that audit firm behavior may be affected by whether or not inspection reports are publicly disclosed, this conjecture could specifically be addressed in future research in for example a setting where there is a change in disclosure policy. In sum, this paper contributes to the literature by investigating inspection

23 Interestingly, Aobdia (2015), using PCAOB data, shows that abnormal accruals at client level are predictive for engagement specific deficiencies, while GCOs are not.

24 For example, does it require weighting of clients in the portfolio and if so, at what dimensions (client importance, client risk, and/or client complexity)? Further, it is not clear how to aggregate client outcomes to the firm level while also considering variation in client characteristics.

25 Our method relates a material deficiency at the audit firm level to all clients in the firm's portfolio (including the non-inspected client companies), which should bias against finding results as client companies chosen by inspectors are not random. However, we do find a significant association between a material deficiency at audit firm level and the magnitude of accruals at client level, suggesting that the opinion of the public oversight body is informative for the audit quality of the client portfolio. 
findings of the audit oversight body in the Netherlands, taking advantage of proprietary data on their inspection results as well as those of prior peer reviews. The literature on public oversight continues to grow, but many issues remain unsettled. Further international comparisons would be very useful in deepening our understanding of the impact of public oversight on auditor behavior, as would employing different research methodologies (e.g., experiment, field study). Further research comparing findings of peer review reports with public oversight inspection reports would be particularly useful in comparing the effectiveness of these mechanisms in improving audit quality. 


\section{Chapter 3}

\section{Business Relationships and Auditor Independence:}

\section{When Audit Firms are Their Clients' Clients'}

1 I am thankful for the helpful comments and suggestions received from Jean C. Bedard, Jeff Downing, Caren Schelleman, Ann Vanstraelen, Dennis Voeller, participants at the International Symposium on Audit Research 2014 in Maastricht, and participants at the European Audit Research Network Symposium 2015 in Lausanne. 


\begin{abstract}
While there is a substantial body of literature examining the impact of the provision of non-audit services and auditor tenure on auditor independence, there is surprisingly little empirical evidence on other independence threats covered by independence regulation. The purpose of this study is to assess how audit firms respond to the existence of a business relationship with an audit client, in terms of adjusting their audit efforts or risk premiums, by examining the association of the business relationship with audit fees and earnings quality. A propensity-score matching approach was used in constructing a researchsamplewith proprietarydatafrom theDutchauditoversightbody, complemented with public financial statement data. The results show that business relationships are consistently associated with higher audit fees and do not negatively affect earnings quality. Interestingly, in those situations where the business relationship coincides with high non-audit fees relative to audit fees, earnings quality appears to be even higher. Overall, this study contributes to the literature on auditor independence, and may be of interest to auditors, standard setters and regulators.
\end{abstract}




\subsection{Introduction}

Independent auditing is an essential feature of efficient capital markets and regulators have long been concerned with potential threats to auditor independence (e.g., Church et al. 2015). Auditors and audit firms have a legal monopoly on performing statutory audits of financial statements and a responsibility to act in the public interest. At the same time, they operate in circumstances that may create conflicts between this public interest and their own personal and commercial interests, thereby threatening the auditor's independence. The Code of Ethics for Professional Accountants, as developed by the International Ethics Standards Board for Accountants (IESBA), establishes ethical standards for auditors, including independence requirements. ${ }^{2}$ These independence requirements deal with specific circumstances and relationships that create or may create threats to independence (e.g., provision of non-assurance services to an audit client, long association of senior personnel with an audit client, employment with an audit client, fees, business relationships, financial interests, family and personal relationships, gifts and hospitality, and actual or threatened litigation).

Prior studies on auditor independence have dealt with a number of the circumstances and relationships influencing independence, often to examine their association with audit quality (see for reviews for example Beattie and Fearnley 2002; Bedard et al. 2008; Gramling et al. 2010; Tepalagul and Lin 2015; Church et al. 2015). Mainly because of lack of data, not all of the circumstances and relationships covered by the Code of Ethics have been addressed by prior studies. The purpose of this study is to examine one of these unaddressed relationships, i.e., business relationships between audit firms and their audit clients. Business relationships arise from commercial relationships or common financial interests between the audit firm and the audit client. This study focuses on business relationships in which the audit firms purchases goods and services from an audit client. Such business relationships arise when an audit firm procures for instance its audit software from an IT company, its office buildings from a construction company, or its business loans from a bank, while the audit firm is also performing statutory audits for those companies.

The Code of Ethics recognizes that business relationships may create self-interest or intimidation threats (IESBA 2013, paragraph 290.124), and thereby negatively impact audit quality. Public oversight bodies, including the Dutch audit oversight body, have called for clearer, unambiguous and more restrictive rules for auditor independence, including those regarding business relationships (AFM 2011). This paper contributes to the literature on auditor independence, by providing first-time insights in business relationships between audit firms and audit clients, of which necessary data are not

2 In pursuing its mission to serve the public interest, the International Federation of Accountants (IFAC) Board has established the IESBA which developed and issued, under its own authority, the Code of Ethics for Professional Accountants, for use around the world (IESBA 2013, 7). 
commonly available, and their association with audit fees and earnings quality. Its results will also inform practicing auditors, standard setters and regulators.

In this paper, I aim to assess how audit firms adjust their efforts and/or risk premiums when they maintain a business relationship with an audit client. Specifically, I examine the association between the existence of an auditor-client business relationship and both audit fees and earnings quality. The audit firm may consider the business relationship a threat to the auditor's independence and may attempt to mitigate this threat with safeguards, as required by the independence regulation, such as additional audit or review efforts, or other quality control measures. If so, engagement effort would increase. Alternatively, but more likely simultaneously, the audit firm may consider the business relationship a risk and attempt to cover it by charging a price premium to the audit client. In both cases, audit firms are expected to charge higher fees to audit clients with which they maintain a business relationship. Increased audit effort and/or quality control measures may also actually improve the quality of the audit, which could be reflected in higher earnings quality. However, if a business relationship impairs the auditor's independence, the auditor may perform a below-standard audit, with lower audit fees and lower earnings quality.

I use a propensity-score matching approach to construct a sample of Dutch companies maintaining a business relationship with their audit firm ${ }^{3}$, matched with similar companies without such business relationships. Data on business relationships and audit fees are obtained from the proprietary files of the Dutch audit oversight body. ${ }^{4}$ The results show that business relationships are consistently associated with higher audit fees and, particularly in those situations where the business relationship coincides with high non-audit fees relative to audit fees, with higher earnings quality. Overall, the results suggest that audit firms respond to the circumstances in which they maintain a business relationship with an audit client, most likely by adjusting their audit efforts. However, alternative explanations for higher audit fees, such as the audit firm charging a risk premium to the audit client, cannot be completely ruled out. Importantly, I find no

3 The sample only includes business relationships with the 15 audit firms holding a license to perform statutory audits for PIEs in the Netherlands. In the Netherlands, PIEs are legal entities whose transferrable securities (both stocks and bonds) are admitted to trading on a regulated market, banks, and insurance companies. Additional quality requirements are applicable to audit firms that perform such PIE audits, including stricter independence requirements and the need to obtain a specific PIE license to perform statutory audits for PIEs.

4 In 2011, the Netherlands Authority for the Financial Markets (AFM), responsible for audit oversight in the Netherlands, performed an exploratory review regarding the independence of Dutch audit firms and auditors. The public report that was published after this review showed, amongst other things, that audit firms maintained business relationships with various audit clients (AFM 2011). The identified business relationships can be characterized as business relationships in which the audit firm purchases goods or services from an audit client, e.g., facility and personnel services, office buildings, ICT, software development, banking and insurance services, and car leasing. The AFM report 'Incentives for Audit Quality - An exploratory review' of 6 October 2011 elaborates on some specific cases of business relationships (AFM 2011, 28-31). The AFM confirmed with the audit firms the accuracy and completeness of the factual information gathered in the course of its review concerning business relationships. 
evidence of impaired independence, which would be manifested in lower audit fees and lower earnings quality. These results appear robust for a number of sensitivity tests on cross-sectional subsamples (e.g., based on the audit firm size (Big 4 or non-Big 4), type of audit client (PIE or non-PIE), demand for audit quality, and client risk), as well as for an alternative measure of business relationships (i.e., the monetary value of these business relationships) and alternative matching methods.

The remainder of this paper proceeds as follows. The next section reviews prior literature on auditor independence and independence regulation, and provides some background information on the accounting and auditing environment in the Netherlands. The third section presents the research hypotheses, and the fourth section describes the research sample and the empirical models used in the analyses. The empirical findings are reported in the fifth section, followed by a number of sensitivity tests in the sixth section. Finally, the last section provides the conclusion, limitations, and suggestions for further research.

\subsection{Background}

\subsubsection{Prior Literature}

A number of papers provide reviews of the already extensive literature on auditor independence (e.g., Beattie and Fearnley 2002; Bedard et al. 2008; Gramling et al. 2010; Tepalagul and Lin 2015; Church et al. 2015). Since auditor independence coincides with auditor objectivity and the ability to withstand client pressure to acquiesce to substandard reporting (DeFond et al. 2002), independence rules are intended to minimize the possibility that external factors will inappropriately influence an auditor's judgment, thus promoting high-quality audits (Gramling et al. 2010). Higher audit quality can be defined as greater assurance that the financial statements faithfully represent relevant information about the company's underlying economics, conditioned on the company's innate characteristics and financial reporting practices (DeFond and Zhang 2014). The supply of high-quality audits is believed to be a function of the auditor's competence and independence, where competence refers to the auditor's ability to discover deficiencies in the client's financial reporting, and the auditor's independence refers to the auditor's willingness to report these discovered deficiencies, arising from reputation and litigation incentives (e.g., DeAngelo 1981a; Dechow et al. 2010; Watts and Zimmerman 1983). Therefore, if the auditor's independence is threatened, audit quality may become impaired.

According to the CodeofEthics(IESBA2013, paragraph290), certain circumstances and relationships may create threats to independence to which the conceptual framework approach should be applied (e.g., provision of non-assurance services to an audit client, long association of senior personnel with an audit client, employment with an audit client, fees, business relationships, financial interests, family and personal relationships, 
gifts and hospitality, and actual or threatened litigation). Prior research has extensively covered the first four types of circumstances and relationships: non-audit services, auditor tenure, employment with an audit client, and fee dependence.

Regulators are generally concerned that non-audit services make auditors financially dependent on their clients and that the consulting nature of many non-audit services puts auditors in managerial roles (DeFond et al. 2002), while audit firms argue that the provision of non-audit services improves the performance of the audit (Knechel and Sharma 2012) or creates efficiencies from knowledge spillover effects (Simunic 1984). Overall, prior research indicates that the provision of non-audit services has rarely been associated with impaired audit quality, and in some cases it is associated with higher audit quality (Church et al. 2015; DeFond and Zhang 2014; Gramling et al. 2010). However, while Bell et al. (2015) find on average no association between non-audit services and audit quality, they do find a positive association for listed companies and a negative association for privately held companies. Furthermore, many studies have shown that higher fees for non-audit services are associated with higher audit fees (e.g., Simunic 1984; Palmrose 1986b; Hay et al. 2006). For a more elaborate overview of the literature on non-audit services and auditor independence, I refer to Sharma (2014).

The length of the association between the auditor and the audit client (i.e., auditor tenure) has also been widely studied. While behavioral studies find that long associations impair audit quality and support the importance of independence achieved by rotation, archival studies on auditor tenure, and the related topics of audit firm and partner rotation, provide mixed results (Bedard et al. 2008). For instance, Chi et al. (2009) find little evidence that mandatory partner rotation is associated with higher audit quality, proxied by abnormal accruals and earnings response coefficients. Using the frequency of audit adjustments as an alternative measure for audit quality, Lennox et al. (2014) do find audit quality to be higher in the years surrounding a mandatory auditor rotation. Bell et al. (2015) find that audit quality is lower in the first year of the engagement, improves shortly thereafter and declines for very long engagements. However, they find the decline in audit quality only applies to privately held companies. For listed companies, audit quality remains high with very long tenure. Audit fees are generally lower in audits where the auditor is relatively new to the engagement, i.e. with shorter tenure, either because of 'low-balling' (DeAngelo 1981a), or because the new auditor can offer more efficient service (e.g., Francis and Simon 1987; Simon and Francis 1988; Deis and Giroux 1996; Gregory and Collier 1996; Craswell and Francis 1999; Hay et al. 2006).

When auditors leave the audit firm and are employed by an audit client, particularly private investors demonstrate concern with independence (Dart and Chandler 2012). This 'revolving-door' situation may impair either the particular auditor's independence in the audit periods leading up to the employment by the audit client, or the audit firm's independence in subsequent audits (Gramling et al. 2010), or both. A one-year coolingoff period appears to be beneficial (Wright and Booker 2010). Although several recent studies measuring the quality of accounting accruals provide little evidence that the quality of audited financial statements is actually affected in such employment situations 
(Gramling et al. 2010; Geiger et al. 2008; Geiger et al. 2005), others find that 'affiliated' companies are significantly more likely than unaffiliated companies to receive clean audit opinions (Lennox 2005) and report larger signed and unsigned abnormal accruals than other companies (Menon and Williams 2004).

Regarding the argument that audit firms' independence may be impaired by the fees received from audit clients, prior research suggests that the relative size of the audit client does not affect perceived independence (Pany and Reckers 1980), nor does it influence abnormal accruals (e.g., Reynolds and Francis 2001; Chung and Kallapur 2003), not even when fees are below costs in first-year engagements ('low balling') (Gramling et al. 2010).

On balance, prior studies have found little evidence for a negative effect of these threats on audit quality, and even some evidence that audit quality may actually improve. However, regulators still frequently express concerns about various potential threats to auditor independence (e.g., Church et al. 2015; AFM 2011). DeFond and Zhang (2014) observe that the perceived threats typically present a tradeoff between reduced auditor independence, which impairs audit quality, and improved auditor competence, which improves audit quality. Thus, finding that some threats do not impair audit quality, and even improveit in some cases, is evidence consistent with auditor competence playing an important role in explaining audit quality.

Currently, there appears to be very little or no prior research on the other circumstances and relationships covered by the Code of Ethics, including business relationships. One early study by Lavin (1976) touched upon a specific example of a business relationship, finding that CPAs, lending officers, and research financial analysts mostly perceived an audit firm with its office in a building owned by a client to be independent. The current paper contributes to the literature by examining the fairly unexplored topic of business relationships and audit firms' responses in terms of audit fees and earnings quality when they maintain these business relationships with audit clients.

\subsubsection{Dutch Accounting and Auditing Environment}

The Dutch accounting regulatory environment is well described by Schelleman and Knechel (2010). The Netherlands is generally regarded as a country with a well-developed capital market system, with broad share ownership, and accounting and auditing traditions similar to the U.S. and U.K. (Mueller et al. 1994; Nobes 1998), although the Dutch litigation environment is not as severe as in the U.S. As of 1 January 2005, listed Dutch companies are required to apply International Financial Reporting Standards (IFRS) as promulgated by the IASB and adopted by the E.U. in their consolidated financial statements. Many aspects of the Dutch audit market closely resemble those in AngloSaxon countries, including that the international audit firms are all present, and dominate the market by auditing the majority of listed companies (Bröcheler et al. 2004; Langendijk 1997; Boone et al. 2000). Since 1 October 2006, audit firms are subject to an 
independent audit oversight body, the Netherlands Authority for the Financial Markets (AFM). The AFM grants licenses to audit firms that have demonstrated that they comply with the quality control requirements that are primarily based on the 'International Standard on Quality Control 1' (IAASB 2009b). Thereafter, the AFM performs periodic risk-based inspections, thematic reviews, and investigations, and is empowered to impose sanctions, such as warnings, instructions, incremental penalty payments, and administrative fines. Audit firms are legally obliged to provide any information requested by the oversight body and fully cooperate with any inspection or investigation performed by the oversight body.

\subsection{Development of Hypothesis}

Business relationships arise from commercial relationships or common financial interests between the audit firm, or a member of the audit team, or a member of that individual's immediate family, and the audit client or its management (IESBA 2013, paragraph 290.124). Generally, a business relationship in which the audit firm purchases goods and services from an audit client, does not create a threat to independence if the transaction is in the normal course of business and at arm's length. However, the nature or magnitude of the transactions may be such that they create a self-interest threat (IESBA 2013, paragraph 290.126). When the goods or services provided by the audit client are of importance to the auditor, the audit client has the ability to put pressure on the auditor and to influence his objectivity. This may occur if the audit client provides goods or services that are instrumental to the everyday business of the audit firm (e.g., providing office space to the audit firm, car leases for all personnel, business loans to individual audit partners). These types of business relationships are therefore expected to be of economic importance to the audit firms involved. I examine whether these business relationships also affect audit firms' behavior.

The Code of Ethics prescribes the application of the conceptual framework in particular circumstances: "the firm and the members of the audit team shall evaluate the implications of circumstances and relationships and determine whether safeguards [...] can be applied when necessary to eliminate the threats to independence arising from these circumstances and relationships or reduce them to an acceptable level" (IESBA 2013, paragraph 290.100, p.54). Therefore, the auditor is required to conduct a self-assessment of his independence by identifying and evaluating threats arising from a business relationship and taking measures to safeguard his independence where necessary.

If the auditor's independence is threatened, for instance by a self-interest threat caused by a material business relationship or high non-audit fees (or a combination thereof), audit quality may become impaired. After all, auditor independence coincides with auditor objectivity and the ability to withstand client pressure to acquiesce to substandard reporting (DeFond et al. 2002). In order to perform a higher quality audit, i.e., to provide greater assurance that the financial statements faithfully represent 
relevant information about the company's underlying economics conditioned on the company's innate characteristics and financial reporting practices (DeFond and Zhang 2014), the auditor will have to be both competent and independent (e.g., DeAngelo 1981a; Dechow et al. 2010; Watts and Zimmerman 1983).

If an auditor's independence is threatened, and thereby the level of audit quality potentially impaired, this may be considered an audit risk. Audit risk is defined in the International Standards on Auditing (ISAs), as developed by the International Auditing and Assurance Standards Board (IAASB), as the risk that the auditor expresses an inappropriate audit opinion when the financial statements are materially misstated. Audit risk is a function of the risks of material misstatement (consisting of inherent risk and control risk) and detection risk. In particular, a loss of objectivity is expected to increase the risk that the auditor does not detect a material misstatement, which he might have detected otherwise. Furthermore, threatened auditor independence may increase the risk of litigation. First, the audit oversight body may impose sanctions in case of a breach of independence regulation, causing both financial and reputational costs for the auditor and audit firm. Second, in case of an audit failure, third parties may litigate and use the threatened independence as an argument to strengthen their case against the auditor or audit firm (Schmidt 2012).

Francis and Krishnan (1999) describe various ways in which a rational auditor might respond to uncertainties or risks: (1) the auditor could expend more effort, (2) the auditor could screen out high-risk clients, (3) the auditor could charge a premium to compensate for risk, (4) the auditor could negotiate with the audit client to make adjustments or other measures to mitigate the uncertainties or risks, or (5) the auditor could express the uncertainties or risks in a modified audit report. This paper focuses on the first and third potential strategies, both of which will culminate in higher audit fees charged by the audit firm to the audit client, as also proposed by Seetharaman et al. (2002).

Independence rules require auditors and audit firms to take quality control measures or other safeguards in case the auditor's independence is threatened, such as additional audit or review efforts, in order to promote high-quality audits (Gramling et al. 2010). Prior studies find the amount of hours spent on the audit, i.e., audit effort, to be positively related to audit quality (e.g., Caramanis and Lennox 2008; Deis and Giroux 1996; Deis and Giroux 1992; Palmrose 1989, 1986a). Higher audit fees, ceteris paribus, are generally considered indicative of greater effort on the engagement, rather than of economic bonding between the auditor and the client (Eshleman and Guo 2014a). The audit firm may also attempt to compensate for increased risk and to cover possible future (litigation) losses by charging an insurance premium to the audit client (e.g., Ghosh and Pawlewicz 2009; Seetharaman et al. 2002; Simunic 1980). Prior studies provide evidence that an increase in audit fees is at least partly or almost exclusively due to higher levels of auditor effort, rather than to a pure price or risk premium (e.g., Lobo and Zhao 2013; Schelleman and Knechel 2010; Simunic and Stein 1996). Hence, it is expected that charging a price premium to compensate for increased litigation risk is happening 
simultaneously with, rather than as an alternative to increased audit effort. ${ }^{5}$

Increased audit effort intended to safeguard the auditor's independence is expected to result in higher earnings quality, especially when the increased effort (also) consists of obtaining additional audit evidence and performing more audit work. If increased effort merely consists of more extensive reviews or other quality control measures, it may not necessarily lead to higher earnings quality, but at the least safeguard earnings quality at a steady (i.e., unchanged) level. A risk premium charged to the audit client, without differential audit effort (intended to compensate for losses the auditor may incur from a future independence threat) is also not likely to change earnings quality.

Assuming that auditors are compliant with independence regulations requiring them to take appropriate safeguards, it is expected that auditors respond to a business relationship by increasing their audit effort or quality control measures, resulting in higher audit fees and higher earnings quality. ${ }^{6}$ Hence, the following research hypotheses are posited:

H1a: Business relationships between audit firms and audit clients are associated with higher audit fees, ceteris paribus.

H2a: Business relationships between audit firms and audit clients are associated with higher earnings quality, ceteris paribus.

As previously stated, the conceptual framework prescribed in the Code of Ethics leaves it up to the auditor to conduct a self-assessment of his independence. There are no further rules or guidance prescribing which nature or magnitude of business transactions form an unacceptable independence threat, leaving ample room for judgment. This may cause auditors and audit firms facing similar situations not always carrying out the same assessment or arriving at the same conclusion (AFM 2011).

Following regulatory concerns with the application of the conceptual framework, the assumption of auditors taking appropriate measures to safeguard their independence may be flawed. If the independence threat arising from a business relationship actually

Additionally, it could be argued that the 'reciprocal' situation of a business relationship (i.e., the audit clients pays an audit fee to the auditor for the audit, and the auditor pays a fee to the audit client for the goods or services purchased) puts the audit firm in a more powerful negotiating position as compared to a mere audit-relation with a client. This increase in negotiating power could empower the audit firm to earn rents (or equivalently, make the audit client more willing to pay 'full price' for the audit and not demand any discounts). However, ex ante it is not clear to what extent this increased negotiating power would indeed lead to higher audit fees. The audit firm could also receive a discount on the purchased goods or services, leaving the audit fees unchanged.

6 This expectation follows the 'neoclassical' perspective of the audit market as proposed by Hribar et al. (2014) and supported by findings of Doogar et al. (2015). Hribar et al. $(2014,514)$ adopt a neoclassical perspective of the audit market, which assumes that auditors will increase fees to compensate for the additional risk and additional audit hours required for companies with poor quality accounting systems. Prior studies conjecture that impaired auditor independence resulting from higher fees leads to lower quality accounting information, while Hribar et al. argue that lower quality accounting systems result in higher fees charged by auditors, thereby reversing the direction of causality linking audit fees and accounting quality. 
materializes and the auditor does not respond with any mitigating measures, the auditor is expected to perform a below-standard audit, i.e., apply lower audit effort and charge lower audit fees, reflected in lower earnings quality. ${ }^{7}$ In order to test whether business relationships are associated with impaired independence, the following alternative hypotheses are formulated:

H1b: Business relationships between audit firms and audit clients are associated with lower audit fees, ceteris paribus.

H2b: Business relationships between audit firms and audit clients are associated with lower earnings quality, ceteris paribus.

In both sets of hypotheses, the hypothesized associations are expected to be stronger when the independence threat is bigger. It can be argued that an independence threat is more severe in the presence of more different types of relationships or interests. Although prior research indicates that the provision of non-audit services has rarely been associated with impaired audit quality, and in some cases it is associated with higher audit quality (Church et al. 2015; DeFond and Zhang 2014; Gramling et al. 2010), regulators and auditors are still considering non-audit services a potential threat to the auditor's independence for which safeguards must be applied. Therefore, when a business relationship coincides with (high) non-audit services, this may be considered a potentially larger threat to the auditor's independence. In the presence of two independence threats, i.e., a business relationship and high non-audit services (i.e., above-median non-audit fees relative to audit fees), the auditor's response of increasing ( $\mathrm{H} 1 \mathrm{a}$ and $\mathrm{H} 2 \mathrm{a}$ ) or decreasing ( $\mathrm{H} 1 \mathrm{~b}$ and $\mathrm{H} 2 \mathrm{~b}$ ) audit effort or quality control safeguards is expected to be stronger and associated with both higher (H1a and $\mathrm{H} 2 \mathrm{a})$ or lower $(\mathrm{H} 1 \mathrm{~b}$ and $\mathrm{H} 2 \mathrm{~b}$ ) audit fees and earnings quality.

\subsection{Research Design}

\subsubsection{Sample}

Comparing audit fees and earnings quality for companies that maintain a business relationship with their audit firm to companies that do not maintain such a business relationship can be characterized as a form of 'natural experiment'. The companies with business relationships can be considered the 'treated' observations. In order to test whether the 'treatment' has any effect, there is a need to find similar companies without business relationships to function as 'untreated' control observations.

Using fees as a proxy for audit effort is based on the assumption that the market for audit services is competitive (e.g., Craswell et al. 1995; Simunic 1980; Elliott 1998). Competition implies that fee changes are mainly caused by changes in costs rather than profit margin, which is corroborated by prior studies (e.g., Lobo and Zhao 2013; Schelleman and Knechel 2010; Simunic and Stein 1996). 
First, I collected data for the 'treated' companies with business relationships with their audit firms. I obtained information on business relationships from the AFM's proprietary files of the thematic review the AFM conducted in 2011 on incentives for audit quality, with independence as one of the key aspects under consideration. This review started with an extensive collection of data on various relationships between audit firms and their audit clients, indicating potential threats to auditors' independence. The AFM used a questionnaire to collect the data from the 15 audit firms holding a license to perform statutory audits for PIEs in the Netherlands. The AFM reviewed whether audit firms had business relationships with audit clients or third parties affiliated with audit clients in the period 1 January 2009 to 31 December 2010 related to developing, renting out, handing over or transferring property; granting or taking up loans; and supplying goods or services with a single or annual value in excess of $€ 100,000$, or sponsorship relationships with audit clients with a cost value exceeding $€ 5,000$ (AFM 2011, p.27, 33). ${ }^{8,9}$ Following this data collection, the AFM performed on-site inspections of independence procedures and selected independence cases. The AFM confirmed with the audit firms the accuracy and completeness of the factual information gathered in the course of its review. I complemented the data on business relationships with data on audit fees, also retrieved from the AFM's files, and with financial statement data needed for the empirical models described in the next section. ${ }^{10}$

Table 1 presents the descriptive statistics for the 184 business relationship observations included in the sample. ${ }^{11}$ Panel A provides a breakdown of the business relationships in various types. Facility services business relationships involve the audit firm procuring services and products from the audit client regarding office facilities, such as office supplies, printing, cleaning, catering, security, energy, and postal services. Office building business relationships involve procuring services regarding development, construction, maintenance, or rental of office buildings for the audit firm. ICT business relationships involve services regarding sales, development, or maintenance of software

8 For the purpose of this paper, the sponsorships identified separately by the AFM, are considered to be business relationships, since the reported sponsorships all involved some sort of marketing services in return (e.g., advertising, use of business seats).

9 The AFM only collected data on business relationships between audit firms and audit clients. No data were collected on comparable relationships between audit firms and companies that were not audit clients. Therefore, the available data do not allow for testing whether audit firms pay more or less for the goods or services procured from audit clients as compared to goods or services procured from non-audit clients.

10 I obtained these financial statement data from the databases Orbis and Amadeus (both distributed by Bureau van Dijk (http://www.bvdinfo.com)) and manually collected data from financial statements from Company.info. Orbis contains information on 140 million companies worldwide, with an emphasis on private company information. Amadeus is a pan-European database that contains comprehensive information on around 19 million companies across Europe. Company.info contains information on both profit and non-profit organizations on more than 2 million Dutch companies.

11 Untabulated results show that the 184 business relationships involve 103 unique audit client companies, i.e., audit firms maintained business relationships with 81 audit clients in both 2009 and 2010, and with 22 audit clients in only one of the two years. 
and hardware, including data vendors, telecom and internet services. Financial services business relationships involve banking (e.g., business accounts, loans, mortgages) and insurance services. Personnel business relationships involve services regarding hiring of temporary personnel, training, and salary administration. Carlease business relationships involve leasing of company cars. The other business relationships involve the remaining miscellaneous types of services, such as hospitality, consulting, and sponsoring. Panel B describes the industries in which the audit client companies involved in the business relationships with the audit firms are active. Panel $\mathrm{C}$ shows that 36 business relationships are maintained with public interest entities (PIEs, i.e., listed companies, banks, or insurance companies), and the remaining 148 business relationships with non-PIEs. Panel D shows that a majority of the business relationships, i.e., 85.9 percent, involve a Big 4 audit firm.

Table 1

\section{Descriptive Statistics for Business Relationships}

\section{Panel A: Types of Business Relationships}

Number of Business Relationships

\begin{tabular}{lrrr}
\cline { 2 - 4 } Type of Business Relationship & $\mathbf{2 0 0 9}$ & $\mathbf{2 0 1 0}$ & Total \\
\hline Facility services & 22 & 22 & 44 \\
Office building & 19 & 17 & 36 \\
ICT & 15 & 14 & 29 \\
Financial services & 10 & 12 & 22 \\
Personnel & 11 & 11 & 22 \\
Car lease & 8 & 6 & 14 \\
Other & 8 & 9 & 17 \\
Total & 93 & 91 & 184
\end{tabular}

Panel B: Number of Companies and Business Relationships per Industry Number of Business Relationships

\begin{tabular}{llrrr}
\cline { 2 - 4 } SIC Code & Industry Description & $\mathbf{2 0 0 9}$ & $\mathbf{2 0 1 0}$ & Total \\
\hline $010-199$ & Mining and Construction & 4 & 5 & 9 \\
$200-399$ & Manufacturing & 8 & 8 & 16 \\
$400-499$ & Transportation and Communication & 5 & 3 & 8 \\
$500-599$ & Trade & 13 & 15 & 28 \\
$600-699$ & Financials & 32 & 30 & 62 \\
$700-899$ & Services & 31 & 30 & 61 \\
& Total & 93 & 91 & 184 \\
\hline
\end{tabular}


Table 1 - continued

Panel C: Number of Companies and Business Relations per Type of Company

Number of Business Relationships

\begin{tabular}{lrrr}
\hline Type of Company & $\mathbf{2 0 0 9}$ & $\mathbf{2 0 1 0}$ & Total \\
\hline PIE & 17 & 19 & 36 \\
Non-PIE & 76 & 72 & 148 \\
Total & 93 & 91 & 184
\end{tabular}

\begin{tabular}{l|crr}
\hline Panel D: Number of Companies and Business Relations per Type of Audit Firm \\
$\begin{array}{l}\text { Number of } \\
\text { Type of Ausiness }\end{array}$ \\
\cline { 2 - 4 } & $\mathbf{2 0 0 9}$ & $\mathbf{2 0 1 0}$ & Total \\
\hline Big 4 & 81 & 77 & 158 \\
Non-Big 4 & 12 & 14 & 26 \\
Total & 93 & 91 & 184 \\
\hline
\end{tabular}

Second, I collected data for the 'untreated' or 'control' companies without business relationships with their audit firms. In order to construct a research sample of both treated and untreated observations, I follow Eshleman and Guo (2014b), Lawrence et al. (2011), and Boone et al. (2010) and use a propensity-score matching approach, developed by Rosenbaum and Rubin (1983), to match each business relationship observation to a similar observation with no business relationship. There are a number of reasons to choose a propensity-score matching approach over constructing a sample consisting of all Dutch companies. First, there may be a potential endogeneity problem, as the likelihood of an audit firm maintaining a business relationship with an audit client may very well be dependent on underlying variables that also determine audit fees. A first glance at the descriptive statistics for companies with a business relationship with their audit firm (as reported in Table 3 and further described in the next section), shows that these companies are for instance significantly larger (both in total assets and in number of subsidiaries), more highly leveraged, and more often listed at the two main stock exchanges indexes (i.e., the Amsterdam Exchange Index (AEX) and the Amsterdam Midkap Index (AMX)). These characteristics are also important in explaining audit fees (as described in the next section). Using a propensity-score matching approach addresses this endogeneity problem (Lawrence et al. 2011), as it attempts to minimize the variation in the company characteristics between treatment and control groups (Eshleman and 
Guo 2014b). ${ }^{12}$ Second, audit and non-audit fee data are not readily available, especially not for non-PIE companies, and need to be manually collected from AFM files. Lastly, the number of business relationships between audit firms and audit clients is naturally confined: an audit firm generally only needs a limited number of suppliers, i.e., mostly one, for each type of goods or services. ${ }^{13}$ Performing multivariate analyses on such a sample would likely result in low power tests. Therefore there is a need for a smaller sample in which the 'treated' observations are present in a higher proportion.

For all Dutch companies with sufficient financial statement data available in either the Orbis or Amadeus databases, the likelihood of a business relationship is modeled using the following logit regression: ${ }^{14}$

$$
\begin{aligned}
B R_{t}= & \beta_{0}+\beta_{1} \text { LNASSETS }_{t}+\beta_{2} \text { INVREC }_{t}+\beta_{3} L E V_{t}+\beta_{4} \text { ROA }_{t}+\beta_{5} \text { LOSS }_{t}+\beta_{6} \text { LISTED }_{t} \\
& +\beta_{7} \text { LNSUBS }_{t}+\beta_{8} \text { BIG }_{t}+\text { YEAR/INDUSTRY fixed effects }+\varepsilon
\end{aligned}
$$

All variables used in various tests are defined in Table 2.

\section{Audit Fee Analysis Sample}

After obtaining the fitted values from estimating equation (1), each business relationship observation is matched, without replacement, to four company-year observations without a business relationship with the closest fitted value. ${ }^{15}$ For observations of nonPIE companies, a three percent caliper distance is applied. For observations of PIE companies this restriction is not applied, to prevent losing too many PIE observations. ${ }^{16}$

12 An alternative method for dealing with endogeneity, is using a Heckman (1979) model. However, as pointed out by Lennox and Pittman (2010b, 236): "In the context of auditor choice, a researcher who wishes to use the Heckman (1979) model faces the often intractable task of identifying an independent variable that meets the following conditions: (a) it is exogenous, (b) it is a very powerful predictor of auditor choice in the first stage model, and (c) it does not affect the dependent variable in the second stage model." If one does not have such a variable, then the results from the Heckman model can be extremely sensitive to minor changes in the specification of the model (Lennox et al. 2012).

13 According to another AFM report published in 2010, there are 21,544 statutory audits performed in the Netherlands, of which 15,404 by the PIE audit firms included in this study (AFM 2010). This means that the 184 business relationships only account for a little over 1 percent of the total number of audits.

14 All independent variables are winsorized at the 1 and 99 percentile level to mitigate the effect of these extreme values.

15 I match each business relationship observation with four observations without business relationships in order to improve the reliability of the models. In a sensitivity test (untabulated), instead of matching each business relationship observation with four observations without a business relationship, I use a 1-on-1 matching. The regression tests on this reduced research sample of 364 observations lead to qualitatively the same results.

16 In a sensitivity test the three percent caliper distance is also applied to the entire sample, including the observations of PIE companies. By doing so, 22 business relationships with PIE audit clients (and their matched observations) are excluded from the sample, reducing the research sample to 810 observations. The regression tests on this reduced research sample lead to qualitatively the same results. 
Table 2

\section{Variable Definitions (In Alphabetical Order)}

\section{Variable}

$\triangle A R$

ASSETS

ATA

BIG4

$B R$

BR_CARLEASE

BR_FACILITY_SERVICES

BR_FINANCIAL_SERVICES

BR_ICT

BR_OFFICE_BUILDING

BR_OTHER

BR_PERSONNEL

CFO

FYAUDIT

INDUSTRY

\section{Definition}

A company's change in accounts receivable from year t-1 to year $t$, scaled by lagged total assets.

A company's total assets in thousand EUR.

A company's abnormal accruals, calculated using a variant of the performance-adjusted cross-sectional modified Jones (1991) model as described by Dechow et al. (1995) and Kothari et al. (2005) (see equation (2) for details).

An indicator variable equal to 1 if the company's financial statements are audited by a Big 4 audit firm, and otherwise 0 .

An indicator variable equal to 1 if there is a business relationship between the company and its audit firm.

An indicator variable equal to 1 if the business relationship involves leasing of company cars, and otherwise 0.

An indicator variable equal to 1 if the business relationship involves services and products regarding office facilities, such as office supplies, printing, cleaning, catering, security, energy, postal services, and otherwise 0 .

An indicator variable equal to 1 if the business relationship involves banking or insurance services, and otherwise 0 .

An indicator variable equal to 1 if the business relationship involves services regarding sales, development, or maintenance of software and hardware, including data vendors, telecom and internet services, and otherwise 0 .

An indicator variable equal to 1 if the business relationship involves services regarding development, construction, maintenance, or rental of office buildings, and otherwise 0 .

An indicator variable equal to 1 if the business relationship involves other services, such as hospitality, consulting, and sponsoring, and otherwise 0 .

An indicator variable equal to 1 if the business relationship involves services regarding hiring of temporary personnel, training, and salary administration, and otherwise 0 .

A company's cash flows from operations scaled by lagged total assets. In the regression analysis tests with absolute abnormal accruals, the absolute value of CFO is used as an independent variable. In the regression analysis tests with income-increasing or -decreasing abnormal accruals, the signed value of CFO is used.

An indicator variable equal to 1 if the company's audit firm is performing a first-time audit, and otherwise 0.

Vector of industry dummies (SIC 200-399: Manufacturing; SIC 400-499: Transportation, Communication, Electric, Gas, and Sanitary Services, SIC 500-599: Wholesale trade, SIC 600-699: Financial companies, SIC 700-899: Services. SIC 100-199 (Mining and construction) is the industry of reference).

A company's sum of inventory and receivables scaled by total assets. 
Table 2 - continued

\section{$L E V$}

LISTED

LNASSETS

LNAUDITFEE

LNNASFEE

LOSS

MAINEX

$P P E$

PPE_GROWTH

$\triangle R E V$

$R O A$

SALES

SALES_GROWTH

SALESVOL

SUBS

$T A$

Y2009
A company's total liabilities scaled by total assets.

An indicator variable equal to 1 if the company is publicly quoted; otherwise 0 .

A company's natural logarithm of total assets in thousand euros.

A company's natural logarithm of audit fees in euros paid by the company to the audit firm;

A company's natural logarithm of fees in euros paid by the company to the audit firm for other services than the statutory audit.

An indicator variable equal to 1 if the company reports a loss in both year $t$ and year $t-1$, and otherwise 0 .

An indicator variable equal to 1 if the company's shares are included in one of the two largest Dutch stock indexes (AEX and AMX), and otherwise 0 .

A company's gross property, plant, and equipment, scaled by lagged total assets.

A company's one-year growth in gross property, plant, and equipment from year $t-1$ to year $t$.

A company's change in sales from year $t-1$ to year $t$, scaled by lagged total assets.

A company's return on assets, defined as net income scaled by lagged total assets.

A company's sales.

A company's one-year growth in sales from year t-1 to year t.

A company's sales volatility, defined as the standard deviation of the change in a company's sales, scaled by average assets in the preceding three years.

A company's number of subsidiaries.

Total accruals, defined as a company's change in non-cash current assets minus the change in current liabilities excluding the current portion of long-term debt, minus depreciation and amortization, scaled by lagged total assets.

An indicator variable equal to 1 if the year is 2009, and otherwise 0 .

This approach leads to a sample of 920 observations for the audit fee analysis. Although any resulting differences between the business relationshipobservationsand observations without business relationships should reflect the 'treatment' effect and not pre-existing characteristics, and differences in means between these two groups should be sufficient to estimate the treatment effect, I follow Lawrence et al. (2011) and also use multivariate analyses to further control for any remaining characteristic imbalances between the two client groups as well as general cross-sectional characteristic variations. 


\section{Earnings Quality Analysis Sample}

Abnormal total accruals is an earnings quality measure commonly used as a proxy for the output-side of audit quality. DeFond and Zhang (2014) review and critique various audit quality proxies used in archival auditing research. They conclude that no single proxy paints a complete picture of audit quality and recommend researchers to use multiple proxies from different categories to take advantage of their strength and attenuate their weaknesses. Earnings quality measures attempt to measure how well reported earnings map into the company's underlying economic activities. Since the earnings quality measure used in this analysis, abnormal total accruals, is continuous, it captures variations in audit quality even in relatively small samples, and within samples with clients that not necessarily violate GAAP, and therefore appears to be well suited for measuring audit quality at a conceptual level.

To measure abnormal total accruals, the performance-adjusted cross-sectional modified Jones (1991) model as described by Dechow et al. (1995) and Kothari et al. (2005) is used. This model has also been used in prior accruals quality research in the Netherlands (e.g., Van de Poel and Vanstraelen 2011). The first step is to estimate the following OLS regression (all variables are defined in Table 2 ): ${ }^{17}$

$$
T A_{t}=\alpha_{0}+\alpha_{1}\left(1 / \operatorname{ASSETS}_{t-1}\right)+\alpha_{2}\left(\Delta R E V_{t}-\Delta A R_{t}\right)+\alpha_{3} P P E_{t}+\varepsilon
$$

Equation (2) is estimated by year and by three-, two-, or one-digit SIC codes conditional on having at least 10 companies in each SIC group. A company's unadjusted abnormal accruals are set equal to the difference between total accruals and the fitted normal accruals estimated by the appropriate residuals from equation (2). Subsequently, abnormal accruals are adjusted for performance as described in Kothari et al. (2005). To this end, companies are ranked within each industry-year group into ten groups based on their return-on-assets (ROA). Performance-adjusted abnormal total accruals (ATA) are the difference between the sample company's 'unadjusted abnormal accruals' and the median abnormal accruals for companies in the same industry-year-ROA decile. I analyze the absolute value of $A T A$, and income-increasing $(A T A>0)$ and income-decreasing abnormal accruals $(A T A<0)$ separately, since ex ante it is not clear what the direction of earnings management is, given that the sample includes both listed and private companies. Hence, companies are expected to exhibit both income-increasing and income-decreasing accruals (Warfield et al. 1995).

The abnormal total accruals are estimated using all companies in the Orbis database for which sufficient financial statement data are available. Similar to prior

17 Observations for which any value of the variables in equation (3) is above the 0.99 or below the 0.01 percentile of all companies are excluded from the calculation of parameter values for equation (3) to mitigate the effect of these extreme values on the calculation of 'expected' accruals. However, these companies are included in the final sample, after winsorizing extreme values. 
studies, financial companies with Standard Industrial Classifications (SICs) between 600 and 699 are excluded because computing discretionary accruals for these companies is problematic. Utility companies (SICs between 490 and 499) are also excluded because regulation may make the incentives to manage earnings different from the incentives in unregulated industries (e.g., Becker et al. 1998). This reduction in the research sample leads to a total of 592 observations for the earnings quality analysis.

\subsubsection{Audit Fee Model}

To test the formulated hypotheses $\mathrm{H} 1 \mathrm{a}$ and $\mathrm{H} 1 \mathrm{~b}$, i.e., the association between business relationships and audit fees, an audit fee model is estimated. Building on prior audit fee studies, I use the following audit fee model, with robust standard errors that are heteroscedasticity-consistent (White 1980):

$$
\begin{aligned}
& \text { LNAUDITFEE }_{t}=\beta_{0}+\beta_{1} \text { BR }_{t}+\beta_{2} \text { LNASSETS }_{t}+\beta_{3} \text { INVREC }_{t}+\beta_{4} L E V_{t}+\beta_{5} \text { ROA }_{t} \\
&+\beta_{6} \text { LOSS }_{t}+\beta_{t} \text { LISTED }_{t}+\beta_{8} \text { MAINEX }_{t}+\beta_{9} \text { LNSUBS }_{t}+\beta_{10} B I G 4_{t} \\
&+\beta_{11} \text { FYAUDIT }_{t}+\beta_{12} \text { LNNASFEE }_{t}+\text { YEAR } / \text { INDUSTRY fixed effects }+\varepsilon
\end{aligned}
$$

All variables used are defined in Table 2 . The audit fee model follows the structure originally introduced by Simunic (1980) in which audit fees are expected to depend on the treatment variable (i.e., $B R$ ), and control variables for client size (i.e., LNASSETS), client risk (i.e., INVREC, LEV, ROA, LOSS, LISTED, and MAINEX), client complexity (i.e., LNSUBS), auditor characteristics (i.e., BIG4, FYAUDIT, and LNNASFEE), and year and industry dummies. These control variables are found in prior work to be associated with audit fees (e.g., Simunic 1980; Palmrose 1986b; Langendijk 1997; Ashbaugh et al. 2003; Hay et al. 2006; Schelleman and Knechel 2010).

The dependent variable in equation (3), LNAUDITFEE, is the natural logarithm of the fees in euros in year $t$ paid by the client company to the audit firm for performing the statutory audit of its financial statements. I obtained audit fee information from the AFM's proprietary files. Audit firms have provided the AFM with excerpts from their client account records, including data on the fees charged to their audit clients. All fees charged for performing the statutory audit of the company's financial statements are considered audit fees. All other fees, including fees for audit-related engagements and fees for other services, are considered non-audit fees.

Prior research has found audit fees to be lower for companies that are financially more successful and companies that have a new auditor, and higher for larger, more complex, and riskier clients. Audit fees are also found to be higher for Big 4 audits, and when non-audit fees are higher. Therefore, the signs for the control variables $R O A$ and FYAUDIT are predicted to be negative, and positive for the remaining control variables, with the exception of the year and industry dummy variables, for which no sign is predicted. 
Furthermore, in order to test the individual effects of the different types of business relationships on audit fees, the variable $B R$ in equation (3) is replaced by individual dummy variables for the seven specific types of business relationships (see Table 1, Panel A).

\subsubsection{Earnings Quality Model}

To test the formulated hypotheses $\mathrm{H} 2 \mathrm{a}$ and $\mathrm{H} 2 \mathrm{~b}$ on the association between business relationships and earnings quality, I estimate an earnings quality model. In addition to the variable of interest, i.e., $B R$ measuring the presence of a business relationship, I include the following control variables found in prior studies to be associated with abnormal accruals (e.g., Dechow and Dichev 2002; Francis et al. 2013; Hribar and Nichols 2007; Young 1999): LNASSETS, to control for company size, $L E V$, to control for a company's leverage, CFO and LOSS, to control for a company's performance, SALES_ GROWTH, PPE_GROWTH, and SALESVOL, to control for a company's natural volatility of its accruals, LISTED, to control for a company's stock listing, and YEAR and INDUSTRY dummies. Hence the empirical model is as follows (all variables are defined in Table 2): ${ }^{18}$

$$
\begin{aligned}
& \mid \text { ATA }_{t} \mid, \text { ATA }_{t}>0 \text { or } A T A_{t}<0=\beta_{0}+\beta_{1} \text { BR }_{t}+\beta_{2} \text { LNASSETS }_{t}+\beta_{3} L E V_{t}+\beta_{4} C F O_{t} \\
&+\beta_{5} \text { SALES_GROWTH } H_{t}+\beta_{6} \text { PPE_GROWTH } H_{t}+\beta_{7} \text { SALESVOL }_{t}+\beta_{8} \text { LOSS }_{t} \\
&+\beta_{9} \text { LISTED } \\
&+ \text { YEAR/INDUSTRY fixed effects }+\varepsilon
\end{aligned}
$$

\subsection{Results}

\subsubsection{Descriptive Statistics and Univariate Results}

Table 3 presents the descriptive statistics of the company characteristics for the full sample (920 observations for the audit fee analysis in Panel A and 592 observations for the earnings quality analysis in Panel B). Furthermore, the descriptive statistics are presented for subsamples of observations with and without business relationships with their audit firms separately, including the t-statistics and significance levels of the differences between these two subsamples. The mean values of LNAUDITFEE are significantly higher for companies with business relationships with their audit firms ( $p=$ 0.000). This suggests a positive association between business relationships and audit fees (consistent with $\mathrm{H} 1 \mathrm{a}$ and not with $\mathrm{H} 1 \mathrm{~b}$ ). The mean values of ATA (absolute and signed) are not significantly different for the two subsamples (not consistent with either H2a or

18 Observations for which any value of the variables (dependent, test, and control variables) in equation (4) is above the 0.99 value or below the 0.01 value of all companies are winsorized to mitigate the effect of these extreme values. 

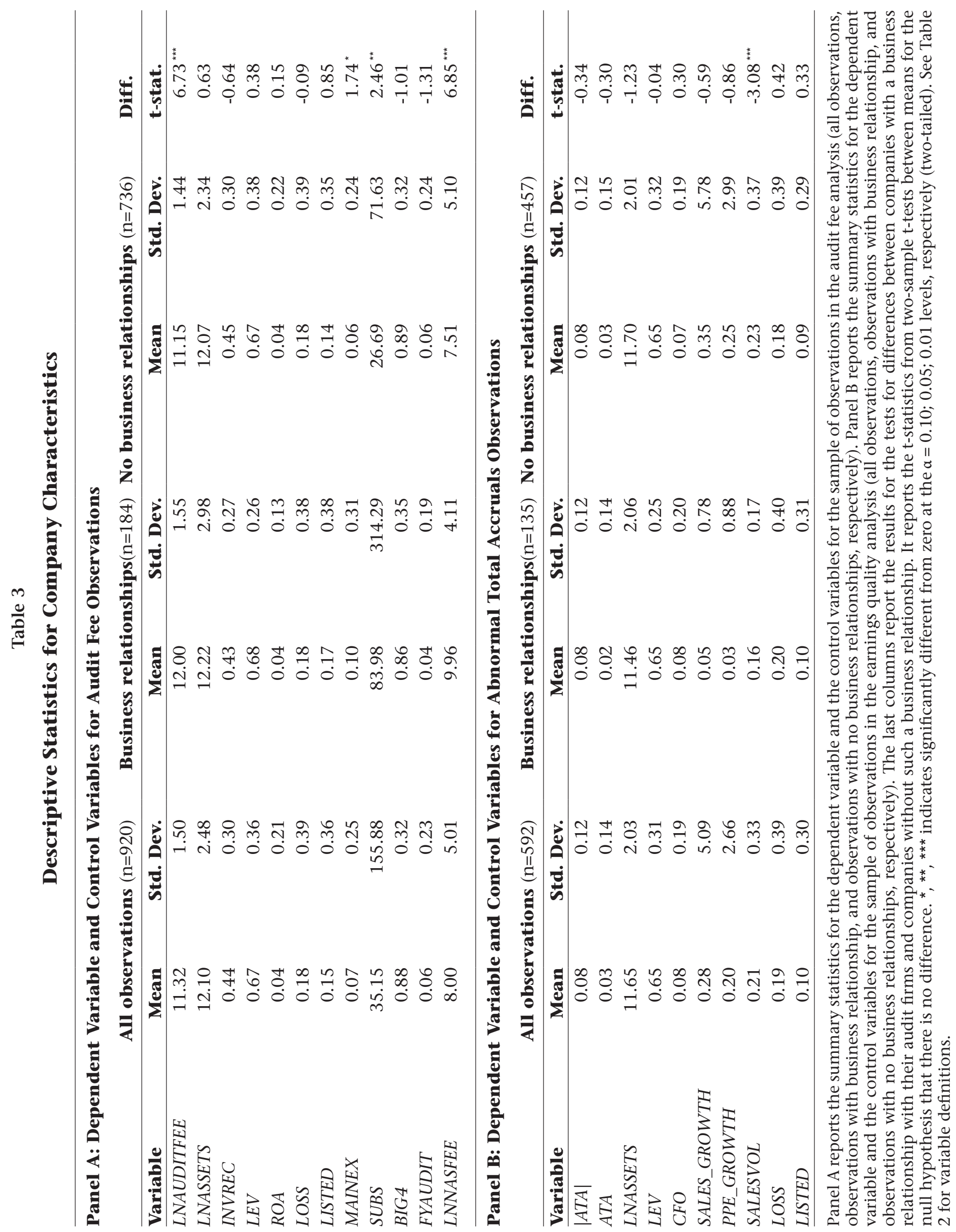


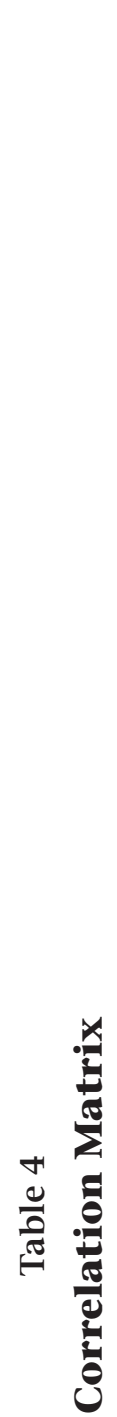

N

$=$

욱

$a$

$\infty$

$n$

6

ลูำ

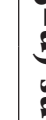

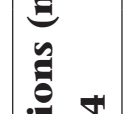

$+$

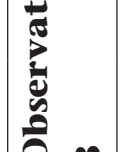

oิ $n$

里

N

e

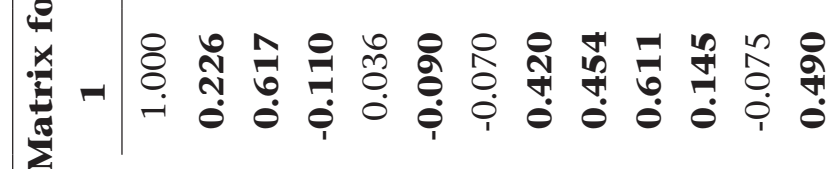

3

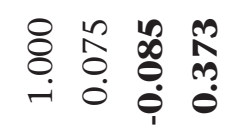

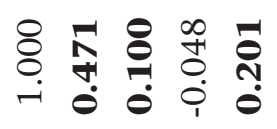

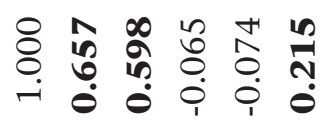

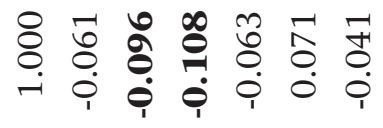

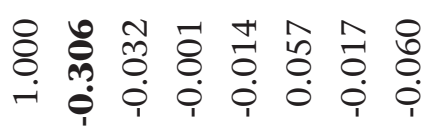

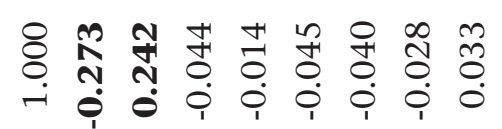

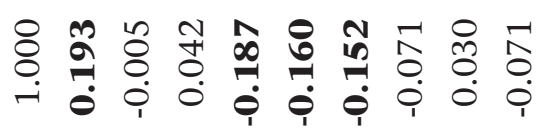

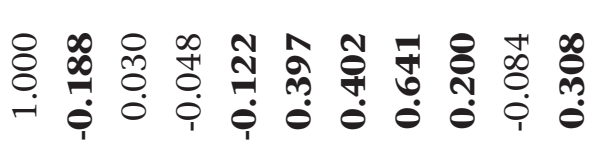

\& ปั กิ

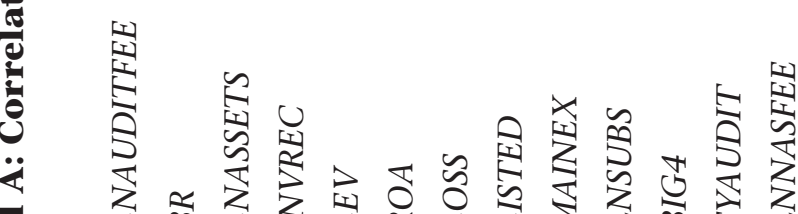

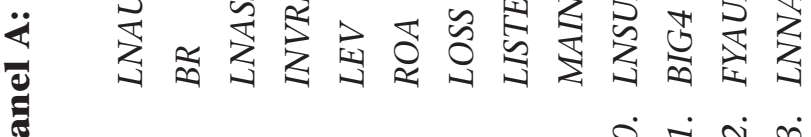

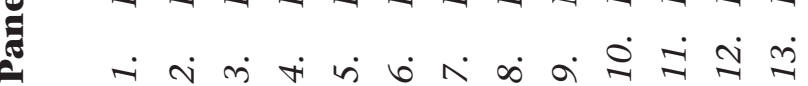

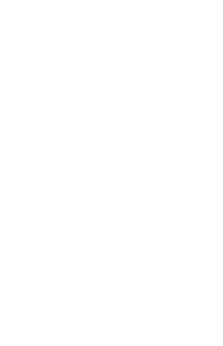

ลิ

în

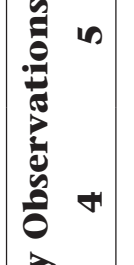

N

$\infty$

\begin{tabular}{lll}
8 & $m$ & $n$ \\
8 & 0 & 0 \\
\hdashline & 0 & 0 \\
-1 & 1
\end{tabular}

\begin{tabular}{lll}
0 & 0 \\
\hdashline & 0 \\
\hdashline & 0 \\
\hdashline & 1
\end{tabular}

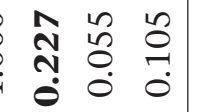

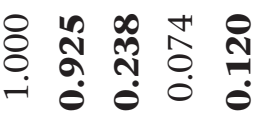

\&

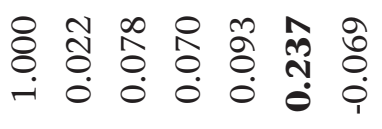

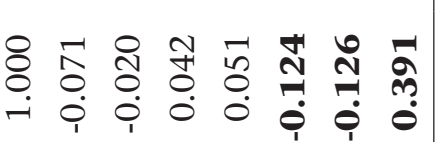

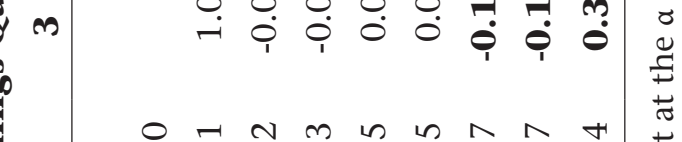

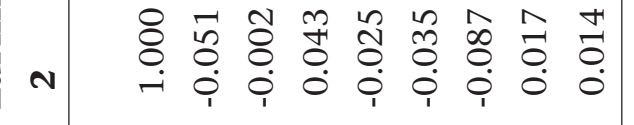

른

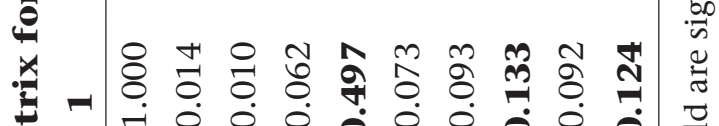

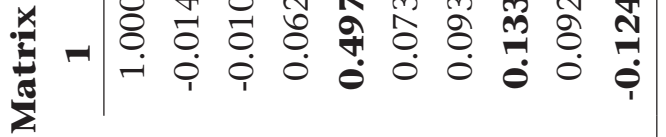

$\sum^{2}$
ق 
H2b). Further comparison of the business relationship and no business relationship subsamples shows that companies with business relationships with their audit firms are more often listed at the two main stock exchanges (MAINEX), have more subsidiaries (SUBS), pay higher non-audit fees to their audit firms (LNNASFEE), and have lower sales volatility (SALESVOL). The variables used to calculate the propensity score to match the 'treated' observations (i.e., companies with a business relationship with their audit firm) with 'untreated' observations (i.e., companies without such a business relationship), are not significantly different, except for the number of subsidiaries (SUBS). This suggests that the matching procedure was effective in forming a balanced sample of business relationships and no business relationships observations.

Table 4 presents the Pearson correlation coefficients between the variables included in the audit fee model (Panel A) and the earnings quality model (Panel B). The absence of very high correlations and (untabulated) average VIF values well below the commonly used threshold of 10 (2.01 for the audit fee analysis and 1.73 for the earnings quality analysis), show that the risk of bias in the multivariate analyses due to multicollinearity is minimal (Hair et al. 2006).

\subsubsection{Multivariate Results}

Table 5 presents coefficient estimates and t-values for the audit fee model presented in equation (3). Column (1) includes the dummy variable $B R$, which is 1 if there is a business relationship between the audit firm and the audit client, and otherwise 0 . In Column (2) the dummy variable $B R$ is replaced by seven individual dummy variables for the different types of business relationships. Both regressions are statistically significant $(p=0.000)$ and explain a relatively large proportion of the variation in audit fees (adjusted R-squared $=0.578$ and 0.577 , respectively). The coefficient for the variable of interest in Column $(1), B R$, is positive and significant $(p=0.000)$. This suggests a significant positive association between the occurrence of a business relationship and the level of audit fees.

The regression in Column (2) distinguishes among the different types of business relationships. The coefficients for all seven types of business relationships are positive and significant $(p<0.05$ for personnel services and car leasing and $p<0.01$ for the other types of business relationships). This suggests that the overall positive association between the occurrence of a business relationship and the level of audit fees is not dependent on the type of business relationship. ${ }^{19}$

19 To examine whether the association between audit fees and the type of business relationships is different for the various types of business relationships, I re-performed the regression analysis of Column (2) in Table 5 for the business relationship observations only $(\mathrm{n}=184)$ (with BR_OTHER as reference). Unreported results show that only the business relationships regarding the office buildings are significantly associated with higher audit fees compared to the other types of business relationships. The insignificant coefficients for the other types of business relationships indicate that these are all equally associated with audit fees. 
Table 5

\section{Multiple Regressions for Business Relationships and Types and Audit Fees}

Dependent Variable: LNAUDITFEE

(1)

(2)

\begin{tabular}{|c|c|c|c|c|c|}
\hline Independent Variables & Pred. Sign & Coef. & t-stat. & Coef. & t-stat. \\
\hline \multicolumn{6}{|l|}{ Business Relationship Variables } \\
\hline$B R$ & $?$ & 0.570 & $7.52^{\star \star \star}$ & & \\
\hline BR_FACILITY_SERVICES & $?$ & & & 0.474 & $3.32^{* * *}$ \\
\hline BR_OFFICE_BUILDING & $?$ & & & 0.865 & $4.26^{* * *}$ \\
\hline BR_ICT & $?$ & & & 0.511 & $3.80^{* * *}$ \\
\hline BR_PERSONNEL & $?$ & & & 0.332 & $2.13^{* *}$ \\
\hline BR_FINANCIAL_SERVICES & $?$ & & & 0.672 & $3.19^{* * *}$ \\
\hline BR_CARLEASE & $?$ & & & 0.517 & $2.30^{* *}$ \\
\hline BR_OTHER & $?$ & & & 0.514 & $3.61^{* * *}$ \\
\hline \multicolumn{6}{|l|}{ Control Variables } \\
\hline LNASSETS & + & 0.193 & $9.85^{\star \star \star}$ & 0.191 & $9.56^{\star \star \star}$ \\
\hline INVREC & + & 0.154 & 1.20 & 0.132 & 1.03 \\
\hline$L E V$ & + & 0.064 & 0.63 & 0.064 & 0.62 \\
\hline$R O A$ & - & -0.406 & $-2.11^{* *}$ & -0.423 & $-2.19^{* *}$ \\
\hline LOSS & + & 0.009 & 0.09 & 0.004 & -0.04 \\
\hline LISTED & + & 0.006 & 0.05 & 0.015 & 0.12 \\
\hline MAINEX & + & 0.928 & $6.13^{* \star *}$ & 0.931 & $6.06^{* * *}$ \\
\hline LNSUBS & + & 0.200 & $6.78^{* * *}$ & 0.199 & $6.53^{* * *}$ \\
\hline$B I G 4$ & + & 0.236 & $2.18^{* *}$ & 0.250 & $2.30^{* *}$ \\
\hline FYAUDIT & - & -0.014 & -0.07 & -0.005 & -0.03 \\
\hline LNNASFEE & + & 0.073 & $9.21^{\star * *}$ & 0.073 & $9.23^{* * *}$ \\
\hline Constant & $?$ & 7.147 & $23.90^{* * *+}$ & 7.116 & $22.72^{* * *}$ \\
\hline Fixed effects & & \multicolumn{2}{|c|}{ INDUSTRY/YEAR } & \multicolumn{2}{|c|}{ INDUSTRY/YEAR } \\
\hline Observations & & & 920 & & 920 \\
\hline F-stat. & & & $78.24^{* * *}$ & & $58.82^{* * *}$ \\
\hline Adjusted $\mathrm{R}^{2}$ & & & 0.578 & & 0.577 \\
\hline
\end{tabular}

This table reports the multiple regression results for the audit fee model presented in equation (3). In Column (1), the variable of interest is the presence of a business relationship (BR), and in Column (2), the variables of interest are the seven types of business relationships. The coefficients estimates and t-values are based on robust standard errors that are White's (1980) heteroscedasticity-consistent. ${ }^{*},{ }^{* *}$, *** indicates significant at the $\alpha=0.10 ; 0.05 ; 0.01$ level, respectively (two-tailed). See Table 2 for variable definitions. 
Regarding the control variables, audit fees are significantly higher for companies that are larger $(p=0.000)$, are listed at one of the main exchanges $(p=0.000)$, have more subsidiaries ( $p=0.000)$, are audited by a Big 4 auditor $(p=0.030)$, and purchase more non-audit services $(p=0.000)$. Audit fees are significantly lower for companies with higher return on assets $(p=0.035)$. All significant control variables have signs as previously predicted. No significant associations were found for inventories and receivables over total assets, leverage, loss, listing, and first-year audits.

Overall, the results presented in Table 5 support H1a and not H1b. They show that there is a positive association between the presence of a business relationship and audit fees. This suggests that audit firms are extending their audit effort and/or are charging a premium in order to safeguard their independence which may be threatened by the business relationship or compensate for any losses they may incur from such a threat in the future.

Table 6 presents coefficients estimates and t-values from the earnings quality model in equation (4). Columns (1)-(3) present results of tests of the association between business relationships and abnormal accruals (ATA) using a performance-adjusted modified Jones model (absolute, income-increasing $(A T A>0)$, and income-decreasing $(A T A<0)$, respectively) with $B R$ as independent variable of interest. The coefficients for $B R$ areinsignificant, suggesting noassociation between the presence of abusiness relationship and earnings quality. Columns (4)-(6) present results of tests of the associations between the different types of business relationships and abnormal total accruals (absolute, income-increasing $(A T A>0)$, and income-decreasing $(A T A<0)$, respectively). The coefficients for the business relationships involving ICT services and car leases are negative and significantly different from 0 ( $p=0.063$ and 0.007 respectively) in the regression on absolute ATA. In the regression on income-increasing ATA only the coefficient for the business relationships involving car leases is negative and significantly different from 0 ( $p$ $=0.015)$. These results suggest a negative association between the presence of such a business relationship and abnormal total accruals. The coefficients for the other types of business relationships are not significant.

In Table 7 the analyses on audit fees and earnings quality are re-performed taking into consideration the combination of business relationships with non-audit services. The table presents the coefficients estimates and $t$-values for the variables of interests. The results for the control variables are unreported for brevity. First, separate tests were performed for the observations with above- and below-median non-audit fees relative to audit fees. For the audit fee model (Columns (1) and (2)), the results are qualitatively similar to those presented in Table 5 . The presence of a business relationship is associated with higher audit fees, irrespective of the level of non-audit fees relative to audit fees. For the earnings quality model, the results in Column (4) show the coefficient for $B R$ to be significantly negative ( $p=0.034)$ suggesting a negative association between the presence of a business relationship and abnormal total accruals for observations with high nonaudit fees relative to audit fees. For observations with below-median non-audit fees $B R$ is 


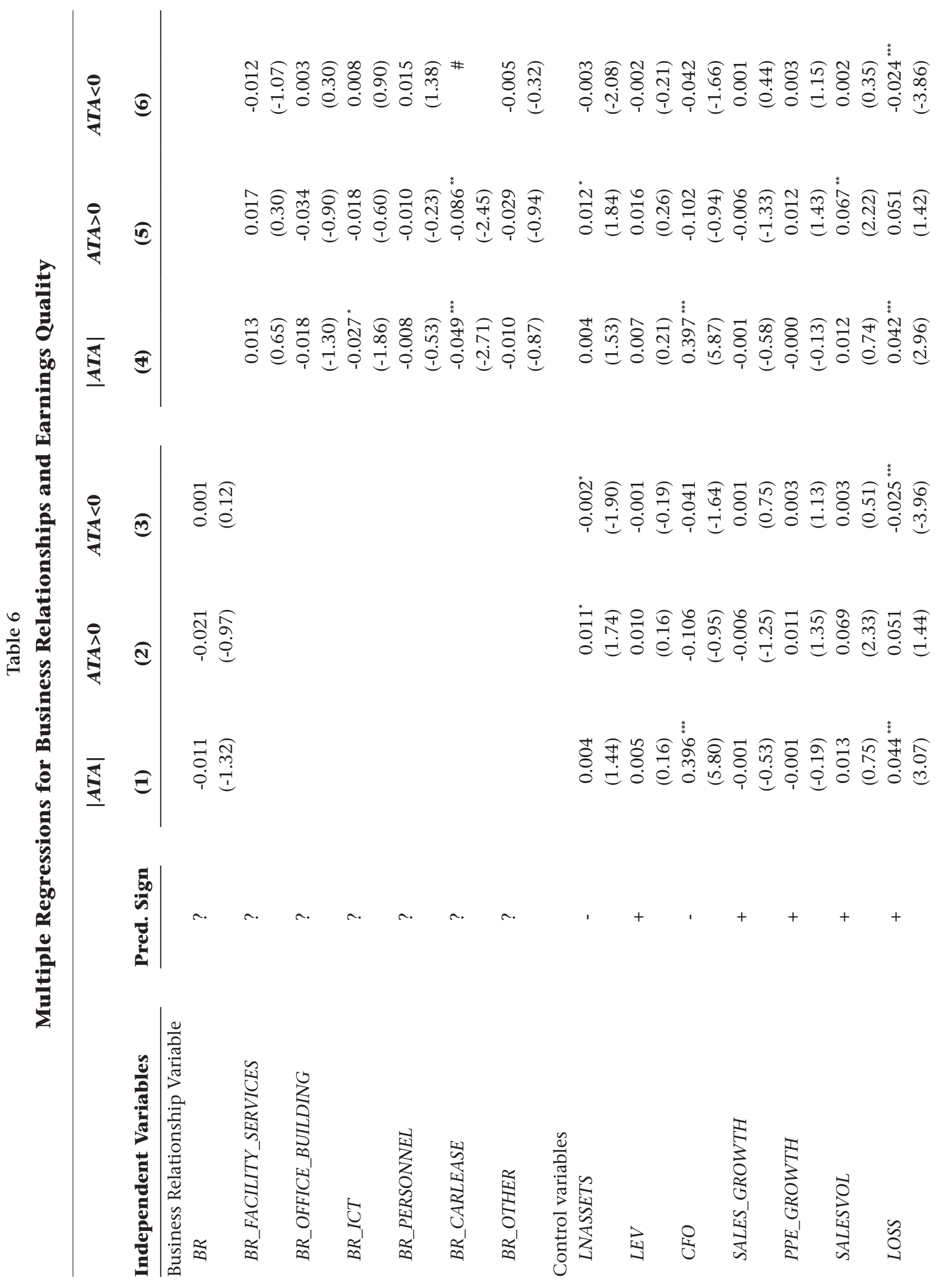




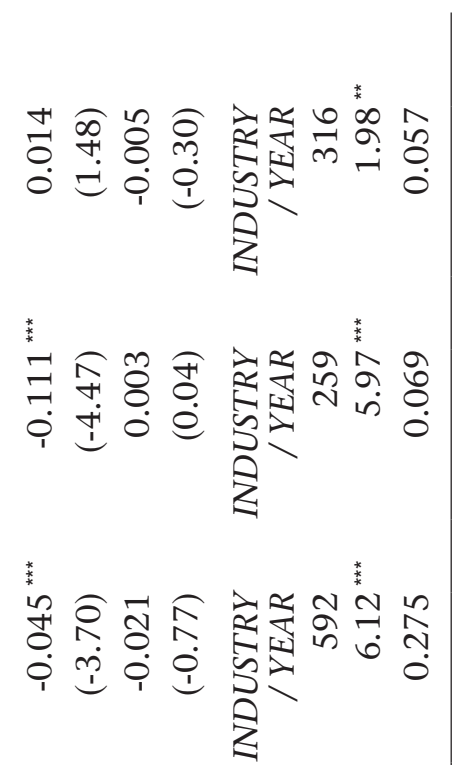

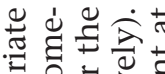

원.

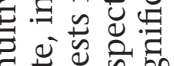

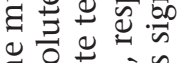

E

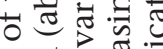

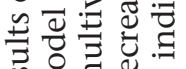

象

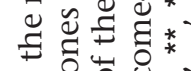

芉 응

政素

a:

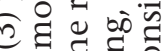

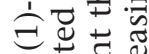

ปิ

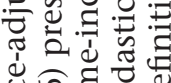

论

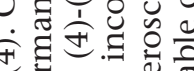

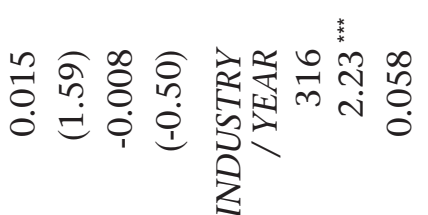

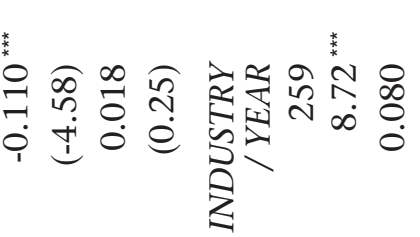

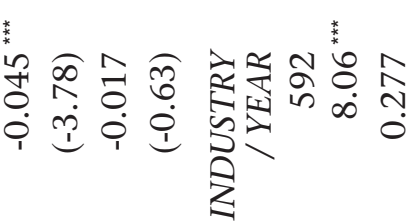

政

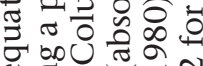

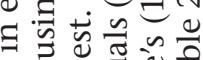

중

过怘范

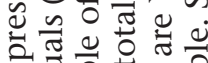

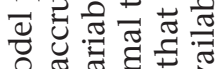

중

저응

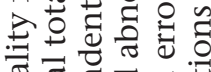

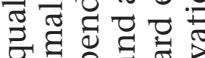

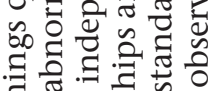

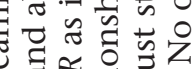

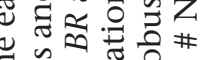

象象

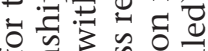

$\sim$ 记

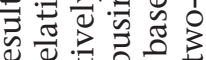

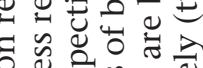

० क्षे

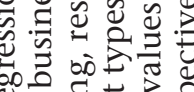

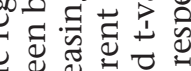

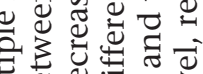

0 :

ปี 宅壱

记

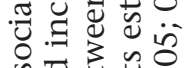

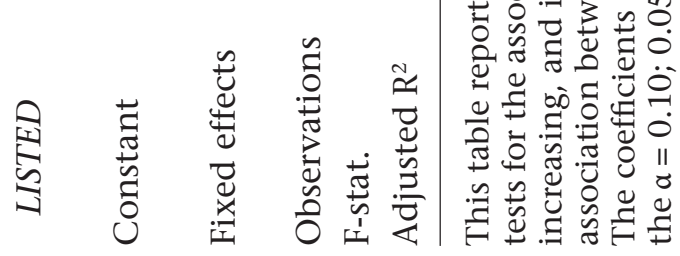




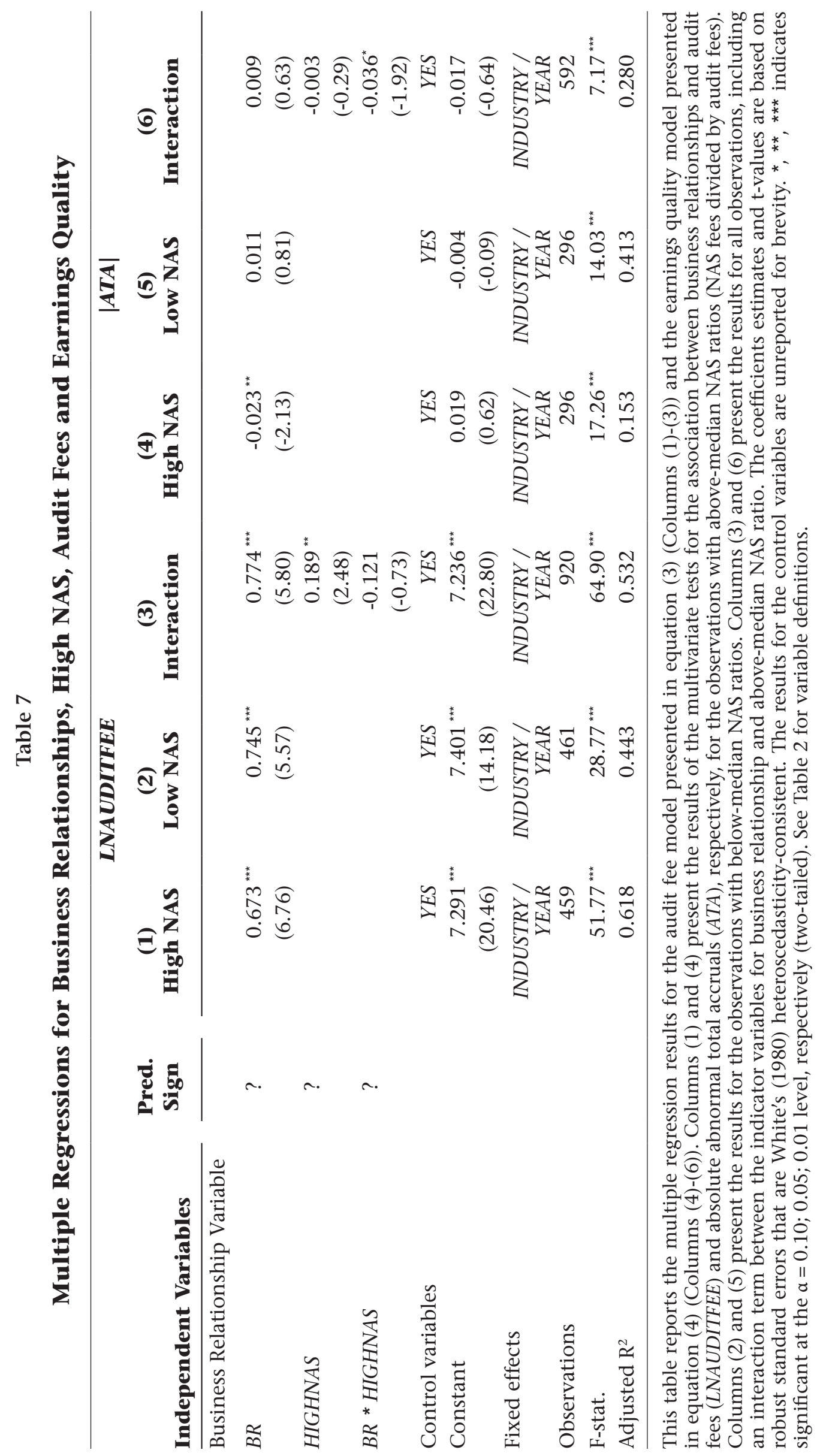


insignificant (Column (5)). Second, tests were performed on the full sample including an interaction term between the presence of a business relationship and a dummy variable equal to 1 if the non-audit fees relative to audit fees are above median (HIGHNAS). For the audit fee model (Column (3)), the coefficients for BR and HIGHNAS are significant, while the coefficient for the interaction term is insignificant. This suggests that both a business relationship and high non-audit fees relative to audit fees are associated with higher audit fees, but there appears to be no interaction effect. For the earnings quality model (Column (6)), the coefficient for the interaction term is significantly negative $(p=0.055)$.

Overall, the results presented in Tables 6 and 7 provide some support for $\mathrm{H} 2 \mathrm{a}$ and no support for H2b. The results show that, while audit fees are consistently higher in the presence of a business relationship, abnormal total accruals appear to be mostly unchanged, except when the business relationship coincides with high non-audit fees relative to audit fees. For those observations, abnormal total accruals are found to be lower, indicating higher earnings quality. This suggests that the increase in audit fees appears to be due to an increase in audit effort, particularly when the independence threat is larger due to simultaneous higher non-audit fees. However, for the observations with a business relationship and lower non-audit fees, the results provide no support for either $\mathrm{H} 2 \mathrm{a}$ or $\mathrm{H} 2 \mathrm{~b}$ and therefore do not completely rule out alternative explanations for higher audit fees, such as the audit firm charging a risk premium to the audit client with whom it maintains a business relationship. ${ }^{20}$

\subsubsection{Sensitivity Analyses}

A number of sensitivity analyses were conducted to determine if the results are robust. The results are summarized below.

\section{High Accrual Companies}

H1a incorporates the expectation that increased risk, as caused by a business relationship, will be associated with higher audit fees. Prior studies show that clients' accruals pose a risk to the auditor, since high-accrual companies have greater potential for asset realization problems and, in more extreme cases, going concern problems (Francis and Krishnan 1999). Hribar et al. (2014) find auditors to increase both audit hours and audit fees in cases where the auditors perceive a client's accounting quality to be low (i.e., clients with high accruals). Based on these prior findings, it may be that the positive

20 Church et al. $(2015,228)$ provide some explanation for why one might find different results for different audit quality proxies: "Our examination of experimental studies suggests that cognitive and motivational biases have the potential to impair independence and, consequently, weaken the audit process. By comparison, our examination of archival studies fails to definitively link test variables (i.e., auditor fees and lengthy auditor tenure) with evidence of compromised independence. Taken as a whole, the findings suggest that, although judgmental biases may hinder the audit process, such biases do not necessarily degrade audit outputs." 
association between business relationships and audit fees is primarily driven by highaccrual audit clients.

As a sensitivity test, the audit fee regressions (untabulated) are performed separately for audit clients with income-increasing or income-decreasing abnormal total accruals, and with above-median or below-median absolute abnormal total accruals. ${ }^{21}$ The coefficient for the variable $B R$ is positive and significant in all these tests. Furthermore, a fifth regression is performed on the full sample including an interaction term between the presence of a business relationship and a dummy variable equal to 1 if the audit client's absolute abnormal total accruals are above median. In this test, only the coefficient for $B R$ is positive and significant. The coefficient for the interaction term is insignificant. This suggests that audit fees are higher in the presence of a business relationship, irrespective of the level of abnormal total accruals. Overall, these findings suggest that the positive association between business relationships and audit fees is not primarily driven by high-accrual audit clients.

For the earnings quality analysis, in addition to the separate regression tests for income-increasing and income-decreasing abnormal total accruals already presented in Table 6, additional regression tests are performed for above-median and below-median absolute abnormal total accruals. In neither of these tests (untabulated) is the coefficient for $B R$ significant. However, the coefficient for $B R$ is found to be negative and significant for the observations with both above-median absolute abnormal total accruals and above-median non-audit fees relative to audit fees, consistent with the results in Table 7.

\section{Audit Firm Size}

The research sample used in this study includes companies audited by 12 audit firms with a license to perform statutory audits for both PIEs and other companies. ${ }^{22}$ These 12 audit firms include the Big 4 and mid-tier network firms as well as a few relatively small local audit firms. Big $\mathrm{N}$ auditors are generally found to charge on average higher audit fees to their clients (e.g., Craswell et al. 1995; Ettredge and Greenberg 1990; Francis and Simon 1987). In addition, prior research has shown that audit quality is not homogeneous across audit firms and that the largest firms, i.e., the Big $\mathrm{N}$ audit firms, provide higherquality audits than smaller, non-Big N, audit firms (e.g., Boone et al. 2010; Francis 2004; Francis and Krishnan 1999; Becker et al. 1998). In order to test whether the results hold throughout the entire sample or are primarily driven by the Big 4 observations, the following sensitivity tests are performed.

First, the regression of equation (3) is estimated separately for Big 4 audit clients and for non-Big 4 audit clients to test whether the positive association between business relationships and audit fees as found for the full sample holds for these two subsamples.

21 Abnormal total accruals are estimated using the performance-adjusted cross-sectional modified Jones model described before.

22 Three of the 15 audit firms with a PIE license included in the AFM review indicated that they maintained no business relationships with audit clients. 
Untabulated results show that the coefficient of $B R$ is positive and significant for both Big 4 audit clients and non-Big 4 audit clients ( $p=0.000$ and 0.007 respectively). This suggests that Big 4 and non-Big 4 auditors respond similarly to the presence of a business relationship with an audit client. In a further analysis on the full sample, the Big 4 dummy variable is interacted with the business relationship dummy variable. The coefficient for this interaction term is insignificant and the coefficients for the business relationships and Big 4 variables are both positive and significant ( $p=0.001$ and 0.067 respectively). This suggests that, while the presence of a business relationship and Big 4 auditors are both individually associated with higher audit fees, there appears to be no specific Big 4 effect regarding the association between business relationships and audit fees.

The same tests are performed for the earnings quality analyses of equation (4) presented in Table 6 . No significant association between business relationships and earnings quality was found in these tests. For the analyses presented in Table 7, separate regressions for Big 4 and non-Big 4 observations show that the results hold only for the Big 4 observations. However, the insignificant results for the (relatively few) non-Big 4 observations may be due to a lack of power.

\section{Public Interest Entities}

In Dutch audit regulation an important distinction is made between the audits for PIEs (i.e., listed companies, banks and insurance companies) and non-PIE audit clients. For audits of PIEs, additional standards and in particular additional independence requirements apply. Since the audits of PIEs are arguably under higher scrutiny of both the audit oversight body and the general public, I test whether the results hold throughout the entire sample or are primarily driven by PIE client observations. In both separate audit fee regressions for PIE and non-PIE audit client observations, $B R$ is positive and significant $(p=0.000)$. In the regression for the full sample including the interaction between $B R$ and a PIE dummy, $B R$ is still positive and significant, while both PIE and the interaction between $B R$ and $P I E$ are insignificant. These results suggest that there is no specific PIE effect in the association between business relationships and audit fees.

For the earnings quality analysis, $B R$ is found to be consistently insignificant. In the regression for the full sample with the interaction between $B R$ and $P I E$, only the coefficient for PIE is negative and significant $(p=0.001)$, indicating that while business relationships appear to have no association with earnings quality, the abnormal total accruals of PIE audit clients are significantly lower than those of non-PIE audit clients. For the analyses presented in Table 7, separate regressions for PIEand non-PIEobservations show that the results hold only for the non-PIE observations. However, the insignificant results for the (relatively few) PIE observations may be due to a lack of power.

\section{Demand for Audit Quality}

Agency theory provides an explanation of why different levels of audit quality are demanded. There are economic incentives for some companies to demand higher quality audits, even though these audits cost more than lower quality audits (Francis 
1984). Indeed, Lennox and Pittman (2011) find that companies with a low demand for audit quality were only passively complying with mandatory audit requirements, which was evident in their attempts to reduce costs through auditor choice and fees. Further, Griffin et al. (2010) find that companies with a high demand for audit quality, i.e., companies with high free cash flows and low growth opportunities, are charged higher audit fees by their auditors. Based on these prior findings, it may be that the positive association between business relationships and audit fees is primarily driven by companies with a higher demand for audit quality.

A dummy variable is constructed to distinguish companies with a higher versus lower demand for audit quality (HIGHDEM). This dummy variable is equal to 1 if the company's values for total assets, leverage, ratio of inventory, receivables and payables to total assets, sales growth, and number of shareholders, are above the median for at least three of these values. These items are expected to be indicative of higher agency costs leading to a higher demand for audit quality. Subsequently, the audit fee regressions are estimated separately for audit clients with a higher demand for audit quality and for audit clients with a lower demand for audit quality to test whether the positive association between business relationships and audit fees as found for the full sample holds for these two subsamples. The coefficient of $B R$ is positive and significant in both regressions (untabulated). In a third audit fee regression (untabulated), the high demand dummy variable is interacted with the business relationship dummy variable. The coefficient for this interaction term is insignificant, implying that the auditor's response to the presence of a business relationship with an audit client is not dependent on the audit client's demand for audit quality. In similar sensitivity tests for the earnings quality analysis, $B R$ is found to be consistently insignificant.

\section{Monetary value of business relationships}

To further test the robustness of the results, I use two alternative measures for business relationships. First, the $B R$ dummy variable used in the analyses is replaced by the natural logarithm of the monetary values involved in the business relationships. These concern the fees paid for goods or services provided by audit clients. ${ }^{23}$ Second, the $B R$ dummy variable is replaced by the monetary values involved in the business relationships scaled by the audit firm's total revenue (i.e., a measure for audit firm size). Untabulated results show the same outcomes for both alternative measures for business relationships, both for the audit fee and the earnings quality analyses.

23 And in case of financial companies (only included in the audit fee analysis) the amounts of money borrowed by the audit firm from the audit client that is a bank, or the amounts of insurance premium paid by the audit firm to the audit client that is an insurance company. 


\subsection{Conclusion}

This paper investigates how audit firms respond to the existence of a business relationship with an audit client, in terms of adjusting their audit efforts or risk premiums, by examining the association of the business relationship with audit fees and earnings quality. For all Dutch companies audited by one of the audit firms with a so-called PIE license, a propensity-score matching approach is used to construct a sample of all Dutch companies maintaining a business relationship with their audit firm matched with companies without such business relationships. Data on business relationships and audit fees were obtained from the proprietary files of the Dutch audit oversight body. The results show that audit fees are higher in the presence of an auditor-client business relationship. Further, results from the analysis of abnormal total accruals suggest that the increase in audit fees appears to be at least partly due to an increase in audit effort. Results show some evidence of a business relationship being associated with higher earnings quality, particularly in those situations where the business relationship coincides with high non-audit fees relative to audit fees, suggesting that increased audit fees are likely explained by increased audit effort or quality control safeguards. These results are robust to a number of sensitivity tests on cross-sectional subsamples (e.g., based on the audit firm size (Big 4 or non-Big 4), type of audit client (PIE or non-PIE), demand for audit quality, and client risk), as well as for an alternative measure of business relationships (i.e., the monetary value of these business relationships) and alternative matching methods.

Overall, the results suggest that audit firms respond to the circumstances in which they maintain a business relationship with an audit client, most likely by adjusting their audit efforts, resulting in higher audit fees and higher earnings quality. No evidence of impaired independence is found, which would likely have resulted in lower audit fees and lower earnings quality.

I acknowledge a number of limitations in my analyses. An important disadvantage of using audit fees as the dependent variable is that in addition to audit effort, audit fees also measure the auditor's risk premium for expected legal liability (Simunic 1980) as well as audit efficiency (e.g., Knechel and Sharma 2012), which may be difficult to entangle. Furthermore, Johnstone and Bedard $(2001,2003)$ argue that audit effort itself is endogenous: in addition to charging a risk premium, the auditor responds to higher audit risk by increasing audit effort. The second dependent variable, abnormal total accruals as a proxy for earnings quality, also has a number of limitations, including measurement error. Although measurement error may prevent incorrect significant associations, it is problematic when conclusions are drawn based on insignificant associations (e.g., DeFond and Zhang 2014). Finally, since earnings quality is influenced by factors other than audit quality, low audit quality will not necessarily be associated with low earnings quality (Gaynor et al. 2015).

There are also some limitations caused by the use of the propensity-score matching approach to construct the research sample (e.g., Lawrence et al. 2011). For instance, 
employing a matching approach results in examining subsamples of the full population. Therefore, findings may not be generalizable to the full population. Further, although the propensity-score matching approach addresses endogeneity problems (e.g., Lawrence et al. 2011; Eshleman and Guo 2014a), some endogeneity bias may remain.

Finally, the results do not completely rule out alternative explanations for higher audit fees. Alternatively, or simultaneously, an audit firm in a business relationship with its audit client may be charging a risk premium to that audit client. Furthermore, the existence of a business relationship between an audit firm and its audit client may be indicative of a reciprocal trust relationship in which both parties hold back on fierce price negotiations and allow each other to charge relatively higher fees. A higher audit fee may also be a way of signaling to the market that even though the business relationship poses a threat, the quality of the audit is ensured. Future research may attempt to disentangle the different causes for audit fees to change, such as audit effort, risk premiums, or audit efficiency, and to find additional control variables to alleviate the potential endogeneity problems. Furthermore, research could expand the literature on auditor independence by exploring the other types of independence threats covered by the Code of Ethics, such as financial interests, family and personal relationships, gifts and hospitality, and actual or threatened litigation. 
Chapter 4

\section{Audit Firm Governance and Audit Firm Quality: \\ An Examination of Audit Quality Indicators'} Vanstraelen. I thank Eva Bouwmans for data assistance and research cooperation. 


\begin{abstract}
This study examines the association between audit firm governance characteristics and three firm-level output measures of audit quality: (a) stakeholder dissatisfaction; (b) regulatory attention; and (c) audit market exit. The purpose is to identify audit quality indicators and increase the understanding of audit firms and their governance. Audit firm governance is operationalized by constructing organizational and quality control variables based on data obtained from the proprietary files of the Dutch public oversight body. Using the population of Dutch audit firms licensed to perform statutory audits over the period 2009-2014, the results show that several audit firm governance characteristics are associated, albeit to a different extent, with the three firm-level output measures of audit quality. Additional tests show that the informational value of the audit firm governance characteristics has increased over time. This study contributes to the growing literature on audit firm governance characteristics and audit quality indicators.
\end{abstract}




\subsection{Introduction}

Audit firm governance has become an important issue on the agenda of regulators, standard setters and public oversight bodies. It is a broad concept which relates to factors likegovernancestructure, qualitycontrolpolicies, humanresourcepolicies, independence and ethics of the audit firm (IOSCO 2009). The governance of an audit firm is expected to have a significant influence on the audit quality delivered by that firm. Regulation has been introduced including requirements for audit firm governance (e.g., The SarbanesOxley Act of 2002 (U.S. House of Representatives 2002), Directive 2006/43/EC on Statutory Audits of Annual and Consolidated Accounts (European Union 2006), and the Audit Firm Governance Code in the U.K. (ICAEW/FRC 2010)). Increasing transparency with regard to the governance and professional practices of audit firms, particularly in the form of publishing audit quality indicators and thereby increasing the availability of data on audit firm characteristics, has been on the agendas of several standard-setters, regulators, and legislators (e.g., PCAOB 2013; IOSCO 2009; ACAP 2008; FRC 2008; European Union 2006, Article 40). ${ }^{2}$ The purpose of the transparency recommendations is to increase market participants' ability to observe audit quality, thus enabling differentiation among audit firms on the basis of publicly available data. Audit quality indicators are expected to benefit auditors, issuers, and financial statement users by providing indicators of audit quality that improve observability of audit processes (Martin 2013), provide incentives for firms to increase audit quality (Bedard et al. 2010), and increase competition. In the words of James R. Doty, PCAOB Chairman, in his statement on the PCAOB's Concept Release on Audit Quality Indicators (PCAOB 2015):

"In an environment where all audits look alike on paper, it should be no surprise that there is considerable pressure and competition on the basis of fees. With more information about the inputs to audits, I hope to balance that pressure with more competition on quality as well."

In response to recent calls for more transparency, a number of jurisdictions (including the E.U.) now require audit firms with public interest entities (PIEs) as audit clients, i.e., listed companies, insurance companies, and credit instituations, to publicly disclose information on their governance practices. However, research on audit firm governance, and its association with audit quality in particular, is considered important (e.g., Bedard et al. 2008; Maijoor and Vanstraelen 2012), but thus far limited (e.g., Jenkins et al. 2008; McNair 1991; Abdel-khalik and Solomon 1988), partly due to the limited availability of data on (governance) characteristics of audit firms (Francis 2011). This study identifies audit quality indicators using audit firm governance characteristics, and links those

2 In November 2015, the Federation of European Accountants published an information paper with an overview of audit quality indicators initiatives by nine different organizations worldwide, including regulators, oversight bodies, professional bodies, and audit firms (FEE 2015). 
characteristics to three distinct audit firm-level output measures of audit quality: (a) stakeholder dissatisfaction (i.e., the total number of complaints and claims filed directly to the audit firm, complaints filed with the disciplinary court for auditors, and other legal proceedings); (b) regulatory attention (i.e., the number of inspections and sanctions by the public oversight body); and (c) audit market exit.

This study contributes to the emerging literature on audit quality indicators and audit firm governance by providing the first descriptive analysis of audit firm governance (i.e., organizational and quality control) characteristics associated with firm-level output measures of audit quality. Even though detailed information about large samples of audit firms is usually difficult to obtain (Casterella et al. 2010), this study includes all active audit firms on the Dutch statutory audit market. ${ }^{3}$ I obtained the governance characteristics from the proprietary files of the Dutch audit oversight body, the Netherlands Authority for the Financial Markets (AFM), since they are for the most part not publicly disclosed. I differentiate the descriptive statistics by type of audit firm (Big 8 versus nonBig 8), earlier versus later years of public oversight, whether or not the audit firm faced stakeholder dissatisfaction, experienced increased regulatory attention or exited the audit market. In multivariate analyses, I examine the association between these audit firm governance characteristics and the three output measures in order to assess their value in explaining audit quality at the firm level (Martin 2013).

In univariate tests, I find that many audit firm governance characteristics are significantly different for Big 8 and non-Big 8 audit firms, for the earlier years of public oversight (i.e., 2009-2011) versus later years (i.e., 2012-2014), and whether or not audit firms faced stakeholder dissatisfaction, experienced increased regulatory attention, or exited the audit market. Multivariate analyses provide support that several audit firm governance characteristics are associated with distinct firm-level output measures of audit quality, albeit to a different extent. Specifically, I document stakeholder dissatisfaction to be associated with the audit firm expecting organizational change or discontinuity and a higher proportion of audit clients for which audit fees are smaller than fees for other services. Further, I document regulatory attention to be associated with a lower proportion of audit-qualified directors, a higher proportion of audit clients for which audit fees are smaller than fees for other services, no SRA membership ${ }^{4}$, increased stakeholder dissatisfaction in the previous year, more registered signals, and more and larger audit engagements. Finally, I document audit market exits to be associated with the audit firm expecting organizational change or discontinuity, more stakeholder dissatisfaction, increased regulatory attention in the previous year, more registered signals, a lower likelihood of having appointed a compliance officer, and fewer and smaller audit engagements. Interestingly, additional tests provide evidence that the

3 I.e., all audit firms that have a license to perform statutory audits in the Netherlands and actually perform such audits.

4 SRA is the association for cooperating registered accountants and accounting administration consultants, which performs regular quality reviews for its members. 
informational value of the audit firm governance characteristics has increased over time. Collectively, these findings contribute to the growing literature on audit firm governance characteristics and audit quality indicators.

The remainder of this study proceeds as follows. The next section reviews prior literature on audit firm governance and audit quality indicators, and describes the development of the general research hypothesis. The third section describes the data collection and research design. The fourth section describes the hypothesis development. The empirical findings are reported in the fifth section. Finally, the last section provides the conclusion, limitations, and suggestions for further research.

\subsection{Background}

\subsubsection{Audit Firm Governance Definition and Regulation}

Audit firm governance consists of mechanisms and procedures such as authority structures, rules, policies, standard operating procedures, and reward and incentive systems (Hopwood 1976). The IOSCO report (2009) considers audit firm governance to include policies and structures that comprise how the entity is organized as well as the systems, policies, and procedures in place to achieve various goals, including audit quality. The governance, including the organizational structure and the system of quality control, of audit firms is perceived to have a significant influence on audit quality and an audit firm's ability to continuously provide audit services to the market. Therefore, it supports audit firms in their objectives of performing high quality work that gives confidence to shareholders, according to the U.K. Audit Firm Governance Code (ICAEW/ FRC 2010, 2).

Since audit firm governance is expected to have a significant influence on the audit quality delivered by the firm, regulations have been introduced to enhance audit firm governance (e.g., The Sarbanes-Oxley Act of 2002 (U.S. House of Representatives 2002), Directive 2006/43/EC on Statutory Audits of Annual and Consolidated Accounts (European Union 2006), and the Audit Firm Governance Code in the U.K. (ICAEW/FRC 2010)). In the Netherlands, these requirements have been implemented in the Audit Firms Supervision Act (AFS Act 2006) which came into force in October 2006 and concerns the Dutch implementation of the aforementioned E.U. Directive (European Union 2006). These requirements concern the audit firms' organizational characteristics and their systems of quality control. The organizational aspects apply for instance to the good reputation of the audit firm's leadership, ownership and voting rights in the audit firm, appointment of independent non-executives or installment of an independent 
supervisory body ${ }^{5}$, and generally the controlled and sound business operations that should prevent the involvement of the audit firm or its employees in any integrity issue which could be detrimental to the confidence in the audit firm or in the financial markets. Furthermore, the AFS Act requires audit firms to comply with the regulations and standards set by the professional body. Quality control requirements applicable in the Netherlands are primarily stipulated by the auditing standards set by the IAASB, e.g., ISA 220 and ISQC 1 (IAASB 2009a, 2009c) and implemented by the Dutch professional body for auditors. Audit firms must have and maintain a system of quality control that includes policies and procedures that address each of the following elements: (a) leadership responsibilities for quality within the firm; (b) relevant ethical requirements; (c) acceptance and continuance of client relationships and specific engagements; (d) human resources; (e) engagement performance (including direction, supervision and performance, reviews, consultation, and engagement quality control review (EQCR)); and (f) monitoring (IAASB 2009c, paragraph 16). The Dutch audit oversight body supervises the compliance with all applicable legislation, regulation and standards by audit firms performing statutory audits.

\subsubsection{Prior Literature}

There is ample research on the positive effects of strong corporate governance on companies. For instance, better-governed companies are found to have a lower incidence of (accruals-based) earnings management, fraud and fraudulent reporting (e.g., Klein 2002; Beasley et al. 2000; Niu 2006), to have higher operating performance (e.g., Klein 1998; Klapper and Love 2004; Vander Bauwhede 2009), and to be relatively more profitable, more valuable, and pay out more cash to their shareholders (Brown and Caylor 2004). ${ }^{6}$ However, Jenkins et al. (2008) argue that while there is a significant body of literature on governance structures within corporations, much of the findings reported in that literature are not applicable to audit firms because of their distinct operating and ownership characteristics. For instance, while corporate governance typically recognizes stockholders as the primary stakeholder, the auditor's responsibility to act in the public interest suggests that audit firm governance should recognize a diverse set of stakeholders (e.g., investors, regulators, clients, and employees) (Jenkins et al. 2008). Further, audit firms are generally regarded as professional services firms (Morris and Empson 1998) or knowledge-intensive firms (Ditillo 2004) since they provide intangible solutions to

\footnotetext{
In 2014, the Future Accountancy Profession Working Group, consisting of a number of young audit partners of various large and smaller audit firms, drafted a sector-wide report with measures to improve the quality and independence of the audit in the Netherlands (Future Accountancy Profession Working Group 2014). The Dutch audit firms with PIE audit clients have committed themselves to implementing these measures. One of these measures involves the installment of independent supervisory bodies at audit firms with PIE clients. The Dutch legislator has embraced this measure and is expected to implement this requirement in the AFS Act on 1 July 2017.

6 It should be noted that it is challenging in these types of studies to control for endogeneity.
} 
customer problems by using mainly the knowledge of their individuals. For this reason, Covaleski et al. (1998) suggest that the traditional view of control or governance within organizations (i.e., bureaucratic versus professional controls) fails to recognize that for audit firms elements of each form of control may be present. Greenwood et al. (1990) point out that in corporate governance there is separation between ownership, management, and operational employees. However, in audit firms, often organized as partnerships, ownership, management, and operations are combined.

Research on audit firm governance, and audit firm characteristics in general, is limited. Studies on audit firm characteristics appear to have started with a focus on management or cost control (e.g., McNair 1991; Abernethy and Stoelwinder 1995; Otley and Pierce 1996; Ditillo 2004; Pierce and Sweeney 2005; Sweeney and Pierce 2005, 2006) or with a focus on one specific audit firm aspect, such as size (Big 4/ non-Big 4 dichotomy) or industry specialization (Francis 2011). A number of prior studies have examined a broader set of audit firm characteristics and their association with various audit quality measures. For instance, Casterella et al. (2010) examined the association between certain audit firm characteristics and audit firm litigation risk. They find that larger firms, firms experiencing rapid growth, firms that sue their clients, firms with a history of (regulatory) problems, and firms that choose smaller deductibles all face greater litigation risk. Other studies relate various audit firm characteristics to PCAOB-identified audit deficiencies, and find these deficiencies positively associated with the number of issuer clients and audit firm growth and negatively associated with audit firm size, the number of branch offices, the human capital leverage and the organization structure as Limited Liability Partnership firms (Hermanson et al. 2007; Kang et al. 2014). DeFond and Lennox (2011) studied the characteristics of audit firms exiting the audit market following SOX and find that the over six hundred exiting firms are of lower quality, where quality is measured by: (1) avoidance of AICPA peer reviews and failure to comply with PCAOB rules, and (2) severity of the peer review and inspection reports. Christensen et al. (2015a) add to this study by examining characteristics of audit firms merging with other audit firms following SOX and find that small audit firms with a higher inspection burden (i.e., that were inspected by the PCAOB and/or had a higher number of engagements inspected by the PCAOB) had a higher likelihood to be acquired, while larger firms (with more partners and more clients) were more likely to be on the acquiring side of the merger. Lee and Bae (2012) operationalize and calculate eight input-based and two output-based audit firm quality indicators ${ }^{7}$ and find that these generally relate positively to audit hours, audit fees, and negatively to discretionary accruals, and prior year error corrections at the engagement-level. However, when examining audit firm governance disclosures in

\footnotetext{
I.e., professional staff-to-partner ratio, partner-to-public company client ratio, professional staff-to-public company client ratio, professional chargeable hours managed per audit partner, chargeable hours per audit professional staff, annual staff retention, percentage of an audit firm's revenues spent on training, and average years of professionals' experience (input-based indicators), and assurance revenue ratio and average profits per partner (output-based) (Lee and Bae 2012).
} 
transparency reports, Deumes et al. (2012) do not find an association with actual audit quality measured by abnormal working capital accruals. They conclude that current transparency report disclosures do not appear to reveal underlying audit firm quality. Based on a summary of disclosures made in the 2013 transparency reports by Australian audit firms, Fu et al. (2015) find diversity in the disclosures, especially in the areas which may impact audit quality (i.e., the audit firms' internal quality control systems, independence practices, continuing education policies and partners' remuneration structures).

\subsection{Development of Hypothesis}

As Knechel et al.(2013) point out, users, auditors, regulators, and society—all stakeholders in the financial reporting process-may have very different views as to what constitutes audit quality. This will influence the type of indicators one might use to assess audit quality. Since the purpose of audit quality indicators is to improve transparency of audit firms and their audit processes, and thereby providing incentives for firms (e.g., through increased competition) to increase audit quality (Bedard et al. 2010; Martin 2013; PCAOB 2015), the primary focus of the audit quality indicators appears to be at the audit firmlevel (as opposed to the audit engagement-level). In fact, a distinguishing feature of auditor characteristic measures when compared to the other audit quality measures is that they are not engagement specific (DeFond and Zhang 2014). Therefore, I infer audit quality from three direct firm-level output measures: (a) stakeholder dissatisfaction; (b) regulatory attention; and (c) audit market exit. I examine the association of various audit firm governance characteristics with these three output measures (which are further operationalized in the next section). Based on the assumptions and expectations underlying the audit firm governance requirements, I posit the following research hypotheses:

H1: Audit firms with stronger governance mechanisms in place are less likely to be confronted with stakeholder dissatisfaction.

H2: Audit firms with stronger governance mechanisms in place are less likely to trigger regulatory attention.

H3: Audit firms with stronger governance mechanisms in place are less likely to exit the audit market.

\subsection{Research Design}

\subsubsection{Sample}

I obtained the data for this study from the proprietary files of the Dutch oversight body, the AFM. The AFM is responsible for public oversight of audit firms performing statutory 
audits in the Netherlands. It grants licenses to audit firms that wish to perform statutory audits and revokes licenses if audit firms no longer perform statutory audits and request the AFM to do so or if an audit firm is severely non-compliant with the applicable requirements. The AFM keeps a public register of licensed audit firms, including detailed information about for instance the audit firms' management, auditors, and legal form. Audit firms have been required to apply for a license to perform statutory audits since October 2006. In the first two years, i.e., until 2008, a transitional regime was applicable in which the AFM assessed the license applications of all audit firms already active in the audit market in 2006. In 2009, the AFM started its 'regular' inspections of licensed audit firms. As part of its risk-based supervision, the AFM requests licensed audit firms to complete a yearly monitoring questionnaire including, amongst other topics, questions regarding the audit firms' governance and client portfolios. Furthermore, the AFM maintains records of its internally registered signals about licensed audit firms, performs inspections and investigations, and imposes sanctions.

From this data, I created a panel dataset for the period 2009 to 2014 consisting of audit firm observations for each year in which the audit firm was licensed to perform statutory audits. Observations of audit firms ceasing to exist due to a merger with another audit firm, death or retirement of management (i.e., mostly the sole proprietor) were excluded. Observations of audit firms not performing any statutory audits were also excluded. ${ }^{8}$ After excluding audit firm-year observations with insufficient data to perform

Table 1

\section{Sample Composition}

\begin{tabular}{|c|c|c|c|c|c|c|}
\hline \multirow[b]{2}{*}{ Year } & \multicolumn{3}{|c|}{ Active licenses } & \multicolumn{3}{|c|}{ Observations } \\
\hline & Total & New & Revoked & Deleted & $\begin{array}{r}\text { Missing } \\
\text { data }\end{array}$ & Total \\
\hline 2009 & 501 & 18 & 22 & 73 & 99 & 329 \\
\hline 2010 & 501 & 22 & 29 & 108 & 16 & 377 \\
\hline 2011 & 490 & 18 & 16 & 92 & 9 & 389 \\
\hline 2012 & 487 & 13 & 30 & 92 & 6 & 389 \\
\hline 2013 & 467 & 10 & 27 & 89 & 4 & 374 \\
\hline 2014 & 445 & 5 & 31 & 66 & 2 & 377 \\
\hline Total & & 86 & 155 & 515 & 141 & 2,235 \\
\hline
\end{tabular}

This table reports the number of active licensed audit firms (total, newly granted licenses, and revoked licenses), observations deleted because of mergers, death, retirement, or because the audit firm performs no statutory audits, audit firms with missing data, and the number of observations in the sample for each year (2009-2014), respectively.

8 Audit firms not performing any statutory audits are excluded for two reasons. First, these audit firms may have had other incentives to apply for a license, since they legally do not require one. Second, many audit firm governance variables are by default equal to 0 if the audit firm performs no statutory audits. 
multivariate tests, the final sample consists of 2,235 observations. The sample composition for each of the years 2009-2014 is reported in Table $1 .{ }^{9}$ This table shows that the number of actively licensed audit firms steadily declined by 11 percent in the 20092014 period (from 501 to 445 ).

\subsubsection{Empirical Model}

I examine the relationship between audit firm governance characteristics, i.e., audit firms' organizational and quality control characteristics, and audit firm quality, using variations of the following regression model:

$$
\begin{aligned}
& A F Q_{t}=\beta_{0}+\beta_{1} \text { EXDIRECTOR_AUDIT }{ }_{t}+\beta_{2} S U P E R V I S O R Y B O D Y \\
& +\beta_{3} \text { IIMLIAB }_{t}+\beta_{4} \text { ORGDISCONT }_{t}+\beta_{5} \text { COMPLOFF }_{t}+\beta_{6} \text { EQCR }_{t} \\
& +\beta_{7} \text { LOWAFCLIENTS }+\beta_{s} \text { LNTOTALFEE_AUDITOR }{ }_{t}+\beta_{9} \text { AUDITORS_RA }{ }_{t} \\
& +\beta_{10} \text { QUESTIONS }_{t}+\beta_{11} \text { SRA }_{t}+\beta_{12} \text { AUDITSCHANGE }_{t}+\beta_{13} \text { LNAUDITS }_{t} \\
& +\beta_{14} \text { SIGNALSCOUNT }_{t}+\beta_{15} \text { LNAV_AUDITFEE }_{t}+\beta_{16} \text { SPECIALIST }_{t} \\
& + \text { Year Fixed Effects }+\varepsilon
\end{aligned}
$$

where $A F Q$ reflects audit firm quality operationalized by three distinct audit firm-level output measures, as described below and summarized in Table 2.

\section{Dependent Variables: Audit Firm Quality Measures}

In Model (1), AFQ is operationalized by (a) stakeholder dissatisfaction (DISSAT); (b) regulatory attention (REGATT); and (c) audit market exit (EXIT), which are all indicative of lower audit firm quality. ${ }^{10}$ By inferring audit quality from these audit firm-level measures, the unit of analysis is similar on both sides of the equation: the dependent variables (i.e., DISSAT, REGATT, and EXIT) and the explanatory variables are quality indicators at the audit firm level. Further, these measures enable an analysis of all active audit firms in the Dutch statutory audit market, including both large and small audit firms. Many audit quality proxies are measures on the audit engagement level (e.g., discretionary accruals, going-concern opinions, restatements, audit hours, audit fees), which are practically only measurable for large audit firms, i.e., audit firms with a substantive number of audit clients for which sufficient data are available (e.g., financials statements, stock listings, trading information, auditor reports). This means that these audit quality measures are not applicable to the small(est) audit firms.

Table 1 shows that the number of observations excluded due to missing data is relatively high in 2009. Additional tests (untabulated) show that excluding all observations for the year 2009 does not influence the main findings.

10 Since DISSAT and REGATT are both count variables with limited range and a large proportion of zero-observations, I use zero-inflated negative binomial regressions for models with these measures as the dependent variables. As EXIT is a binary variable, I use a probit regression when this measure is the dependent variable. 
DISSAT indicates the amount of stakeholder dissatisfaction and is measured as the total number of complaints and claims filed directly to the audit firm, complaints filed with the disciplinary court for auditors, and other legal proceedings. Since these events are directly related to the size of the audit firm, the individual components are scaled by either the total number of audit engagements or auditors of the audit firm (see Table 2 for more details). This measure is expected to be a broad approximation of litigation risk.

$\boldsymbol{R E G A T T}$ is the measure of regulatory attention the audit firm receives, i.e., the total number of inspections performed and sanctions imposed by the public oversight body to the audit firm. ${ }^{11}$ Increased attention from the public oversight body may impose costs on audit firms (particularly small firms), which may incentivize them to exit the audit market (DeFond and Lennox 2011). Further, regulatory indicators, such as the number of identified deficiencies, are found to be viewed by investors as important indicators of overall audit firm quality (Christensen et al. 2015b).

$\boldsymbol{E X I T}$ is an indicator variable equal to 1 if the audit firm exits the statutory audit market by having its license revoked, and otherwise 0 . Audit firms may for instance leave the statutory audit market because they deliberately choose to resign from all their statutory audit engagements, their clients are no longer required to have their accounts audited, they are no longer able or willing (e.g., due to costs) to comply with the quality requirements and to be subject to public oversight. Audit firms leaving the statutory audit market because their sole proprietor died or retired, and audit firms that had their license revoked because they merged with or were acquired by another audit firm are eliminated from the sample. A few prior studies have examined audit firms exiting the markets for auditing issuers (Read et al. 2004; DeFond and Lennox 2011) and U.S. brokerdealers (Bedard et al. 2015). These studies focus on exits in the period right before audit firms were required to register with the PCAOB. The audit market exits included in the current study concern audit firms that already entered the market and obtained the required license from the public oversight body, but later had that license revoked and left the statutory audit market. The characteristics of audit firms deciding not to enter a market may be different from the characteristics of audit firms deciding to exit that market after they had already entered. ${ }^{12}$

11 An inspection consists of an assessment by the public oversight body of the audit firm's compliance with the applicable legislation and regulations. This assessment includes the review of a risk-based selection of audit files. The number of audit files reviewed and the duration and extent of the inspection is dependent on the size of the audit firm (i.e., one inspection at a large audit firm may include more audit files and last longer and one inspection at a small audit firm may include fewer audit files and last shorter). Therefore, scaling of the number of inspections is deemed redundant, since it already takes into account audit firm size.

12 The Dutch public oversight body has not yet revoked any licenses as part of its sanctioning powers. Rather, all audit market exits were initiated by the audit firms. 


\section{Test Variables: Audit Firm Organizational Characteristics}

EXDIRECTOR_AUDIT measures the proportion of the audit firm's executive directors managing the audit firm having an audit qualification. Article 3(4)(b) of the Statutory Audit Directive (European Union 2006) and Article 16 of the Dutch AFS Act state that a majority of the members of the administrative or management body of the audit firm (i.e., its executive directors) must be audit firms which are approved in any Member State or natural persons who satisfy at least the conditions imposed on individual auditors (i.e., hold an audit qualification). Since the management of a large professional service organization, such as an audit firm, involves specific knowledge (Van Lent 1999), I expect audit firms with more competent boards, i.e. with a higher proportion of qualified auditors on the board of directors, to be indicative of higher audit firm quality.

SUPERVISORYBODY is an indicator variable equal to 1 if the audit firm has a supervisory body of some sort (e.g., a board or committee with either formal monitoring powers or an informal advisory role), and otherwise 0. Jenkins et al. (2008) describe the PCAOB's consideration of requiring audit firms to establish independent monitoring boards as part of their formal governance mechanisms. In the Netherlands, supervisory boards are expected to be legally required as from 2017. Audit firms have already experimented with various types of supervisory or advisory boards in their governance structures. I expect having a supervisory board in place increases the quality of audit firm's governance, and to be indicative of higher audit firm quality.

LIMLIAB is an indicator variable equal to 1 if the audit firm is a legal entity with limited liability (as opposed to some sort of partnership with unlimited liability), and otherwise 0. In the Netherlands, audit firms are free to choose their preferred legal form. Kang et al. (2014) argue that the audit firm's organizational structure (legal form) is impacted by threemain factors: need for independence from clients, need for competence, and litigation risk. Both Van Lent (1999) and Greenwood and Empson (2003) argue that even though audit firms may adopt the legal form of corporation, they will still be likely to maintain the organizational characteristics of partnerships, since these will be efficient in the audit market suited to the management of knowledge workers. While Lennox and Li (2012) find that audit fees and market shares of LLP audit firms do not change significantly subsequent to LLP adoption, they do find these firms to extend their services to riskier types of companies. Firth et al. (2012) find empirical evidence that the organizational form of an audit firm affects its reporting conservatism (i.e., auditors in partnerships are more likely to issue modified audit reports than auditors in limited liability firms), due to the threat of liability. If audit firms with limited liability have riskier clients and lower reporting conservatism, I consider the audit firm's choice for a legal form with limited liability a sign of weaker audit firm governance and expect it to be indicative of lower audit firm quality.

ORGDISCONT is an indicator variable equal to 1 if the audit firm has indicated in the AFM's yearly monitoring questionnaire to expect any organizational change or discontinuity in the following year (e.g., merger, acquisition, reorganization, change in 
voting rights, participation in or resignation from a network), and otherwise 0 . I expect organizational change or discontinuity to be associated with lower audit firm quality.

\section{Test Variables: Audit Firm Quality Control Characteristics}

Audit firm quality control refers to the audit firm's assessment and control of risk that auditing standards, professional values or the public interest might be violated. Prior studies suggest that audit firms can make a difference in their incidence and severity of 'quality threatening behavior' by careful attention to policies and procedures for assessing, monitoring, and controlling risk of violation of professional standards (Bedard et al. 2008). Stronger quality control is therefore expected to be associated with higher audit firm quality. The following variables are operationalized as measures for audit firm quality control.

COMPLOFF is an indicator variable equal to 1 if the audit firm has appointed a specific person as compliance officer, i.e., an officer responsible for internal oversight of compliance with applicable quality requirements by the audit firm and its employees. Dutch law requires audit firms with a license to audit PIEs to have a compliance officer. For the audit firms only auditing non-PIEs, having a compliance officer is not legally required. Having appointed a compliance officer is arguably a sign of stronger audit firm governance, which is expected to be associated with higher audit firm quality.

EQCR measures the proportion of an audit firm's statutory audits of non-PIEs for which an engagement quality control review ${ }^{13}$ (EQCR) was performed. In line with the requirements of ISQC 1 (IAASB 2009c), Dutch law requires audit firms to have EQCRs performed for all PIE audits (i.e., audits of listed companies, banks and insurers). For non-PIEs audits, audit firms are required to set criteria to evaluate for which non-PIE audits an EQCR should be performed. EQCRs involve a second look at significant audit decisions by a partner with appropriate technical expertise and without direct involvement in the conduct of the engagement (Johnstone et al. 2001), making them more like a peer review than a supervisor-subordinate review (Epps and Messier 2007b). Reviewers describe the EQCR as a professional, collegial, non-adversarial process, primarily focused on the objective of resolving difficult and complex client accounting issues (Emby and Favere-Marchesi 2010). EQCRs have the advantage of a mid-engagement assessment which improves quality as the audit is being conducted as opposed to identifying issues after they occur (Martin 2013). Prior research indicates that an EQCR may reduce audit risk and increase audit quality through a variety of means. EQCRs reduce reporting bias (Tucker and Matsumura 1997), cause engagement partners to report with greater independence and to sample more (Matsumura and Tucker 1995), and reduce objectivity impairment resulting from prior involvement with a client (Tan 1995). Luehlfing et al. (1995) examine the relationship between various risk factors and the extent of actual EQCRs performed for clients. They find significant differences across

13 In prior studies also referred to as concurrent or second partner reviews. 
audit firms with client industry being the only risk factor that impacted the extent of EQCRs. However, Epps and Messier (2007a) find a moderate level of consistency across firms when they performed a review of firm guidance for performing EQCRs. Based on these findings, I expect that more EQCRs (i.e., a higher proportion of non-PIEs for which an EQCR was performed) is indicative of stronger audit firm governance and to be associated with higher audit firm quality.

LOWAFCLIENTS is an indicator of the audit firm's independence. It measures the proportion of the audit firm's audit clients for which the fees for performing the statutory audit are lower than the fees for other services. While prior research indicates that the provision of non-audit services has rarely been associated with impaired audit quality, and in some cases it is associated with higher audit quality (Church et al. 2015; DeFond and Zhang 2014; Gramling et al. 2010), regulators are generally concerned that non-audit services make auditors financially dependent on their clients and that the consulting nature of many non-audit services puts auditors in managerial roles (DeFond et al. 2002). Therefore, I expect lower values for LOWAFCLIENTS to be indicative of stronger auditor independence and audit firm governance, associated with higher audit firm quality.

LNTOTALFEE_AUDITOR measures the natural logarithm of the total fees charged to audit clients per auditor and is a measure of auditor workload. Buchheit and Buslepp (2014) find that audit firms under a relatively heavy workload produce lower quality audits. Hence, I expect a higher value of LNTOTALFEE_AUDITOR to be indicative of higher workloads and weaker audit firm governance, associated with lower audit firm quality.

AUDITORS_RA measures the proportion of the audit firm's auditors with a RA (i.e., registered accountant) qualification. In the Netherlands, two types of auditors may perform statutory audits: registered accountants (RA), which have completed universitylevel education and are more specialized in performing audits, and accounting administration consultants (AA), which have completed higher vocational education, and are more specialized in providing administrative services to mid-sized and smaller companies. In the statutory audit context of this study, I expect audit firms with a higher proportion of auditors with a RA qualification to have stronger audit firm governance and to be associated with higher audit firm quality.

QUESTIONS is the number of questions asked by the audit firm to the public oversight body, scaled by the number of audits performed by the audit firm. A higher number of questions is expected to be indicative of appropriate consultation taking place on difficult or contentious matters, and therefore to be a signal of stronger audit firm governance, and associated with higher audit firm quality.

$\boldsymbol{S R A}$ is an indicator variable equal to 1 if the audit firm is a member of the association for cooperating registered accountants and accounting administration consultants (i.e., the SRA), and otherwise 0. The SRA is the largest association of audit firms which are mainly active for small and medium enterprises and provides practical and strategic support to its members. To become a SRA member, balloting takes place. 
Furthermore, to ensure a constant and high level of quality of its members, the SRA performs regular quality reviews. Because of this activity, the public oversight body has signed a covenant with the SRA in which it is stipulated that the public oversight body takes into consideration the outcomes of the SRA reviews in its risk analyses for its supervision of audit firms. As a matter of policy, voluntary participation in a quality (peer) review process, such as performed by the SRA, represents a commitment to quality by the audit firm (Johnstone et al. 2001). In their examination of audit firms exiting the audit market, DeFond and Lennox (2011) interpret the exiting audit firms' avoidance of AICPA peer reviews as lower quality. I expect an audit firm's membership of the SRA (and hence its participation in the SRAs quality review process) to be indicative of stronger audit firm governance and to be associated with higher audit firm quality.

AUDITSCHANGE approximates the volatility in the audit firm's audit engagement portfolio by dividing the sum of newly acquired and lost audit engagements by the total number of audit engagements performed. Audit firms are required to establish policies and procedures for the acceptance and continuance of audit engagements, and to notify the public oversight body of all statutory audit engagements that are prematurely terminated (i.e., before the issuance of the auditor's report). A highly volatile engagement portfolio is expected to put strains on the audit firm's quality controls and to be associated with lower audit firm quality.

\section{Control Variables}

Audit firm size and risk, client portfolio characteristics and year dummies are included as control variables in the estimation model.

Academic literature generally concludes that audit quality is higher among larger firms (e.g., Watkins et al. 2004; Francis 2004), because they are likely to be more independent (DeAngelo 1981b) and because risk sharing reduces agency costs (Balachandran and Ramakrishnan 1987). While universal application of standards (e.g., regarding audit firm governance) might result in quality improvement among all audit firms regardless of firm size, small firms are likely to be less able to bear the associated costs (Bedard et al. 2008). In the Netherlands there are eight large audit firms that are all part of a worldwide audit network: Deloitte, EY, KPMG, PwC, Baker Tilly, BDO, Grant Thornton, and Mazars. In this study, these eight audit firms are referred to as the Big 8. Further, the non-Big 8 audit firms can be divided into three size categories: audit firms with more than 25 audit engagements are considered large firms; firms with 6 to 25 audit engagements are considered medium-sized firms; and firms with fewer than 6 audit engagements are considered small firms. In order to control for the differences in audit firm characteristics caused by audit firm size, the natural logarithm of the number of audit performed by the audit firm (LNAUDITS) is included in the estimation model. ${ }^{14}$

Audit firm risk is approximated by the number of signals registered by the public

\footnotetext{
${ }_{14}$ In additional analyses, three indicator variables are included in the estimation model: BIG8, LARGEFIRMS, and MEDFIRMS (with the small audit firms as the reference category).
} 
oversight body regarding the audit firm (SIGNALSCOUNT). Signals are information from public and proprietary sources (e.g., news media, other oversight departments within the AFM, or other authorities) indicating potential non-compliance with applicable legislation and regulation or other risks for the audit firm's reputation, quality or continuity. A higher number of registered signals is expected to be indicative of higher audit firm risk and potentially lower audit firm quality.

Two variables are included to account for client portfolio characteristics. LNAV AUDITFEE approximates the audit firm's average client size by measuring the natural logarithm of the audit firm's average audit fees per audit client. SPECIALIST measures the diversity in the audit firm's client portfolio and is equal to 1 if the audit firm performs over 60 percent of its statutory audits for audit clients in the same industry, and otherwise 0 .

In addition to the variables presented in equation (1), the stakeholder dissatisfaction measure (DISSAT) is added to the equation as a test variable when REGATT and EXIT are the dependent variables, to measure whether stakeholder dissatisfaction is associated with increased regulatory attention and more frequent audit market exits. The previous year's value of the regulatory attention measure (REGATT_LAG) is added to the equation as a test variable when EXIT is the dependent variable, to measure whether regulatory attention is associated with an increase in audit market exits in the subsequent year.

Table 2 summarizes all variable definitions.

\subsection{Results}

\subsubsection{Descriptive Statistics and Univariate Results}

Descriptive statistics are presented in Table 3. The columns present descriptive statistics for the full sample of 2,235 audit firm-year observations and for the various subsamples of observations (Big 8 and non-Big 8, 2009-2011 and 2012-2014, stakeholder dissatisfaction and no stakeholder dissatisfaction, regulatory attention and no regulatory attention, and exit and non-exit, respectively). The last column reports the t-or z-statistics for the difference between the two subsamples. ${ }^{15}$

The organizational characteristics in the first columns of Panel A show that a large majority of the audit firms' executive directors are qualified auditors ( 87.5 percent), which is well above the legal minimum of more than 50 percent. Only a few audit firms have a supervisory body installed (6 percent) and most audit firms are organized as a legal entity with limited liability (71.3 percent). Almost 16 percent of the audit firms indicated to expect some organizational change or discontinuity within the following year (e.g.,

15 I perform two-sample t-tests on characteristics measured by continuous variables, and twosample tests of proportion on characteristics measured by binary (indicator) variables or variables that represent a proportion (between 0 and 1 ). 
Table 2

\section{Variable Definitions}

\begin{tabular}{|c|c|}
\hline Variable & Definition \\
\hline \multicolumn{2}{|l|}{ Organizational Characteristics } \\
\hline EXDIRECTOR_AUDIT & $\begin{array}{l}\text { Proportion of the audit firm's executive directors with an } \\
\text { audit qualification (i.e., number of executive directors } \\
\text { with an audit qualification divided by the total number of } \\
\text { executive directors). }\end{array}$ \\
\hline SUPERVISORYBODY & $\begin{array}{l}\text { An indicator variable equal to } 1 \text { if the audit firm has a } \\
\text { supervisory body, and otherwise } 0 \text {. }\end{array}$ \\
\hline LIMLIAB & $\begin{array}{l}\text { An indicator variable equal to } 1 \text { if the audit firm is a legal } \\
\text { entity with limited liability, and otherwise } 0 .\end{array}$ \\
\hline ORGDISCONT & $\begin{array}{l}\text { An indicator variable equal to } 1 \text { if the audit firm has indicated } \\
\text { to expect any organizational change or discontinuity in the } \\
\text { following year (e.g., merger, acquisition, reorganization, } \\
\text { change in voting rights, participation in network), and } \\
\text { otherwise } 0 \text {. }\end{array}$ \\
\hline $\begin{array}{l}\text { Audit Firm Quality Control } \\
\text { COMPLOFF }\end{array}$ & $\begin{array}{l}\text { An indicator variable equal to } 1 \text { if the audit firm has } \\
\text { appointed a compliance officer, and otherwise } 0 .\end{array}$ \\
\hline EQCR & $\begin{array}{l}\text { Proportion of the audit firm's non-PIE statutory audits for } \\
\text { which an engagement quality control review (EQCR) was } \\
\text { performed. }\end{array}$ \\
\hline LOWAFCLIENTS & $\begin{array}{l}\text { Proportion of the audit firm's audit clients for which the } \\
\text { fees for performing the statutory audit are lower than the } \\
\text { fees for other services provided to those audit clients. }\end{array}$ \\
\hline LNTOTALFEE_AUDITOR & $\begin{array}{l}\text { Natural logarithm of an audit firms' average total fees (in } \\
\text { thousand euros) charged to audit clients per auditor. }\end{array}$ \\
\hline AUDITORS_RA & $\begin{array}{l}\text { Proportion of auditors with RA qualification (i.e., registered } \\
\text { accountant). }\end{array}$ \\
\hline QUESTIONS & $\begin{array}{l}\text { Number of questions asked by the audit firm to the public } \\
\text { oversight body (scaled by the number audits performed). }\end{array}$ \\
\hline$S R A$ & $\begin{array}{l}\text { An indicator variable equal to } 1 \text { if the audit firm is a member } \\
\text { of the association for cooperating registered accountants } \\
\text { and accounting administration consultants (SRA), and } \\
\text { otherwise } 0 \text {. }\end{array}$ \\
\hline Stakeholder Dissatisfaction & $\begin{array}{l}\text { An audit firms' audit client portfolio volatility (i.e., the } \\
\text { sum of newly acquired audit engagements and lost audit } \\
\text { engagements divided by the total number of audits } \\
\text { performed). }\end{array}$ \\
\hline COMPLAINTS & $\begin{array}{l}\text { Number of complaints and claims received by the audit } \\
\text { firm concerning the performance of statutory audits (scaled } \\
\text { by the number of audits performed). }\end{array}$ \\
\hline DISCCOMPL & $\begin{array}{l}\text { Number of complaints filed with the disciplinary court } \\
\text { against one of the audit firm's auditors (scaled by the } \\
\text { number of auditors). }\end{array}$ \\
\hline PROCEEDINGS & $\begin{array}{l}\text { Number of legal proceedings against the audit firm } \\
\text { (including criminal, civil, and administrative proceedings) } \\
\text { (scaled by the number of audits performed). }\end{array}$ \\
\hline DISSAT & $\begin{array}{l}\text { Stakeholder dissatisfaction, i.e., the sum of COMPLAINTS, } \\
\text { DISCCOMPL, and PROCEEDINGS. }\end{array}$ \\
\hline
\end{tabular}




\begin{tabular}{|c|c|}
\hline DISSAT_DUM & $\begin{array}{l}\text { An indicator variable equal to } 1 \text { if the sum of COMPLAINTS, } \\
\text { DISCCOMPL, and PROCEEDINGS is larger than } 0 \text {, and } \\
\text { otherwise } 0 \text {. }\end{array}$ \\
\hline \multicolumn{2}{|l|}{ Regulatory Attention } \\
\hline INSPECTION_COUNT & $\begin{array}{l}\text { Number of inspections performed by the public oversight } \\
\text { body at the audit firm. }\end{array}$ \\
\hline SANCTION_COUNT & $\begin{array}{l}\text { Number of sanctions imposed by the public oversight body } \\
\text { on the audit firm. }\end{array}$ \\
\hline REGATT & $\begin{array}{l}\text { Number of regulatory events related to the audit firm, i.e., } \\
\text { the sum of INSPECTION_COUNT and SANCTION_COUNT. }\end{array}$ \\
\hline REGATT_DUM & $\begin{array}{l}\text { An indicator variable equal to } 1 \text { if the sum of INSPECTION } \\
\text { COUNT and SANCTION_COUNT is larger than } 0 \text {, and } \\
\text { otherwise } 0 \text {. }\end{array}$ \\
\hline REGATT_LAG & $\begin{array}{l}\text { Lagged value of } R E G A T T \text {, i.e., previous year's number of } \\
\text { regulatory events related to the audit firm. }\end{array}$ \\
\hline \multicolumn{2}{|l|}{ Audit Market Exit } \\
\hline EXIT & $\begin{array}{l}\text { An indicator variable equal to } 1 \text { if the audit firm exits the } \\
\text { statutory audit market, and otherwise } 0 \text {. }\end{array}$ \\
\hline \multicolumn{2}{|r|}{ 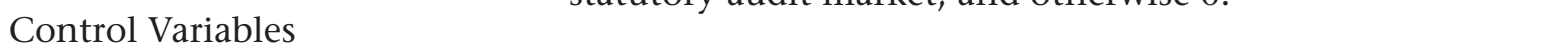 } \\
\hline LNAUDITS & $\begin{array}{l}\text { Natural logarithm of an audit firms' total number of } \\
\text { statutory audits performed. }\end{array}$ \\
\hline$B I G 8$ & $\begin{array}{l}\text { An indicator variable equal to } 1 \text { if the audit firm is a member } \\
\text { firm of one of eight worldwide network organizations } \\
\text { (Deloitte, EY, KPMG, PwC, Baker Tilly, BDO, Grant } \\
\text { Thornton, or Mazars), and otherwise 0. }\end{array}$ \\
\hline LARGEFIRMS & $\begin{array}{l}\text { An indicator variable equal to } 1 \text { if the audit firm is not a Big } \\
8 \text { audit firm and has more than } 25 \text { audit engagements, and } \\
\text { otherwise } 0 \text {. }\end{array}$ \\
\hline MEDFIRMS & $\begin{array}{l}\text { An indicator variable equal to } 1 \text { if the audit firm is not a } \\
\text { Big } 8 \text { audit firm and has } 6 \text { to } 25 \text { audit engagements, and } \\
\text { otherwise } 0 \text {. }\end{array}$ \\
\hline SMALLFIRMS & $\begin{array}{l}\text { An indicator variable equal to } 1 \text { if the audit firm is not a Big } \\
8 \text { audit firm and has fewer than } 6 \text { audit engagements, and } \\
\text { otherwise } 0 \text {. }\end{array}$ \\
\hline SIGNALSCOUNT & $\begin{array}{l}\text { Number of signals registered by the public oversight body } \\
\text { regarding the audit firm (scaled by the number of audits } \\
\text { performed). }\end{array}$ \\
\hline LNAV_AUDITFEE & $\begin{array}{l}\text { Natural logarithm of an audit firms' average audit fees (in } \\
\text { thousand euros) per audit engagement. }\end{array}$ \\
\hline SPECIALIST & $\begin{array}{l}\text { An indicator variable equal to } 1 \text { if the audit firm performs } \\
\text { over } 60 \text { percent of its audits for audit clients in the same } \\
\text { industry, and otherwise } 0 \text {. }\end{array}$ \\
\hline$Y 2009-Y 2014$ & $\begin{array}{l}\text { Indicator variables equal to } 1 \text { if the year is } 2009,2010,2011 \text {, } \\
2012,2013 \text {, or } 2014 \text {, respectively, and otherwise } 0 .\end{array}$ \\
\hline
\end{tabular}


merger, acquisition, reorganization, change in voting rights, or participation in a network). The audit firm quality control variables show that 75.5 percent of the audit firms haveappointed a complianceofficer responsible for internaloversight of compliance with applicable legislation and regulation. On average, almost 46 percent of all statutory audits performed for non-PIE audit clients are subject to an EQCR. For just over 17 percent of audit clients the audit fee is smaller than the fee for other services performed for those clients. The average natural logarithm of the total fees per auditor amounts to 4.295. Of the auditors employed by or associated with the audit firms, 64.2 are registered accountants (i.e., RA, with completed university level education). Relative to the number of audits they perform, audit firms ask few questions to the public oversight body (on average 1.6 questions per 100 audits). A majority (59.4 percent) of the audit firms are members of the SRA. Audit client portfolio volatility, i.e., the sum of newly acquired audit engagements and lost audit engagements divided by the total number of audits performed, is 26.8 percent.

Over a quarter of all audit firms (25.6 percent) are faced with dissatisfied stakeholders (on average 7.6 per 100 audits), i.e., complaints filed with the audit firm, complaints filed with the disciplinary court for auditors, or legal proceedings. Just over 9 percent of the audit firms are experiencing regulatory attention (i.e., inspections and sanctions), with an average of 13.8 inspections and 2.1 sanctions per 100 audit firms. In total, 2.1 percent of the observations involves an audit firm exiting the statutory audit market by having its license revoked.

The control variables show the mean natural logarithm of the number of audits performed by the audit firms, the division of observations in audit firm size categories (i.e., Big 8 and large, medium, and small non-Big 8 audit firms), and the mean natural logarithm of average audit fee per audit client. Further, the control variables show that for each 100 audits, the public oversight body registers 2.4 signals (i.e., information indicating auditfirm risk) and approximately 43 percent of theauditfirms arecharacterized as specialists, since they perform more than 60 percent of their audits for clients in the same industry.

Panel A also reports the descriptive statistics and univariate test results for the subsamples of Big 8 and non-Big 8 audit firms. Big 8 and non-Big 8 audit firms differ significantly on all four organizational characteristics. Big 8 firms have a lower proportion of executive directors with an audit qualification (i.e., they have more non-auditors on their boards of directors), have installed more often a supervisory body, are all organized as legal entities with limited liability, and have indicated more often to expect some sort of organizational change or discontinuity in the following year. Big 8 and non-Big 8 audit firms also differ significantly on almost all quality control characteristics. Big 8 firms have, as legally prescribed, all appointed a specific person as compliance officer, while approximately 74 percent of the non-Big 8 audit firms have a compliance officer. Further, Big 8 firm auditors have higher workloads (i.e., higher average total fees per auditor), a higher proportion of auditors with a university-level education (i.e., RA qualification), and ask fewer questions to the public oversight body (relative to the number of audits 


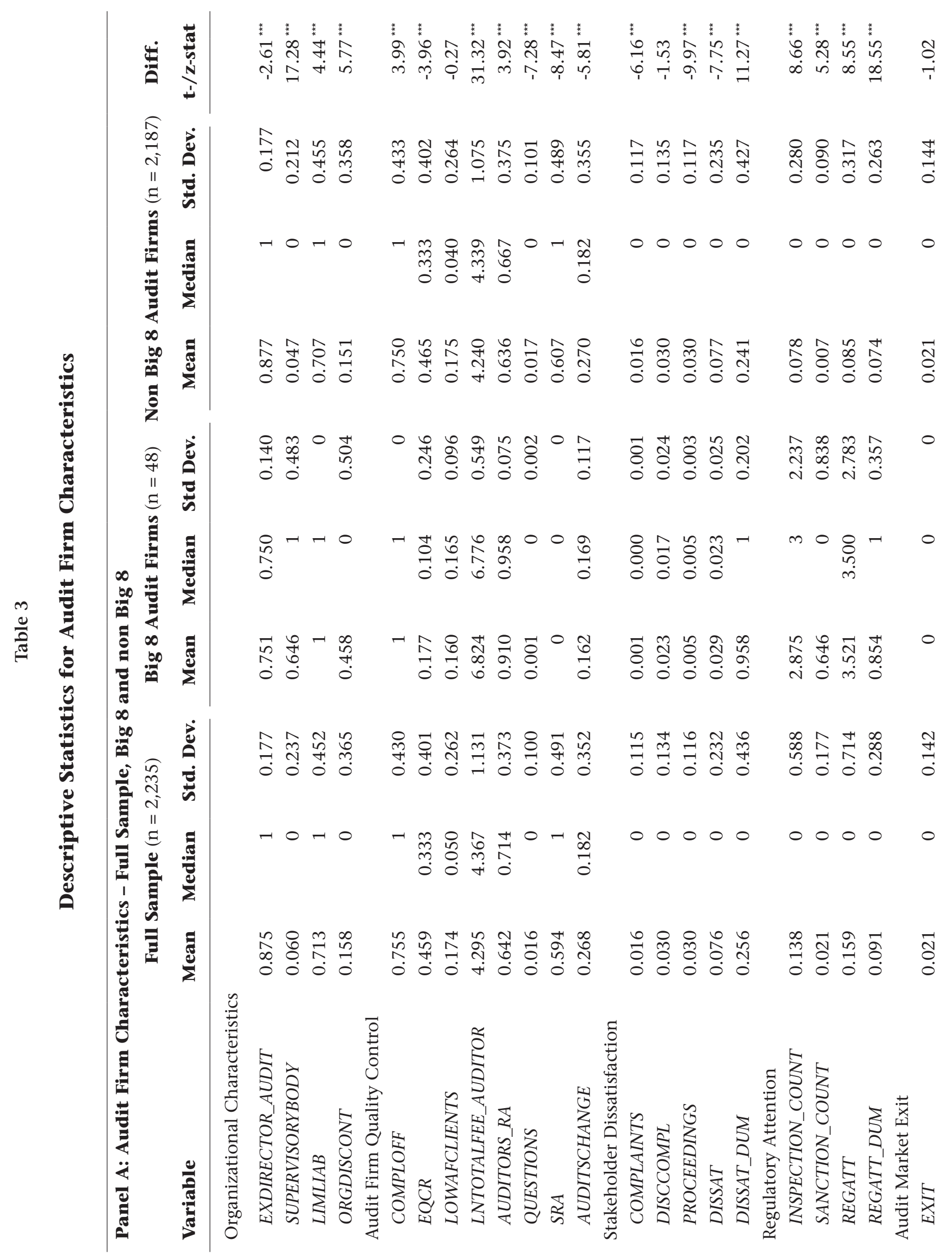




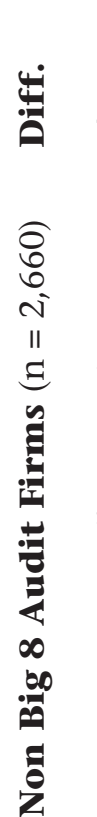

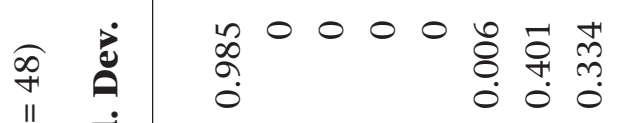

"I

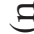

: (1)

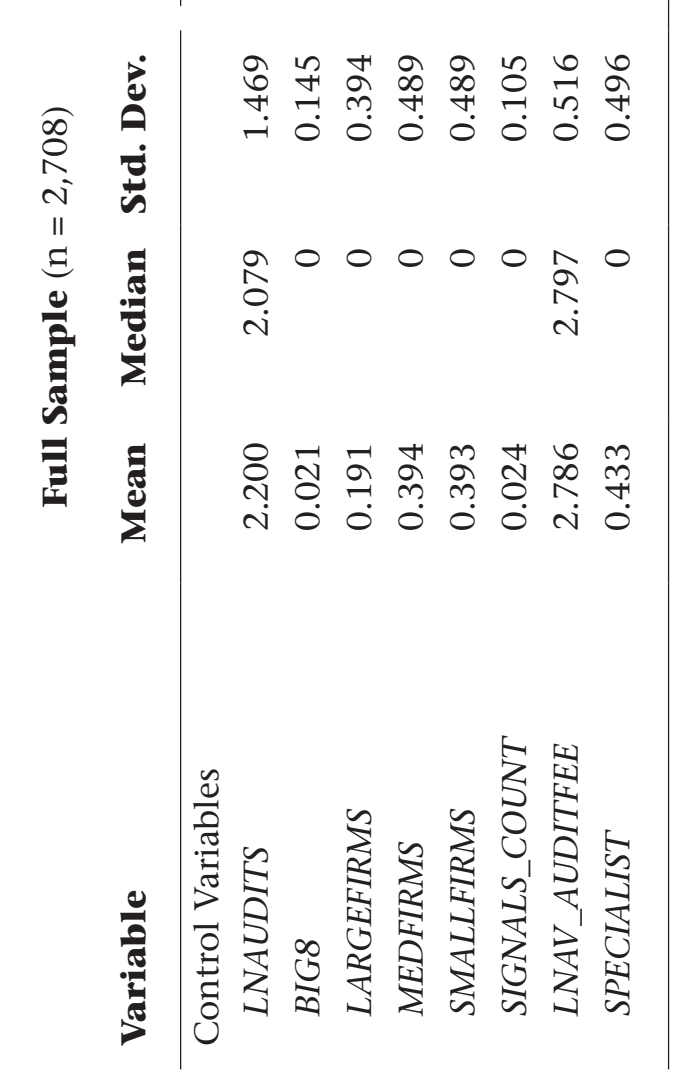




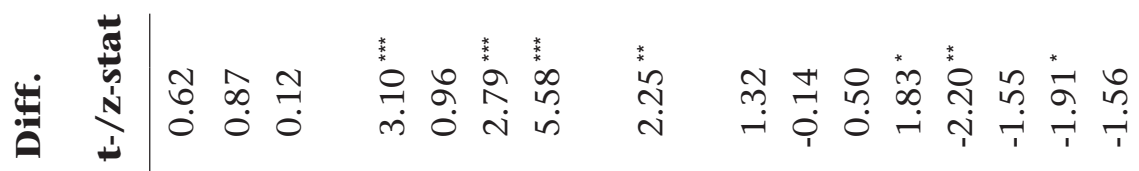

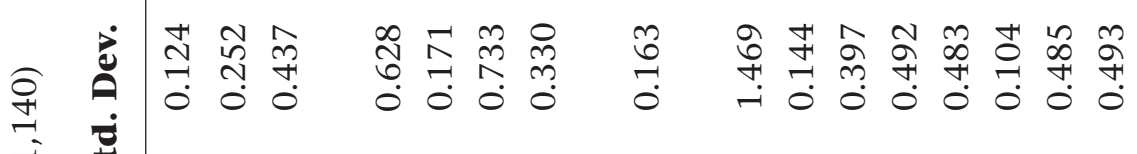
$\stackrel{\text { II }}{=}$

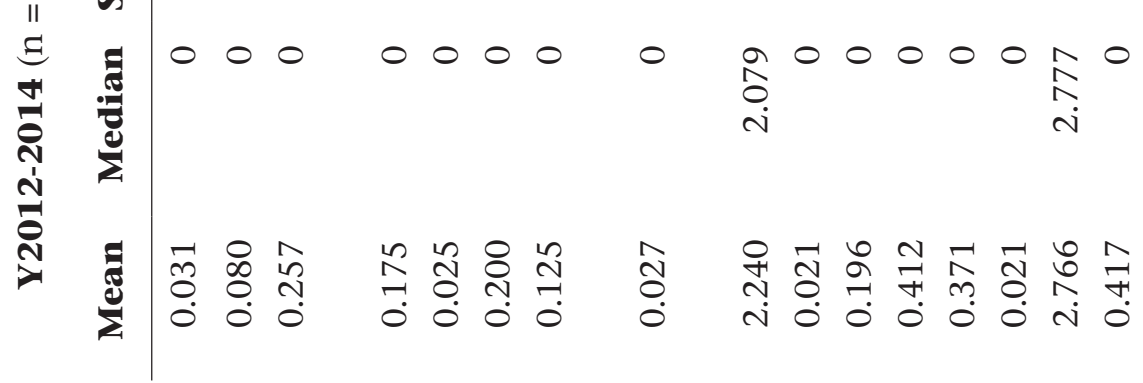

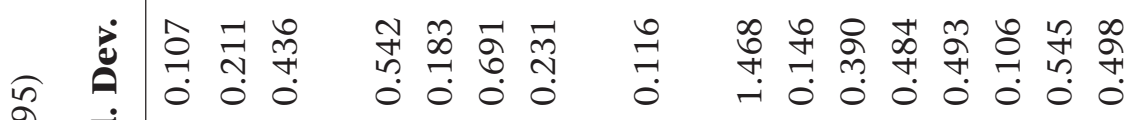

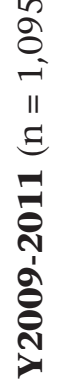

00000000

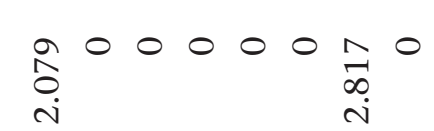

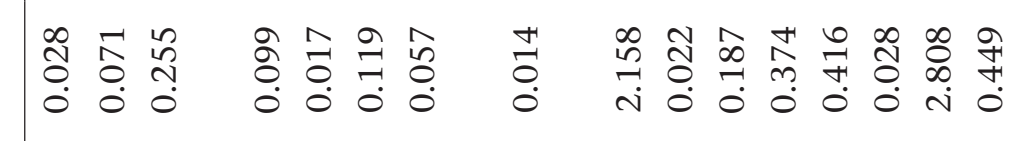

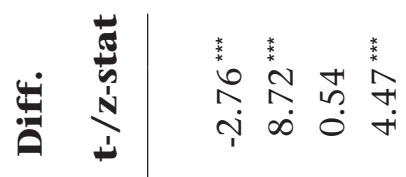

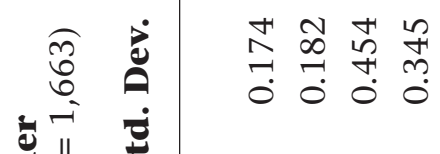

- $-0-0$

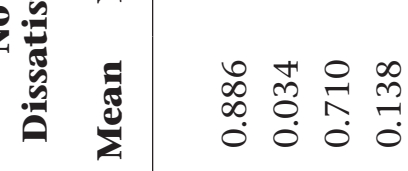

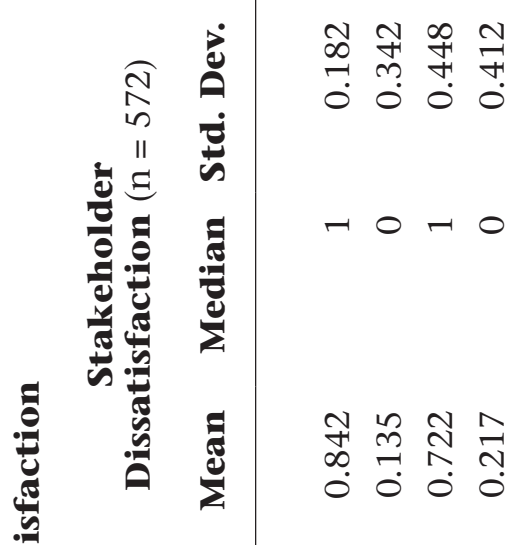

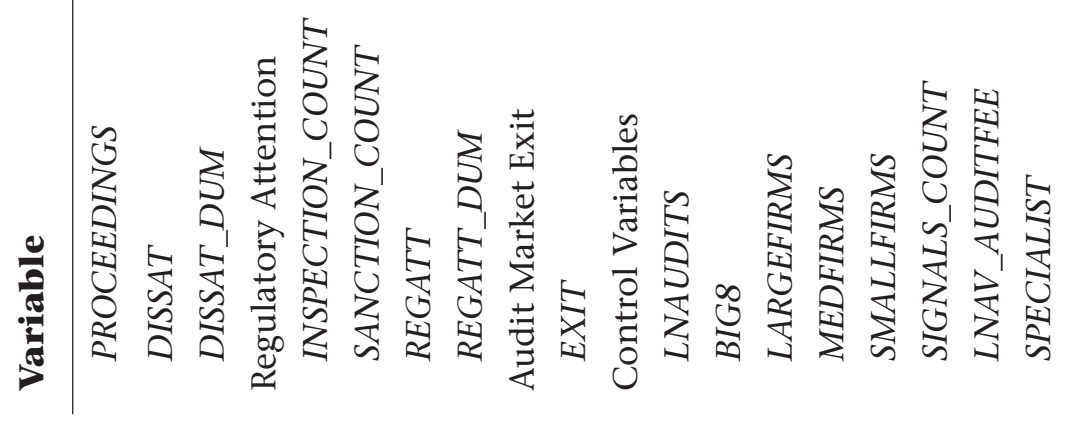

$\stackrel{\mathscr{m}}{\mathscr{y}}$

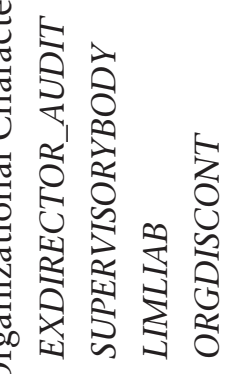




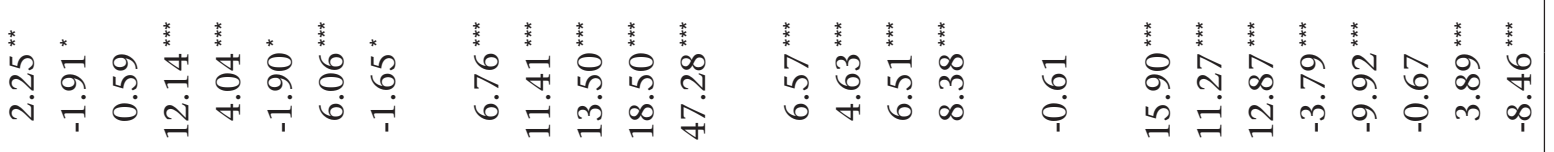

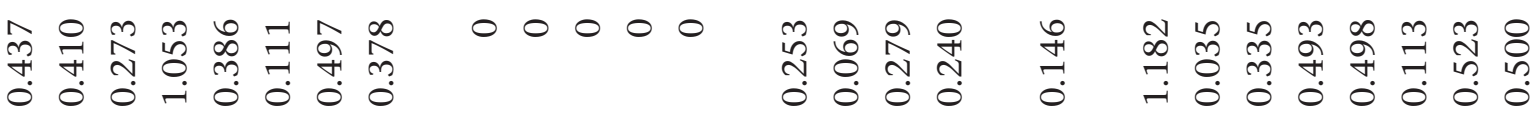

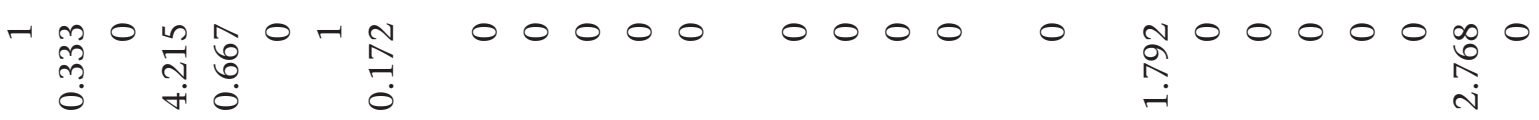

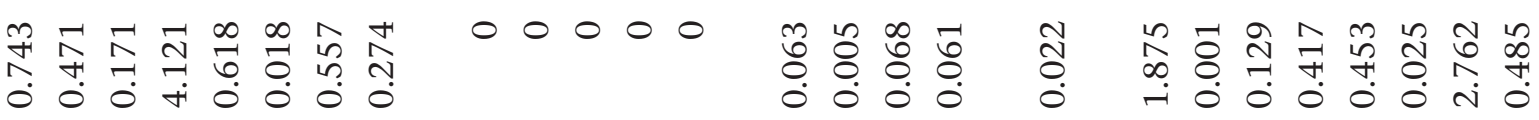

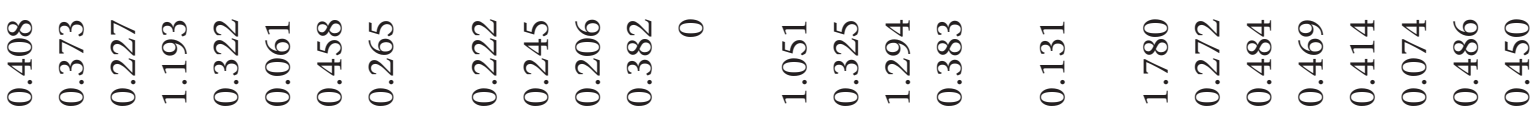

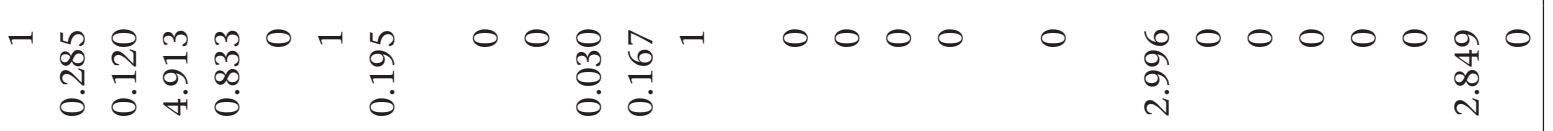

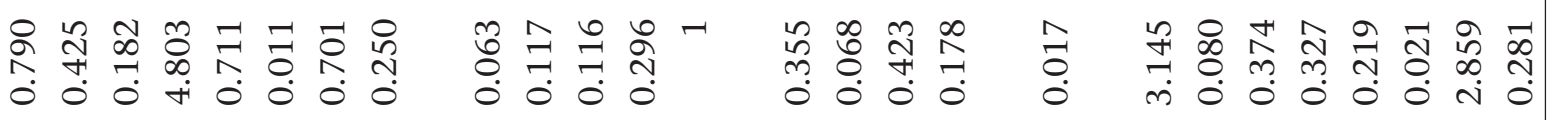

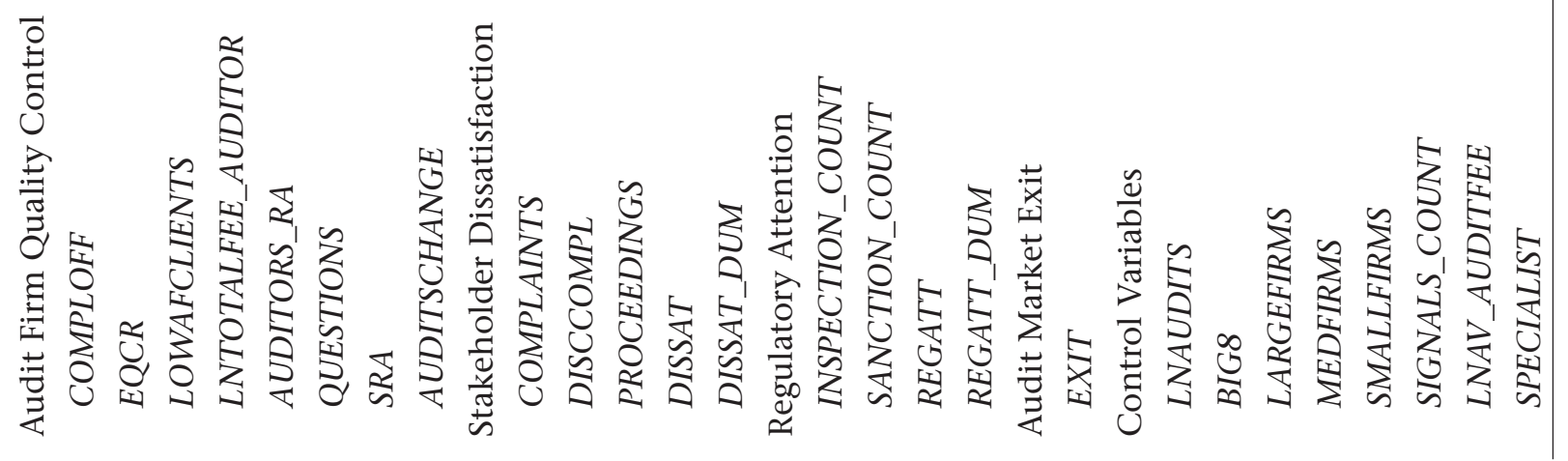




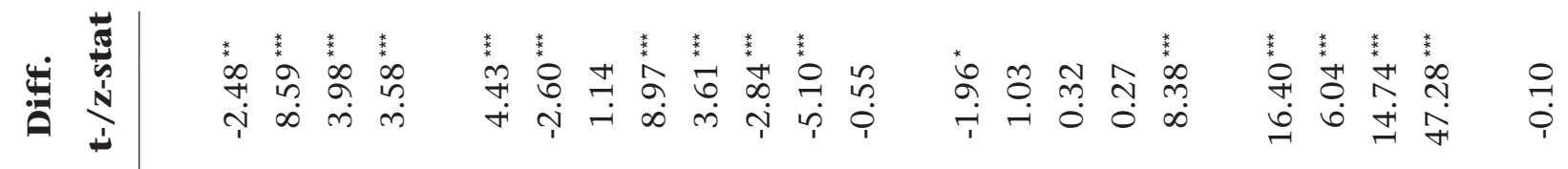

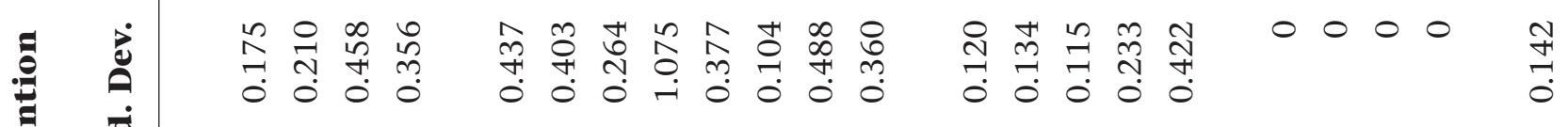

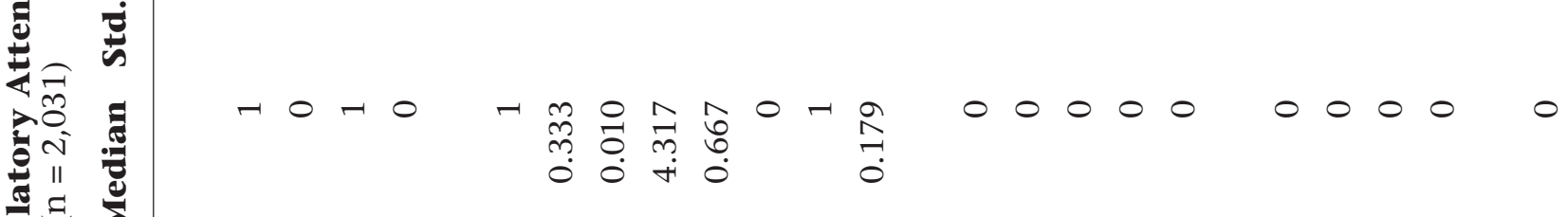

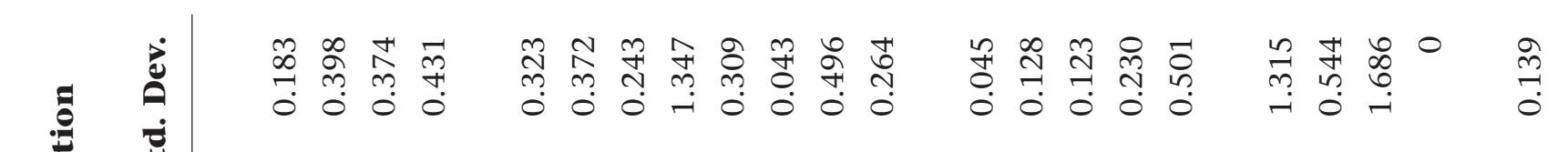

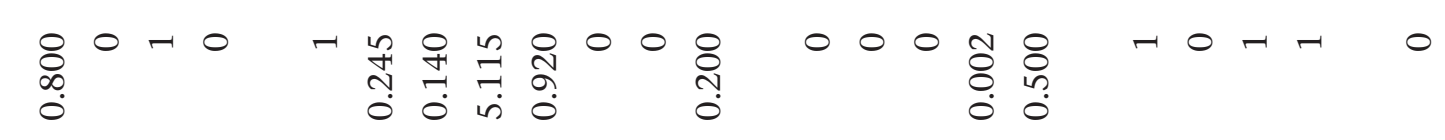

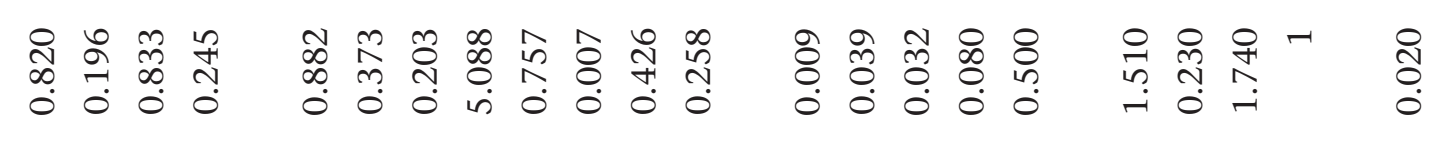

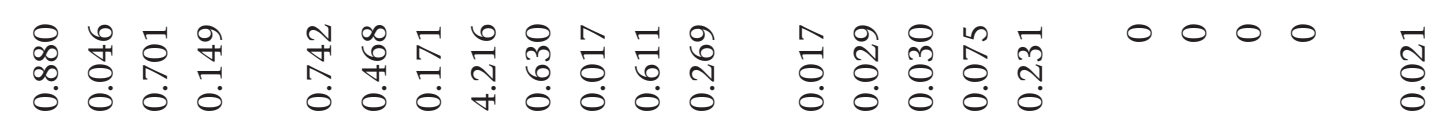
है 胥 


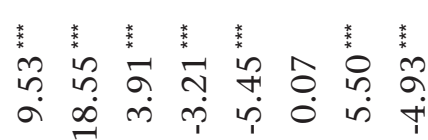

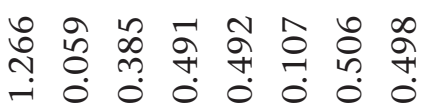

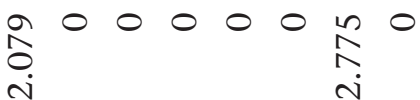

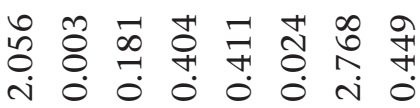

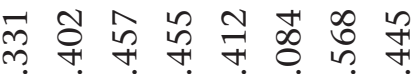
m.

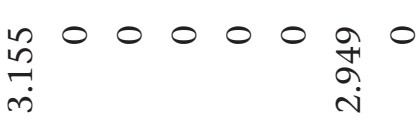

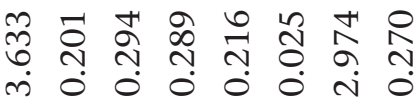

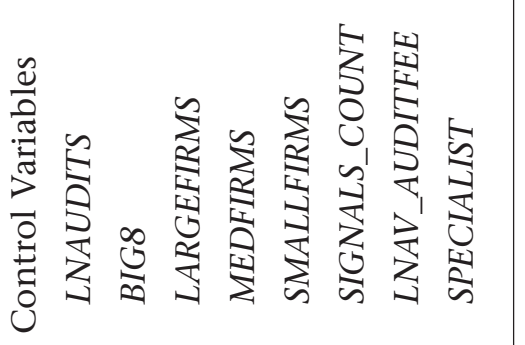




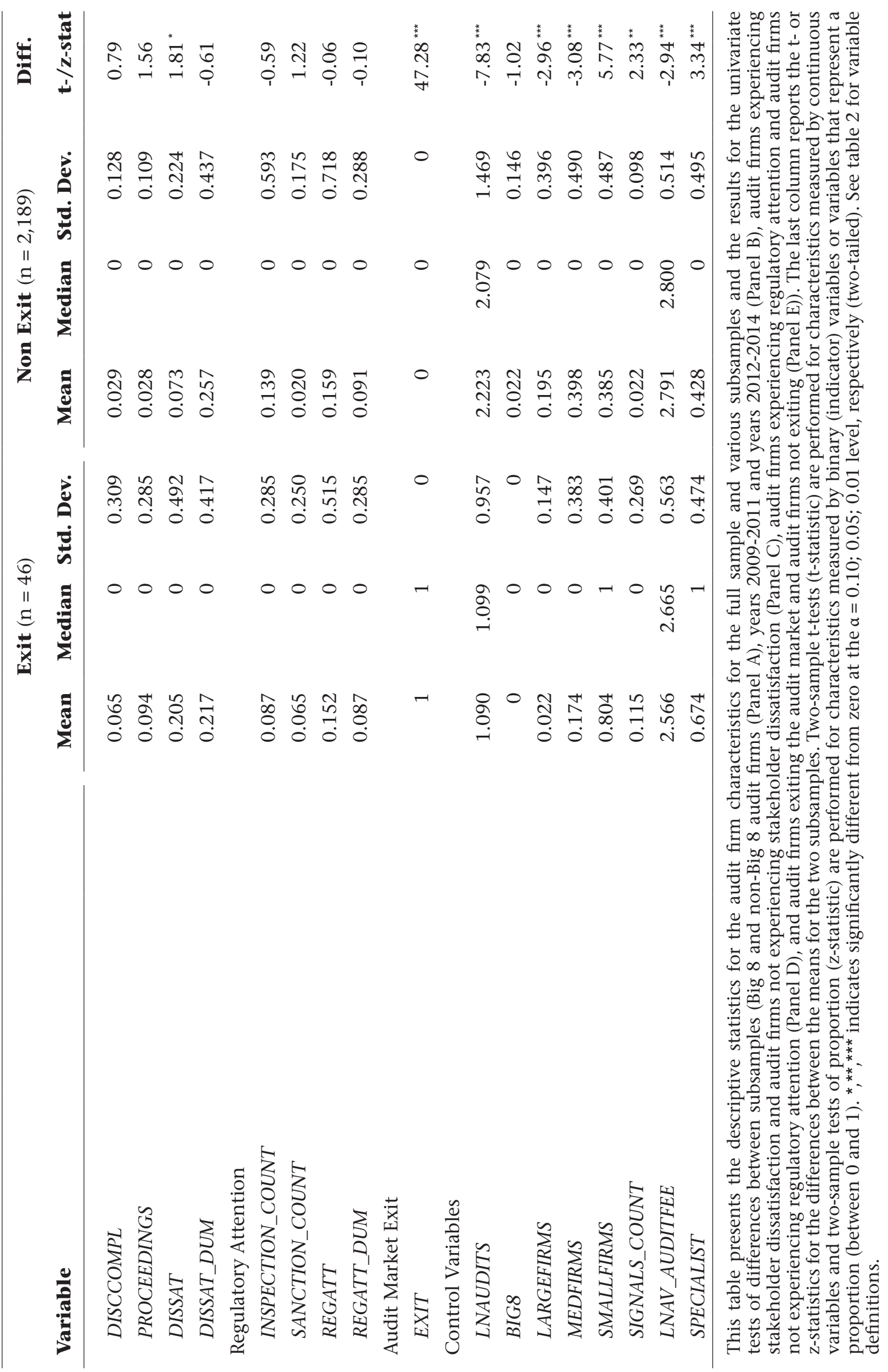


they perform). Non-Big 8 audit firms subject a higher proportion of their non-PIE audit engagements to an EQCR, are more often members of the SRA, and have more volatile engagement portfolios. Big 8 and non-Big 8 audit firms do not significantly differ with regard to the number of clients with relatively low audit fees relative to total fees.

While the average number of stakeholder dissatisfaction issues is smaller for Big 8 audit firms than for non-Big 8 audit firms (2.9 and 7.7 per 100 audits, respectively), almost all Big 8 audit firms (95.8 percent) are faced with at least one such issue (against 24.1 percent of the non-Big 8 audit firms). Big 8 audit firms also experience significantly more regulatory attention. However, none of the Big 8 audit firms exited the audit market in the 2009-2014 period.

The descriptive statistics for the control variables show that Big 8 firms perform more audits, have larger clients (i.e., higher average audit fees per audit engagement), and clients in more different industries (i.e., less often over 60 percent of their clients in the same industry).

Panel B presents the descriptive statistics and univariate test results for two subsamples constructed to measure change over time: it compares the observations in the first three years of public oversight (2009-2011) to those in the later years (20122014). While organizational characteristics appear unchanged, a number of quality control characteristics have changed over time. The percentage of audit firms with a compliance officer has risen significantly (from 54.8 to 95.4 percent). The proportion of non-PIE audits for which an EQCR is performed, has declined, as well as the number of questions asked to the public oversight body. The amount of stakeholder dissatisfaction appears unchanged over time. Regulatory attention has increased, particularly due to an increase in the number of inspections. The number of audit market exits has almost doubled in the second period. The audit firm size variables show a shift in the audit market towards larger firms: the proportion of small firms significantly declined and the proportion of medium-sized firms increased. However, average audit fee per audit engagement declined (which may be due to economic circumstances in the latter period).

Panel C reports the descriptive statistics and univariate test results for the subsamples of audit firms that experienced stakeholder dissatisfaction (DISSAT_DUM= 1) and audit firms that experienced no stakeholder dissatisfaction (DISSAT_DUM $=0$ ). Audit firms experiencing stakeholder dissatisfaction have a lower proportion of auditqualified directors, more often a supervisory body, and more often expected to experience organizational changes or discontinuity in the following year. Audit firms experiencing stakeholder dissatisfaction differ significantly from audit firms without any stakeholder dissatisfaction on almost all quality control characteristics: they have more often appointed a compliance officer, a lower proportion of non-PIE audits with an EQCR, higher total fees per auditor, higher proportion of RA qualified auditors, fewer questions asked to the public oversight body, more often a SRA membership, and less volatile engagement portfolios. Of the audit firms experiencing stakeholder dissatisfaction, a higher proportion is subject to regulatory attention. The audit firm size categories show 
Table 4

\title{
Correlation Matrix
}

\author{
1. DISSAT \\ 2. REGATT \\ 3. EXIT \\ 4. EXDIRECTOR_AUDIT \\ 5. SUPERVISORYBODY \\ 6. LIMLIAB \\ 7. ORGDISCONT \\ 8. COMPLOFF \\ 9. EQCR \\ 10. LOWAFCLIENTS \\ 11. LNTOTALFEE_AUDITOR \\ 12. AUDITORS_RA \\ 13. QUESTIONS \\ 14. SRA \\ 15. AUDITSCHANGE \\ 16. LNAUDITS \\ 17. $B I G 8$ \\ 18. LARGEFIRMS \\ 19. MEDFIRMS \\ 20. SMALLFIRMS \\ 21. SIGNALSCOUNT \\ 22. LNAV_AUDITFEE \\ 23. SPECIALIST
}

\begin{tabular}{|c|c|c|c|c|c|c|c|c|}
\hline $\mathbf{1}$ & 2 & 3 & 4 & 5 & 6 & 7 & 8 & 9 \\
\hline 1.000 & & & & & & & & \\
\hline-0.017 & 1.000 & & & & & & & \\
\hline 0.081 & -0.001 & 1.000 & & & & & & \\
\hline-0.027 & -0.112 & 0.057 & 1.000 & & & & & \\
\hline-0.021 & 0.316 & -0.023 & -0.073 & 1.000 & & & & \\
\hline-0.026 & 0.086 & 0.008 & 0.135 & 0.123 & 1.000 & & & \\
\hline 0.055 & 0.077 & 0.093 & -0.083 & 0.056 & 0.022 & 1.000 & & \\
\hline-0.008 & 0.087 & -0.035 & -0.019 & 0.052 & 0.076 & -0.013 & 1.000 & \\
\hline 0.065 & -0.103 & 0.024 & 0.072 & -0.021 & $-\mathbf{0 . 1 1 5}$ & 0.021 & -0.124 & 1.000 \\
\hline 0.100 & -0.004 & 0.026 & -0.038 & 0.010 & -0.062 & -0.001 & -0.007 & 0.126 \\
\hline-0.061 & 0.305 & -0.108 & -0.166 & 0.241 & 0.085 & 0.100 & 0.129 & $-\mathbf{0 . 1 9 0}$ \\
\hline-0.035 & 0.116 & -0.026 & 0.039 & 0.102 & 0.067 & 0.045 & $\mathbf{0 . 0 8 7}$ & -0.139 \\
\hline 0.010 & -0.027 & -0.024 & 0.045 & 0.002 & -0.010 & 0.013 & -0.054 & 0.038 \\
\hline 0.017 & -0.143 & -0.066 & -0.119 & -0.033 & -0.051 & 0.006 & 0.093 & -0.069 \\
\hline-0.015 & -0.033 & -0.007 & 0.014 & -0.033 & 0.015 & -0.010 & 0.010 & 0.049 \\
\hline-0.072 & 0.444 & -0.110 & -0.189 & 0.378 & 0.126 & 0.115 & 0.138 & -0.275 \\
\hline-0.030 & 0.698 & -0.022 & -0.103 & 0.366 & 0.094 & 0.122 & 0.084 & -0.104 \\
\hline-0.024 & 0.008 & -0.063 & -0.094 & 0.227 & 0.118 & 0.061 & 0.068 & -0.176 \\
\hline-0.052 & -0.097 & -0.065 & -0.055 & $-\mathbf{0 . 1 5 0}$ & -0.052 & -0.003 & 0.026 & -0.069 \\
\hline 0.081 & -0.116 & 0.122 & 0.161 & -0.142 & -0.071 & -0.083 & -0.106 & 0.242 \\
\hline 0.012 & -0.012 & 0.126 & 0.022 & -0.029 & -0.014 & 0.006 & -0.060 & 0.030 \\
\hline-0.026 & 0.225 & -0.062 & -0.047 & 0.086 & 0.026 & 0.033 & 0.042 & 0.093 \\
\hline 0.023 & -0.111 & 0.071 & 0.132 & -0.110 & -0.069 & -0.066 & -0.043 & 0.151 \\
\hline
\end{tabular}

The correlations shown in bold are significant at the $\alpha=0.01$ level. See Table 2 for variable definitions.

that, with stakeholder dissatisfaction measured as an indicator variable, Big 8 and large non-Big 8 audit firms more often experience at least some stakeholder dissatisfaction.

Panel D reports the descriptive statistics and univariate test results for the subsamples of audit firms that experienced regulatory attention $\left(R E G A T T \_D U M=1\right)$ and audit firms that experienced no regulatory attention (REGATT_DUM $=0)$. Apparently, the public oversight body focused its attention on audit firms with a lower proportion of audit-qualified directors, and audit firms that have more often a supervisory body, are more often a legal entity with limited liability, and more often expected some sort of organizational change or discontinuity in the following year. Further, audit firms with regulatory attention more often have a compliance officer, subject a lower proportion of their non-PIE audits to an EQCR, have higher total fees per auditor, higher proportions of auditors with a RA qualification, ask relatively fewer questions to the public oversight body, and are less often SRA members. Also, audit firms with regulatory attention face 


$\begin{array}{llllllllllllll}10 & 11 & 12 & 13 & 14 & 15 & 16 & 17 & 18 & 19 & 20 & 21 & 22 & 23\end{array}$

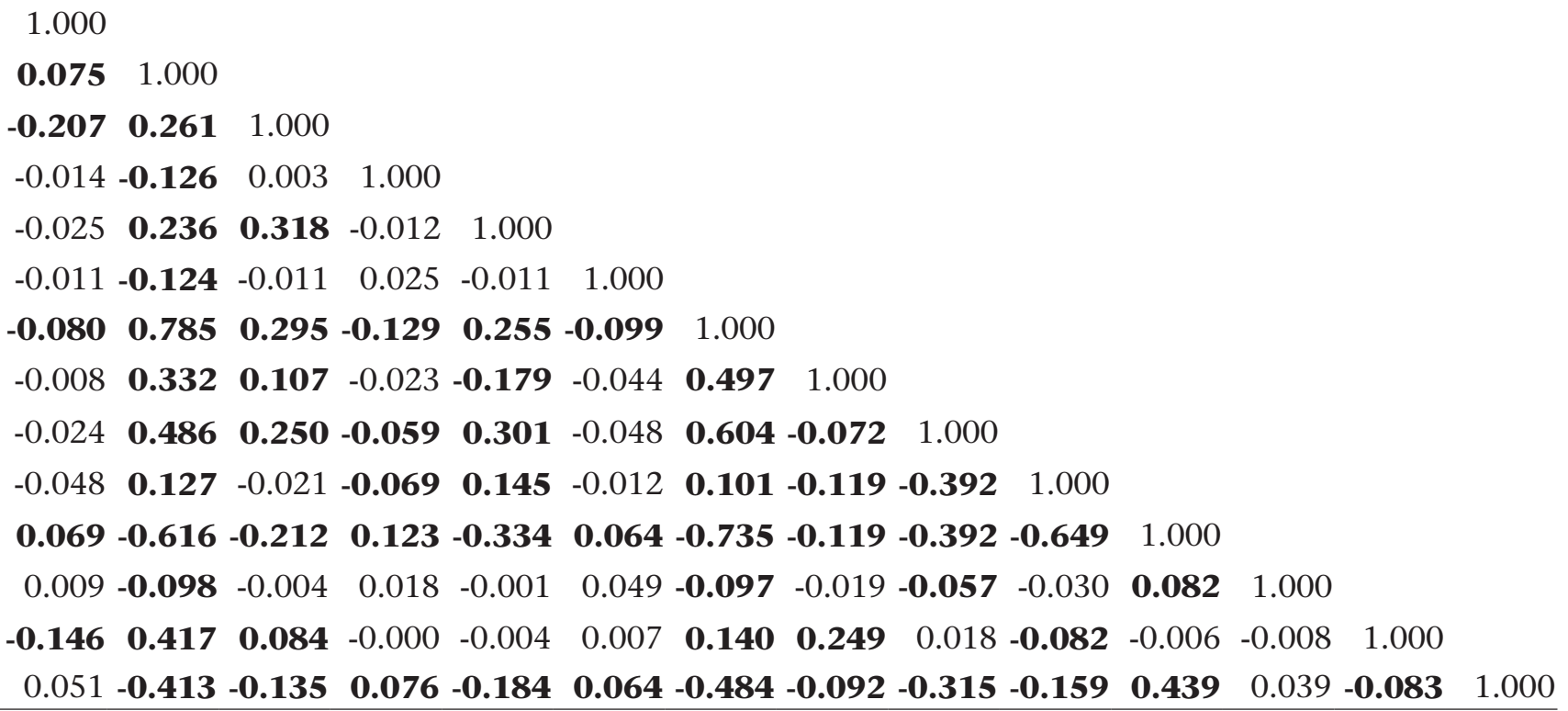

relatively fewer complaints filed directly with the audit firm. However, the proportion of audit firms experiencing regulatory attention are significantly more often facing at least one stakeholder dissatisfaction issue. The audit firm size variables show that, with regulatory attention measured as an indicator variable, Big 8 and large non-Big 8 audit firms are more often experiencing attention from the public oversight body.

Panel E reports the descriptive statistics and univariate test results for the subsamples of audit firms exiting the audit market $(E X I T=1)$ and continuing audit firms $(E X I T=0)$. Exiting firms more often indicated to expect organizational changes or discontinuity in the following year. Concerning quality control characteristics, exiting audit firms have lower total fees per auditor, asked fewer questions to the public oversight body, and are less often SRA members. Stakeholder dissatisfaction is somewhat larger for exiting audit firms: on average they face a higher total number of (disciplinary) complaints and 
proceedings. Regulatory attention appears not significantly different for the two subsamples. The number of signals registered by the public oversight body is larger for audit firms exiting the audit market. Finally, exiting audit firms are most often small firms with fewer audits, smaller clients and more clients in the same industry.

Table 4 presents the Pearson correlation coefficients between the variables included in the estimation model. The absence of very high correlation coefficients and (untabulated) VIF values of well below the commonly used threshold of $10^{16}$, show that the risk of bias in the multivariate analyses due to multicollinearity is minimal (Hair et al. 2006).

\subsubsection{Multivariate Results}

Table 5 reports the results of estimating the multivariate models presented in equation (1) for the three output measures: DISSAT, REGATT and EXIT, respectively. The table reports coefficients estimates and z-values based on standard errors corrected for heteroskedasticity and for clustering of observations by audit firm. All three models are statistically significant $(p<0.001)$.

I first consider the association between the audit firm governance characteristics and the amount of stakeholder dissatisfaction (i.e., the total number of complaints and claims filed directly with the audit firm, complaints filed with the disciplinary court for auditors, and other legal proceedings, scaled by the number of audits performed by the audit firm) by estimating equation (1) using zero-inflated negative binomial regression with DISSAT as the dependent audit firm output variable. As predicted, the results show that audit firms with more stakeholder dissatisfaction have indicated they expect some sort of organizational change or discontinuity in the following year (ORGDISCONT) and have more audit clients with audit fees lower than fees for other services (LOWAFCLIENTS). Further, the results show that these audit firms and are more often SRA member $(S R A) .{ }^{17}$

Next, I consider the association between the audit firm governance characteristics and the level of regulatory attention (i.e., the number of inspections and sanctions) by estimating equation (1) using zero-inflated negative binomial regression with REGATT as the dependent audit firm output variable. As predicted, the results show that audit firms receiving more regulatory attention have a lower proportion of audit-qualified directors (EXDIRECTOR_AUDIT), have more audit clients with audit fees lower than fees for other services (LOWAFCLIENTS), are less often SRA member (SRA), and have more signals

\footnotetext{
16 The highest VIF value for an individual variable is 4.87 and the average VIF values for the regressions for the three output measures are $1.65,1.63$, and 1.70 , respectively.

17 Note that the variable $S R A$ has a coefficient with a sign opposite of the one predicted. Regarding the positive association between stakeholder dissatisfaction and SRA membership, one could speculate that stakeholders find easier excess to complaints procedures when the audit firms are recognizably member of a collective association promoting high quality.
} 
registered by the public oversight body (SIGNALSCOUNT $)^{18}$. I also include the variable DISSAT as an independent variable and find no association between stakeholder dissatisfaction and regulatory attention. However, additional analysis (untabulated; excluding observations for the year 2009) shows that the lagged values for DISSAT are significantly associated with more regulatory attention. Further, the results show that audit firms receiving more regulatory attention have more auditors with a university level education (AUDITORS_RA $)^{19}$, more audit clients (LNAUDITS) and larger audit clients (LNAV_AUDITFEE). These results suggest that the public oversight body focuses its attention on larger audit firms with more audit-oriented auditors ${ }^{20}$ and on audit firms with a higher 'risk profile' (i.e., audit firms with a higher proportion of non-auditors on the board of directors, more audit clients with audit fees lower than fees for other services, not subject to SRA quality reviews, with increased stakeholder dissatisfaction in the previous year, and with a higher cumulative number of registered signals).

Lastly, I consider the probability of an audit firm exiting the statutory audit market by estimating equation (1) using probit regression with EXIT as the dependent audit firm output variable. As predicted, the results show that audit firms that exit the statutory audit market have indicated they expect some sort of organizational change or discontinuity (ORGDISCONT), less often have appointed a compliance officer (COMPLOFF), have fewer audit clients (LNAUDITS) and smaller audit clients (LNAV $A U D I T F E E)$, and have more signals registered by the public oversight body (SIGNALSCOUNT). I also include the variables DISSAT and the lagged value of REGATT as independent variables and find that audit firms that exit the statutory audit market are associated with more stakeholder dissatisfaction and more regulatory attention in the previous year $\left(R E G A T T \_L A G\right) .{ }^{21}$ Further, the results show exiting firms have a higher

18 In the analysis of REGATT, the variable SIGNALSCOUNT is measured as the cumulative number of signals registered by the public oversight body up to that year, since the public oversight body is expected to increase its attention for a particular audit firm based on the total number of signals registered rather than the number of signals registered within that year. Additional analysis (untabulated) show that the number of signals in a specific year is not significantly associated with regulatory attention.

19 Note that the variable AUDITORS_RA has a coefficient with a sign opposite of the one predicted. Although more academically educated auditors were expected to be a sign of stronger audit firm governance and to be associated with less regulatory attention, an alternative explanation could be that the public oversight body focuses its attention on audit firms that are more specialized in performing audits, which are more often performed by RA qualified auditors, rather than on performing administrative services, mostly performed by AA qualified auditors.

20 Registered accountants (RA), who have completed university-level education, are more specialized in performing audits, while accounting administration consultants (AA), who have completed higher vocational education, are more specialized in providing administrative services to mid-sized and smaller companies.

21 Additional analysis (untabulated) shows that current year's regulatory attention (REGATT) is insignificantly associated with an audit market exit, suggesting that the public oversight body's inspection and sanctions have a lagged effect on the audit firm's decision to exit the audit market. 
proportion of audit-qualified directors (EXDIRECTOR_AUDIT). ${ }^{22}$ These results suggest that audit firms that exit the statutory audit market are smaller and more often experiencing 'trouble' (i.e., a higher likelihood of expected organizational change or discontinuity, more stakeholder dissatisfaction, increased regulatory attention in the previous year, and more signals registered by the public oversight body). Furthermore, these results suggest that exiting audit firms did not make the quality investment of appointing a compliance officer, while on average the percentage of audit firms with a compliance officer had increased from 55 percent in the earlier years of public oversight (2009-2011) to 95 percent in the later years (2012-2014) (see Table 3, Panel B).

Overall, I find some support for all three posited hypotheses that stronger audit firm governance mechanisms are associated with less stakeholder dissatisfaction, less regulatory attention, and more audit market exits, albeit to a different extent.

\subsubsection{Sensitivity Analyses}

I perform several sensitivity tests (untabulated) for the results presented in Table 5. First, I run an analysis for only non-Big 8 observations. For the analysis of REGATT the results are qualitatively similar to those presented in Table 5. For DISSAT, the variable SRA is insignificant for the non-Big 8 observations. For EXIT, the variable LNAV_AUDITFEE is insignificant.

Second, I perform the regressions separately for the periods 2009-2011 and 20122014. In the analysis of stakeholder dissatisfaction, the results show that the association with ORGDISCONT and LOWAFCLIENTS are significant in both periods. The variable $S R A$, which is significant in the overall time period, is not significant in the two separate periods. In the period 2009-2011, audit firms with lower client portfolio volatility (AUDITSCHANGE) experience more stakeholder dissatisfaction. The public oversight body appears to have focused its attention in the earlier period (2009-2011) on audit firms with a lower proportion of audit-qualified directors (EXDIRECTOR_AUDIT), withoutSRA membership (SRA), with higher client portfoliovolatility (AUDITSCHANGE), and with more and larger audit clients (LNAUDITS and LNAV_AUDITFEE, respectively). Its attention appears to take into consideration a number of additional audit firm characteristics in the later period (2012-2014) (i.e., LOWAFCLIENTS, AUDITORS_RA, DISSAT, and SIGNALSCOUNT). In addition to the significant variables presented in Table 5 , audit firms exiting the statutory audit market in the earlier period are associated with a higher proportion of audit clients for which audit fees are smaller than fees for other services (LOWAFCLIENTS) and lower client portfolio volatility (AUDITSCHANGE).

\footnotetext{
22 This result is inconsistent with the predicted negative sign for this variable. This may be due to its relation with audit firm size. Untabulated results show that the average proportion of auditqualified directors decreases with audit firm size (75.1 percent for Big 8 audit firms, 84.1 percent for large non-Big 8 audit firms, 86.3 percent for medium-sized non-Big 8 audit firms, and 91.0 percent for small non-Big 8 audit firms). As described later, sensitivity analyses show that particularly the smallest audit firms exit the statutory audit market.
} 
However, they appear not associated with having a compliance officer (COMPLOFF), stakeholder dissatisfaction (DISSAT), regulatory attention (REGATT), the number of audit clients (LNAUDITS) or audit client size (LNAV_AUDITFEE). In the later period, in addition to the significant variables presented in Table 5 , audit firms exiting the statutory audit market are more often organized as legal entities with limited liability (LIMLIAB) and have a lower proportion of audit clients for which audit fees are smaller than fees for other services (LOWAFCLIENTS). The proportion of audit-qualified directors (EXDIRECTOR_AUDIT) and the number of registered signals (SIGNALSCOUNT) are insignificant in this later period.

Third, I use alternative audit firm size measures and replace LNAUDITS by three indicator variables in the estimation model: BIG8, LARGEFIRMS, and MEDFIRMS (with the small audit firms as the reference category). The results show a negative association between the Big 8 and medium-sized non-Big 8 indicator variables and stakeholder dissatisfaction, suggesting that particularly the large non-Big 8 and smallest audit firms experience more stakeholder dissatisfaction. ${ }^{23}$ Further, the analysis of REGATT including these audit firm size measures shows that the public oversight body particularly focuses its attention on the Big 8 and large non-Big 8 audit firms. Finally, the analysis of EXIT shows that the smallest audit firms are more inclined to exit the audit market.

Fourth, excluding the output variables DISSAT and REGATT as independent variables from the analyses on REGATT and EXIT respectively, leaves the results for the audit firm governance characteristics qualitatively similar.

Finally, in order to test whether the audit firm governance characteristics have a lagged association with the audit firm output variables, I re-perform the analyses with next year's audit firm output measures. Compared with the results presented in Table 5, next year's stakeholder dissatisfaction is associated positively with ORGDISCONT, EQCR and LOWAFCLIENTS, and negatively with COMPLOFF, but not with SRA. Next year's regulatory attention is negatively associated with LNTOTALFEE_AUDITOR and positively associated with DISSAT in addition to the significant variables for this year's regulatory attention, indicating that there is a time lag for the public oversight body to take auditor workloads and stakeholder dissatisfaction into consideration. Next year's audit market exits appear only associated with the audit firm indicating to expect some sort of organizational change or discontinuity in the following year (ORGDISCONT), higher auditor workloads (LNTOTALFEE_AUDITOR), more regulatory attention (REGATT), and fewer and smaller audit clients (LNAUDITS and LNAV_AUDITFEE, respectively).

23 This finding may be due to the scaling method applied. The total number of complaints and proceedings are scaled by the total number of audits performed by the audit firm. The results indicate that, compared to the total client portfolio size, smaller firms receive relatively more complaints and proceedings. In absolute terms, the total number of complaints and proceedings is larger for the larger audit firms. 
Table 5

Multiple Regressions for Stakeholder Dissatisfaction, Regulatory Attention and Audit Market Exits

\begin{tabular}{|c|c|c|c|c|c|c|c|}
\hline \multirow[b]{3}{*}{ Independent Variables } & \multirow{3}{*}{$\begin{array}{l}\text { Pred. } \\
\text { Sign }\end{array}$} & \multicolumn{6}{|c|}{ Dependent Variables: } \\
\hline & & \multicolumn{4}{|c|}{ REGATT } & \multicolumn{2}{|c|}{ EXIT } \\
\hline & & Coef. $z$ & -stat. & Coef. $z$ & -stat. & Coef. & z-stat. \\
\hline \multicolumn{8}{|l|}{ Organizational Characteristics } \\
\hline EXDIRECTOR_AUDIT & - & -0.532 & -1.24 & -1.018 & $-2.05^{* *}$ & 1.062 & $2.31^{* *}$ \\
\hline SUPERVISORYBODY & - & -0.011 & -0.05 & -0.135 & -0.59 & -0.041 & -0.09 \\
\hline LIMLIAB & + & 0.010 & 0.05 & 0.253 & 0.94 & 0.149 & 0.90 \\
\hline ORGDISCONT & + & 0.453 & $2.76^{\star \star \star}$ & -0.032 & -0.24 & 0.831 & $5.95^{\star \star \star}$ \\
\hline \multicolumn{8}{|l|}{$\begin{array}{l}\text { Audit Firm Quality Control } \\
\text { COMPLOFF }\end{array}$} \\
\hline$E Q C R$ & - & 0.280 & 1.53 & 0.023 & 0.09 & 0.088 & 0.52 \\
\hline LOWAFCLIENTS & + & 0.886 & $2.91^{* * *}$ & 0.925 & $2.17^{\star *}$ & -0.019 & -0.08 \\
\hline LNTOTALFEE_AUDITOR & + & -0.164 & -1.15 & -0.257 & -1.49 & 0.052 & 0.44 \\
\hline AUDITORS_RA & - & -0.016 & -0.07 & 0.739 & $2.12^{* *}$ & -0.139 & -0.75 \\
\hline QUESTIONS & - & -0.035 & -0.05 & -0.449 & -0.38 & $\mathrm{NA}^{\mathrm{a}}$ & \\
\hline$S R A$ & - & 0.294 & $1.68^{*}$ & -1.044 & $-4.71^{* * *}$ & -0.007 & -0.04 \\
\hline AUDITSCHANGE & + & -0.205 & -0.96 & 0.277 & 1.26 & -0.200 & -1.05 \\
\hline $\begin{array}{l}\text { Stakeholder Dissatisfaction } \\
\quad \text { DISSAT }\end{array}$ & + & & & 0.425 & 1.52 & 0.369 & $2.18^{\star *}$ \\
\hline $\begin{array}{l}\text { Regulatory Attention } \\
\text { REGATT_LAG }\end{array}$ & + & & & & & 0.418 & $3.92^{* \star *}$ \\
\hline $\begin{array}{l}\text { Control Variables } \\
\text { LNAUDITS }\end{array}$ & - & -0.092 & -0.84 & 0.649 & $6.69^{* * *}$ & -0.400 & $-3.44^{* * *}$ \\
\hline SIGNALSCOUNT ${ }^{\mathrm{c}}$ & + & 0.090 & 0.17 & 0.469 & $2.11^{* *}$ & 0.956 & $2.51^{* *}$ \\
\hline LNAV_AUDITFEE & $?$ & 0.082 & 0.51 & 0.480 & $2.46^{\star \star}$ & -0.323 & $-1.83^{\star}$ \\
\hline SPECIALIST & $?$ & -0.095 & -0.62 & -0.030 & -0.18 & 0.023 & 0.15 \\
\hline Constant & & -1.917 & $-3.39^{* * *}$ & -4.157 & $-4.82^{* * *}$ & -2.565 & $-3.90^{* * *}$ \\
\hline Fixed effects & & & YEAR & & YEAR & & YEAR \\
\hline Observations & & & 2,235 & & 2,235 & & 2,235 \\
\hline Wald chi2 & & & 61.63 & & 989.55 & & 147.00 \\
\hline Pseudo $\mathrm{R}^{2}$ & & & $\mathrm{~b}$ & & $\mathrm{~b}$ & & 0.244 \\
\hline
\end{tabular}


Table 5 - continued

\begin{abstract}
This table reports the results for the model presented in equation (1). For the regression on DISSAT and REGATT zero-inflated negative binomial regressions were performed. For the regression on EXIT a probit regression was performed. The table reports coefficients estimates and z-values based on standard errors corrected for heteroskedasticity and for clustering of observations by audit firm. ${ }^{*},{ }^{* *},{ }^{* * *}$ indicates significant at the $\alpha=0.10 ; 0.05 ; 0.01$ level, respectively (two-tailed). See Table 2 for variable definitions.

a Since none of the exiting audit firms asked questions to the public oversight body, the variable QUESTIONS is dropped to avoid multicollinearity.

b STATA does not provide a (pseudo) $\mathrm{R}^{2}$ value for zero-inflated negative binomial regressions.

c In the analysis of REGATT, the variable SIGNALSCOUNT is measured as the cumulative number of signals registered by the public oversight body up to that year, rather than the number of signals registered within that year.
\end{abstract}

\title{
4.6 Conclusion
}

In this study, I examine the association between audit firm governance characteristics and three firm-level output measures of audit quality: (a) stakeholder dissatisfaction; (b) regulatory attention; and (c) audit market exits. The purpose was to identify audit quality indicators and increase the understanding of audit firms and their governance. Based on prior studies-albeit limited in number-and on the assumptions underlying audit firm governance regulation, I hypothesize audit firms with stronger governance mechanisms in place to be of higher quality (i.e., be confronted with less stakeholder dissatisfaction, trigger less regulatory attention, and/or a lower likelihood to exit the audit market). I operationalize audit firm governance by constructing organizational and quality control variables. This study includes all audit firms active in the statutory audit market in the Netherlands. Data on audit firm characteristics are obtained from the proprietary files of the Dutch audit oversight body, the AFM, since they are for the most part not publicly disclosed.

Descriptive statistics and univariate tests show that many audit firm governance characteristics are significantly different for Big 8 and non-Big 8 audit firms, for the earlier and later years of public oversight, and whether or not the audit firm faced stakeholder dissatisfaction, experienced increased regulatory attention or exited the audit market. Multivariate analyses provide support that several audit firm governance characteristics are associated with distinct firm-level output measures of audit quality. Specifically, the results show that audit firms with expected organizational change or discontinuity, and with more clients for which they provide more non-audits services than audit services, are experiencing higher levels of stakeholder dissatisfaction. The public oversight body appears to focus its attention on larger audit firms with more audit-oriented auditors and on audit firms with a higher 'risk profile' (i.e., audit firms with a higher proportion of non-auditors on the board of directors, a higher proportion of audit clients for which audit fees are smaller than fees for other services, not subject to SRA quality reviews, with increased stakeholder dissatisfaction in the previous year, and 
with a higher cumulative number of registered signals). Audit firms that exit the statutory audit market appear to be smaller, more often experiencing 'trouble' (i.e., a higher likelihood of expected organizational change or discontinuity, more stakeholder dissatisfaction, increased regulatory attention in the previous year, and more signals registered by the public oversight body), and less likely to have made the quality investment of appointing a compliance officer. Interestingly, additional tests provide evidence that the number of audit firm governance characteristics that are significantly associated with the output measures has increased over time, suggesting that their informational value has improved.

I acknowledge a number of limitations in this study. The analyses may suffer from endogeneity bias. First, the proxies used to measure audit firm governance may be subject to measurement error (e.g., Casterella et al. 2010). Most proxies used are 'quantifications' of governance characteristics that might be more appropriately measured more qualitatively. A further limitation of these proxies is that they are typically measured dichotomously, which implicitly assumes a homogeneous level of audit quality within each group (DeFond and Zhang 2014). Second, this study is merely one of association: causal inferences are not possible. The determination of any causal direction may be difficult: audit firm governance characteristics are expected to influence the likelihood of stakeholder dissatisfaction, regulatory attention, and audit market exits, while at the same time these measures may influence audit firm governance. Third, although statistical tests (i.e., correlations and VIF values) indicate a low risk of bias due to multicollinearity, it may still be that some characteristics, audit firm size in particular, are determining the levels of other characteristics. Finally, the analyses may suffer from omitted variables. Although this study already incorporates 3 distinct firm-level audit quality measures, 12 audit firm governance characteristics, and 4 other audit firm-level control variables, these may still not grasp the full complexity of the entire audit (firm) quality concept. It may be that more consistent associations could be found between the audit firm governance characteristics and engagement-level audit quality proxies, rather than the audit firm-level quality proxies used in this study. Future research may attempt to overcome these limitations by employing alternative definitions of audit firm governance characteristics or other audit quality measures. 
Chapter 5

Conclusion 
The three studies in this dissertation examine audit quality in a regulatory context and focus on three distinct features of this regulatory context: public oversight, auditor independence, and audit quality indicators. In this final chapter, I first summarize the results from the three studies. Second, I discuss the inherent limitations and main contributions of this dissertation. Finally, I discuss the main implications and provide suggestions for further research.

\subsection{Summary of Results}

In the first study, presented in Chapter 2, the effectiveness of public oversight is examined by testing whether (a) the public oversight body can differentiate audit quality in its first-time inspection round, and (b) audit quality improves after the first-time inspection round. In particular, it is tested whether there is an association between the outcome of the first-time inspections (i.e., 'material findings' or 'no material findings') and the level of earnings quality, and any subsequent change in earnings quality, of companies audited by the inspected audit firms.

Based on a sample of first-time inspection reports of 51 audit firms covering over 85 percent of the statutory audit market in the Netherlands, and relating to 6,609 client company-year observations over the years 2005-2008, the results show that companies audited by audit firms with material findings in their first-time inspections by the public oversight body have lower earnings quality than companies audited by audit firms without material findings. This finding holds for audit firms with and without PIE clients, except for the group of smallest non-PIE audit firms. However, the evidence does not provide support for an improvement in audit quality after the first inspection round, which is arguably the most important aspect of effective public oversight. This finding is in contrast to U.S. evidence suggesting an improvement in audit quality after PCAOB inspections. One possible explanation for this difference in findings is that audit firmspecific inspection reports in the Netherlands were not publicly disclosed up until 2014.

In further analyses, it is found that the type of deficiencies identified by the public oversight body that are most able to distinguish audit quality are related to the performance and documentation of audit engagements, independence, and quality reviews. Furthermore, no support is found for an association between the prior peer review outcomes of audit firms and the audit clients' earnings quality. This suggests that the prior Dutch peer review system appeared to be 'friendly', which may notbeunexpected given that audit firms were allowed to select their own peer reviewer, and is also consistent with prior findings. There is also no support that audit quality improved after peer review outcomes. Collectively, it is concluded that the public oversight body is able to distinguish audit quality, in contrast with the prior peer review system, but both systems do not appear to bring about improvement in audit quality.

In the second study, presented in Chapter 3, the effectiveness of auditor independence regulation is examined by assessing how audit firms adjust their efforts 
and/or risk premiums when they maintain a business relationship with an audit client. Specifically, the association is examined between the existence of an audit firm-client business relationship and audit quality, inferred from both audit fees and earnings quality.

Based on a sample of Dutch companies maintaining a business relationship with their audit firm each matched with similar Dutch companies without such business relationships, business relationships are found consistently associated with higher audit fees and, particularly in those situations where the business relationship coincides with high non-audit fees relative to audit fees, with higher earnings quality. These results suggest that audit firms consider the business relationship a threat to the auditor's independence and attempt to mitigate this threat with safeguards, as required by the independence regulation, such as additional audit or review efforts, or other quality control measures. However, alternative explanations for higher audit fees, such as the audit firm charging a risk premium to the audit client, are not completely ruled out. Importantly, no evidence of impaired independence was found, which would likely have resulted in lower audit fees and lower earnings quality. These results appear robust for a number of sensitivity tests on cross-sectional subsamples (e.g., based on the audit firm size (Big 4 or non-Big 4), type of audit client (PIE or non-PIE), demand for audit quality, and client risk), as well as for an alternative measure of business relationships (i.e., the monetary value of these business relationships) and alternative matching methods.

In the third study, presented in Chapter 4, it is examined whether audit firm governance characteristics are useful audit quality indicators. This is done by testing whether audit firms with stronger governance mechanisms in place are less likely to be confronted with stakeholder dissatisfaction, trigger regulatory attention, or exit the audit market. Audit firm governance is operationalized by constructing organizational variables and quality control system variables.

Based on a sample of all active audit firms licensed to perform statutory audits in the Netherlands, univariate test results show that many audit firm governance characteristics are significantly different for Big 8 and non-Big 8 audit firms, for earlier versus later years of public oversight, and whether or not audit firms faced stakeholder dissatisfaction, experienced increased regulatory attention or exited the audit market. Multivariate analyses provide support that several audit firm governance characteristics are associated with distinct firm-level output measures of audit quality, albeit to a differentextent.Specifically, theresultsshow thatauditfirms withexpected organizational change or discontinuity, and with more clients for which they provide more non-audits services than audit services, are experiencing higher levels of stakeholder dissatisfaction. The public oversight body appears to focus its attention on larger audit firms with more audit-oriented auditors and on audit firms with a higher 'risk profile' (i.e., audit firms with a higher proportion of non-auditors on the board of directors, a higher proportion of audit clients for which audit fees are lower than fees for other services, not subject to SRA quality reviews, with increased stakeholder dissatisfaction in the previous year, with a higher cumulative number of registered signals). Audit firms that exit the statutory 
audit market appear to be smaller, more often experiencing 'trouble' (i.e., a higher likelihood of expected organizational change or discontinuity, more stakeholder dissatisfaction, increased regulatory attention in the previous year, and more signals registered by the public oversight body), and less likely to have made the quality investment of appointing a compliance officer. Interestingly, additional tests provide evidence that the informational value of the audit firm governance characteristics has increased over time.

\subsection{Limitations}

Although the research in this dissertation has been carefully designed, I acknowledge a number of inherent limitations common to archival auditing research. All three studies make use of proxies for audit quality, i.e., variables that are indirect measures of actual audit quality, that may be subject to measurement error. Abnormal accruals measure earnings quality, which is also influenced by factors other than audit quality. This means low audit quality will not necessarilybe associated with low earnings quality. Furthermore, using abnormal accruals in the studies limits the sample size to those audit firms with sufficient audit client financial data to calculate those accruals (i.e., mostly larger audit firms with larger audit clients) and excludes certain audit client industries (i.e., financials and utilities). This is particularly the case for the study presented in Chapter 2 and to a lesser extent to the study presented in Chapter 3. The results from those studies may not be generalizable to other, smaller, audit firms. The audit fees used in the study presented in Chapter 3 are known to not only measure audit effort, but also the auditor's risk premium for expected legal liability as well as audit efficiency, which may be difficult to entangle. However, more direct measures of audit quality, like restatements, are not readily available in the Netherlands, and the limited number of bankrupt companies in the sample periods prevents a feasible analysis using going concern opinions.

The studies presented in Chapters 3 and 4 may further suffer from some omitted correlated variables. There may be additional variables that simultaneously affect both the occurrence of a business relationship between the audit firm and the audit client, and audit fees (Chapter 3). Further, the study presented in Chapter 4 only incorporates audit firm-level quality measures, where (additional) engagement-level audit quality proxies might have been more effective.

Each of the three studies is subject to one or more additional and specific limitations. The study presented in Chapter 2 focuses only on first-time inspections. It is unknown whether the inspection outcomes in subsequent rounds continue to be signaling or improve audit quality. Furthermore, the study covers a relatively long time period, i.e., from 2003 to 2008 including the peer review analysis, and ends in a known financial crisis, which makes the interpretation of any change in earnings quality difficult. It is also unknown whether the time gap between the abnormal accruals related to the public oversight outcome data and the abnormal accruals related to the peer 
review outcome data, affects the results. There are some limitations caused by the use of the propensity-score matching approach to construct the research sample for the study presented in Chapter 3. The findings may not be generalizable to the full population. Since the study described in Chapter 3 only finds limited evidence of increased audit quality (i.e., proxied by lower abnormal total accruals), alternative explanations for increased audit fees should not be completely ruled out. It is for instance possible that audit clients are simply more willing to pay higher audit fees to the audit firm, when the audit firm pays good money for the goods or services delivered by the audit client to the audit firm, which could be characterized by reciprocal trust. The study presented in Chapter 4 uses proxies that are mostly 'quantifications' of governance characteristics that might be more appropriately measured in a more qualitative way. A further limitation of these proxies is that they are typically measured dichotomously, which implicitly assumes a homogeneous level of audit quality within each group.

Finally, it should be noted that all three studies are measuring association, not causation, which calls for cautious interpretation of the results.

\subsection{Contribution}

This dissertation contributes to the auditing literature in several ways. In particular, it sheds new light on various audit quality aspects by using proprietary data from the Dutch public oversight body. The study presented in Chapter 2 employs non-public data on first-time inspections outcomes (i.e., 'material findings' or 'no material findings', including detailed information on the types of deficiencies identified by the public oversight body), which adds to the literature on public oversight effectiveness as well as on the audit firm quality control system aspects that are most able to differentiate audit quality. The study presented in Chapter 3 contributes to the literature on auditor independence by examining a previously unstudied type of independence threat using data on business relationships between audit firms and audit clients obtained by the public oversight body in its 2011 thematic review on auditor independence. The nature and monetary value of these relationships illustrate their economic significance for both the audit firm and the audit client. Furthermore, the proprietary data enabled the inclusion of smaller non-PIE companies for which audit fee data had otherwise been unavailable. The study presented in Chapter 4 contributes to the growing literature on audit quality indicators by examining the association between several non-public audit firm governance characteristics and three firm-level output measures of audit quality (i.e., stakeholder dissatisfaction, regulatory attention, and audit market exits). The characteristics and measures are mostly non-public and obtained from the public oversight body's yearly monitoring questionnaire and its internal records of audit firm registrations, notifications, signals, inspections, and sanctions. 
While most auditing research is U.S.-based, all three studies in this dissertation are set in the Dutch audit market. The Netherlands is an interesting and distinct setting for multiple reasons. Prior auditing studies have shown that audit quality differs across countries and that the quality of the institutional setting and the risk of litigation are important determinants of audit quality(e.g., Francis and Wang 2008). The Dutch audit market is characterized by a low litigious setting, which weakens the extent to which the auditor's wealth serves as a bond for audit quality and increases moral hazard risk. There may be a greater need for effective audit regulation and public oversight to control for those risks, making the association of this regulation and public oversight with audit quality more important. Furthermore, in contrast to other countries such as the U.S., the statutory audit market (and the regulation and public oversight thereof) in the Netherlands entails the entire audit market including audits of private companies. More specifically, private companies in the Netherlands constitute the majority of the Dutch market for audit services: approximately 95 percent in number of audits and 83 percent in audit fees. While most U.S. auditing research is focused on listed companies, and therefore larger audit firms, the setting used in this dissertation also allows studying the combination of publicly listed and private companies, and therefore large and small audit firms.

\subsection{Implications and Future Research}

The findings of this dissertation haveimplications for audit firms and auditors, companies hiring auditors, investors, public oversight bodies, and regulators, and provide insights into future research opportunities.

The conclusion of the first study presented in Chapter 2 is that the public oversight body is able to differentiate audit quality, in contrast with the prior peer review system. This positively supports regulators' decisions to replace peer review systems with independent public oversight. Companies hiring auditors and investors relying on auditors' opinions may also benefit from knowing the reliability of the public oversight body's assessment of audit firm quality by choosing higher quality auditors and thereby pressuring lower quality auditors to improve themselves. In light of worldwide discussions on the effectiveness and mutual recognition of audit oversight systems, insights from this study may benefit public oversight bodies across the world in further shaping their oversight systems. The additional findings in this study regarding the types of deficiencies in audit firms that are most able to distinguish audit quality provide useful information for audit firms to improve those areas and strengthen their overall quality control.

The second part of the conclusion, however, states that neither the peer review system nor the public oversight body appear to bring about improvement in audit quality, at least in the short term. A possible explanation could be that audit firm-specific inspection reports were not publicly disclosed until2014. Thelack of quality improvement should be of primary concern to stakeholders involved and calls for further research on 
its causes. For example by examining audit quality changes in a setting where there is a change in disclosure policy. More generally, future research could look into the effectiveness of public oversight in improving audit quality over a longer time period, in an international context, and by employing different research methodologies (e.g., experiment, field study).

The results of the second study presented in Chapter 3 show that business relationships are consistently associated with higher audit fees and, particularly in those situations where the business relationship coincides with high non-audit fees relative to audit fees, with higher earnings quality. These findings may be of interest to the investors who are ultimately paying for a more expensive audit. Although the findings suggest that audit firms and auditors are complying with independence regulations requiring them to increase engagement effort to safeguard audit quality, it is not entirely certain that the auditor's independence is not at all impaired by the business relationship. Future research, either by academics or by public oversight bodies in course of their inspections, could elaborate on this study by examining business relationships for specific circumstances in which increased professional skepticism, and therefore strict objectivity and independence, is of utmost importance, such as the need for restatements or goingconcern issues. Furthermore, future research may attempt to disentangle the different causes for audit fees to change, such as audit effort, risk premiums, or audit efficiency, and to find additional control variables to alleviate the potential endogeneity problems identified in the current study. Future research could also expand the literature on auditor independence by exploring the other types of independence threats covered by the Code of Ethics, such as financial interests, family and personal relationships, gifts and hospitality, and actual or threatened litigation.

Although the results of the third study presented in Chapter 4 show that various audit firm governance characteristics are capturing aspects of audit firm quality, albeit to a different extent, the extensive descriptive analyses provide useful information for the ongoing debates about audit quality indicators. Audit firms, regulators, and the investors ultimately requiring increased audit firm transparency, will need to continue their collaborative search of consistently reliable measures that adequately provide this transparency. Academics may facilitate this search by conducting research that overcomes the limitations identified in the current study, for instance by employing alternative definitions of audit firm governance characteristics or other audit quality measures. 
Abbott, L. J., K. A. Gunny, and T. C. Zhang. 2013. When the PCAOB Talks, Who Listens? Evidence from Stakeholder Reaction to GAAP-Deficient PCAOB Inspection Reports of Small Auditors. Auditing: A Journal of Practice \& Theory 32 (2):1-31.

Abdel-khalik, A. R., and I. Solomon, eds. 1988. Research Opportunities in Auditing: The Second Decade.: FL: American Accounting Association-Auditing Section.

Abernethy, M. A., and J. U. Stoelwinder. 1995. The Role of Professional Control in the Management of Complex Organizations. Accounting, Organizations and Society 20 (1):1-17.

Advisory Committee on the Auditing Profession (ACAP). 2008. Final Report. Available at: https://www.treasury.gov/about/organizational-structure/offices/ Documents/final-report.pdf.

AFS Act. 2006. Audit Firms Supervision Act (AFS Act) (Wet toezicht accountantsorganisaties). Staatsblad van het Koninkrijk der Nederlanden Jaargang 2006 (70).

Anantharaman, D. 2012. Comparing self-regulation and statutory regulation: Evidence from the accounting profession. Accounting, Organizations and Society 37 (2):5577.

Aobdia, D. 2015. The Validity of Publicly Available Measures of Audit Quality: Evidence from the PCAOB Inspection Data. Working paper: Public Company Accounting Oversight Board, and Northwestern University. Available at SSRN: http://ssrn. com/abstract $=2629305$.

Ashbaugh, H., R. LaFond, and B. W. Mayhew. 2003. Do Nonaudit Services Compromise Auditor Independence? Further Evidence. The Accounting Review 78 (3):611-639.

Autoriteit Financiële Markten [Netherlands Authority for the Financial Markets] (AFM). 2010. Report on general findings regarding audit quality and quality control monitoring. Amsterdam: AFM.

_ 2011. Incentives for Audit Quality - An exploratory review. Amsterdam: AFM.

_.2013a. Report on AFM inspection of the quality of audit and system of quality control and quality monitoring at nine PIE licence holders. Amsterdam: AFM.

- 2013b. Thematic review of non-PIE audit firms. Amsterdam: AFM.

_ 2014. Results of the inspection of the quality of statutory audits at the Big 4 audit firms. Amsterdam: AFM.

Balachandran, B. V., and R. T. S. Ramakrishnan. 1987. A Theory of Audit Partnerships: Audit Firm Size and Fees. Journal of Accounting Research 25 (1):111-126. 
Ball, R. 2013. Accounting Informs Investors and Earnings Management is Rife: Two Questionable Beliefs: American Accounting Association, 847-853.

Beasley, M. S., J. V. Carcello, D. R. Hermanson, and P. D. Lapides. 2000. Fraudulent Financial Reporting: Consideration of Industry Traits and Corporate Governance Mechanisms. Accounting Horizons 14 (4):441-454.

Beattie, V., and S. Fearnley. 2002. Auditor Independence and Non-Audit Services: A Literature Review. London: Institute of Chartered Accountants in England and Wales.

Becker, C. L., M. L. DeFond, J. Jiambalvo, and K. R. Subramanyam. 1998. The Effect of Audit Quality on Earnings Management. Contemporary Accounting Research 15 (1):1-24.

Bedard, J. C., N. Cannon, and A. Schnader. 2015. PCAOB Oversight in the Broker-Dealer Industry: Regulatory Shock and Auditor Realignment. Working paper: Bentley University and Texas State University.

Bedard, J. C., D. R. Deis, M. B. Curtis, and J. G. Jenkins. 2008. Risk Monitoring and Control in Audit Firms: A Research Synthesis. Auditing: A Journal of Practice \& Theory 27 (1):187-218.

Bedard, J. C., K. M. Johnstone, and E. F. Smith. 2010. Audit Quality Indicators: A Status Update on Possible Public Disclosures and Insights from Audit Practice. Current Issues in Auditing 4 (1):C12-C19.

Bell, T. B., M. Causholli, and W. R. Knechel. 2015. Audit Firm Tenure, Non-audit Services, and Internal Assessments of Audit Quality. Journal of Accounting Research 53 (3):461-509.

Boone, C., V. Bröcheler, and G. R. Caroll. 2000. Custom service: Application and tests of resourcepartitioning theory among Dutch auditing firms from 1896 to 1992. Organization Studies 21:355-381.

Boone, J. P., I. K. Khurana, and K. K. Raman. 2010. Do the Big 4 and the Second-tier firms provide audits of similar quality? Journal of Accounting and Public Policy 29 (4):330352.

Bröcheler, V., S. Maijoor, and A. v. Witteloostuijn. 2004. Auditor human capital and audit firm survival: The Dutch audit industry in 1930-1992. Accounting, Organizations and Society 29:627-646.

Brown, L. D., and M. L. Caylor. 2004. Corporate Governance and Firm Performance. Available at SSRN: http://ssrn.com/abstract=586423.

Buchheit, S., and W. L. Buslepp. 2014. Workload Ratios as Audit Quality Indicators: An Empirical Analysis using PCAOB Headcount Disclosures. Working paper: University of Alabama and Texas Tech University.

Caramanis, C., and C. Lennox. 2008. Audit effort and earnings management. Journal of Accounting and Economics 45 (1):116-138.

Carcello, J. V., C. Hollingsworth, and S. A. Mastrolia. 2011. The effect of PCAOB inspections on Big 4 audit quality. Research in Accounting Regulation 23 (2):85-96. 
Carey, P., and R. Simnett. 2006. Audit Partner Tenure and Audit Quality. The Accounting Review 81 (3):653-676.

Casterella, J. R., K. L. Jensen, and W. R. Knechel. 2009. Is Self-Regulated Peer Review Effective at Signaling Audit Quality? The Accounting Review 84 (3):713-735.

_ 2010. Litigation Risk and Audit Firm Characteristics. Auditing: A Journal of Practice \& Theory 29 (2):71-82.

Causholli, M., and W. R. Knechel. 2012. An Examination of the Credence Attributes of an Audit. Accounting Horizons 26 (4):631-656.

Chi, W., H. Huang, Y. Liao, and H. Xie. 2009. Mandatory Audit Partner Rotation, Audit Quality, and Market Perception: Evidence from Taiwan. Contemporary Accounting Research 26 (2):359-391.

Christensen, B., K. W. Smith, and D. Wang. 2015a. The Effect of Audit Regulation on Small Audit Firm Mergers and Audit Quality. Working paper: The University of Missouri-Columbia, and Texas A\&M University.

Christensen, B. E., S. M. Glover, T. C. Omer, and M. K. Shelley. 2015b. Understanding Audit Quality: Insights from Audit Professionals and Investors. Contemporary Accounting Research.

Chung, H., and S. Kallapur. 2003. Client Importance, Nonaudit Services, and Abnormal Accruals. The Accounting Review 78 (4):931-955.

Church, B. K., J. G. Jenkins, S. A. McCracken, P. B. Roush, and J. D. Stanley. 2015. Auditor Independence in Fact: Research, Regulatory, and Practice Implications Drawn from Experimental and Archival Research. Accounting Horizons 29 (1):217-238.

Covaleski, M. A., M. W. Dirsmith, J. B. Heian, and S. Samuel. 1998. The Calculated and the Avowed: Techniques of Discipline and Struggles over Identity in Big Six Public Accounting Firms. Administrative Science Quarterly 43 (2):293-327.

Craswell, A. T., and J. R. Francis. 1999. Pricing Initial Audit Engagements: A Test of Competing Theories. The Accounting Review 74 (2):201-216.

Craswell, A. T., J. R. Francis, and S. L. Taylor. 1995. Auditor brand name reputations and industry specializations. Journal of Accounting and Economics 20 (3):297-322.

Dart, E., and R. Chandler. 2012. Client employment of previous auditors: shareholders' views on auditor independence. Accounting \& Business Research 43 (3):205-224.

De Fuentes, B., I. Cristina, M. Muñoz, and M. C. Pucheta Martinez. 2010. Disciplinary Sanctions and Audit Quality: Empirical Evidence from an External Oversight System. Available at SSRN: http://ssrn.com/abstract=1636730.

DeAngelo, L. E. 1981a. Auditor independence, 'low balling', and disclosure regulation. Journal of Accounting and Economics 3 (2):113-127.

_.1981b. Auditor size and audit quality. Journal of Accounting and Economics 3 (3):183-199.

Dechow, P., W. Ge, and C. Schrand. 2010. Understanding earnings quality: A review of the proxies, their determinants and their consequences. Journal of Accounting and Economics 50 (2-3):344-401. 
Dechow, P. M., and I. D. Dichev. 2002. The Quality of Accruals and Earnings: The Role of Accrual Estimation Errors. The Accounting Review 77 (4):35-59.

Dechow, P. M., R. G. Sloan, and A. P. Sweeney. 1995. Detecting Earnings Management. The Accounting Review 70 (2):193-225.

Dee, C. C., A. Lulseged, and T. Zhang. 2011. Client Stock Market Reaction to PCAOB Sanctions Against a Big 4 Auditor. Contemporary Accounting Research 28 (1):263-291.

DeFond, M. L. 2010. How should the auditors be audited? Comparing the PCAOB Inspections with the AICPA Peer Reviews. Journal of Accounting and Economics 49 $(1 / 2): 104-108$.

DeFond, M. L., and J. Jiambalvo. 1994. Debt covenant violation and manipulation of accruals. Journal of Accounting and Economics 17 (1/2):145-176.

DeFond, M. L., and C. Lennox. 2011. The effect of SOX on small auditor exits and audit quality. Journal of Accounting and Economics 52 (1):21-40.

DeFond, M. L., and C. W. Park. 2001. The Reversal of Abnormal Accruals and the Market Valuation of Earnings Surprises. The Accounting Review 76 (3):375-404.

DeFond, M. L., K. Raghunandan, and K. R. Subramanyam. 2002. Do Non-Audit Service Fees Impair Auditor Independence? Evidence from Going Concern Audit Opinions. Journal of Accounting Research 40 (4):1247-1274.

DeFond, M. L., and J. Zhang. 2014. A review of archival auditing research. Journal of Accounting and Economics 58 (2-3):275-326.

Deis, D. R., Jr., and G. Giroux. 1996. The effect of auditor changes on audit fees, audit hours, and audit quality. Journal of Accounting and Public Policy 15 (1):55-76.

Deis, D. R., Jr., and G. A. Giroux. 1992. Determinants of Audit Quality in the Public Sector. The Accounting Review 67 (3):462-479.

Deumes, R., C. Schelleman, H. V. Bauwhede, and A. Vanstraelen. 2012. Audit Firm Governance: Do Transparency Reports Reveal Audit Quality? Auditing: A Journal of Practice \& Theory 31 (4):193-214.

Ditillo, A. 2004. Dealing with uncertainty in knowledge-intensive firms: the role of management control systems as knowledge integration mechanisms. Accounting, Organizations and Society 29 (3-4):401-421.

Doogar, R., P. Sivadasan, and I. Solomon. 2015. Audit fee residuals: Costs or rents? Review of Accounting Studies:1-40.

Elliott, R. K. 1998. Assurance Services and the Audit Heritage. Auditing: A Journal of Practice \& Theory 17:1-7.

Emby, C., and M. Favere-Marchesi. 2010. Review Partners and Engagement Partners: The Interaction Process in Engagement Quality Review. Auditing: A Journal of Practice \& Theory 29 (2):215-232.

Epps, K. K., and J. W. F. Messier. 2007a. Engagement Quality Reviews: A Comparison of Audit Firm Practices. Auditing: A Journal of Practice \& Theory 26 (2):167-181. . 2007b. Improving the Effectiveness of Engagement Quality Review. Working paper: Kennesaw State University and Georgia State University. 
Eshleman, J. D., and P. Guo. 2014a. Abnormal Audit Fees and Audit Quality: The Importance of Considering Managerial Incentives in Tests of Earnings Management. Auditing: A Journal of Practice \& Theory 33 (1):117-138.

. 2014b. Do Big 4 Auditors Provide Higher Audit Quality after Controlling for the Endogenous Choice of Auditor? Auditing: A Journal of Practice \& Theory 33 (4):197219.

Ettredge, M., and R. Greenberg. 1990. Determinants of Fee Cutting on Initial Audit Engagements. Journal of Accounting Research 28 (1):198-210.

European Union. 2006. Directive 2006/43/EC of the European Parliament and of the Council of 17 May 2006 on statutory audits of annual accounts and consolidated accounts.

Fédération des Experts Comptables Européens (FEE). 2006. Quality Assurance Arrangements Across Europe.

_ 2015. Overview of Audit Quality Indicators Initiatives. Available at: http://www. fee.be/images/publications/auditing/1511_Overview_of_Audit_Quality_ Indicators_Initiatives.pdf.

Financial Reporting Council (FRC). 2008. The Statutory Auditors (Transparency) Instrument 2008. London, UK: Financial Reporting Council.

Firth, M., P. L. L. Mo, and R. M. K. Wong. 2012. Auditors' Organizational Form, Legal Liability, and Reporting Conservatism: Evidence from China. Contemporary Accounting Research 29 (1):57-93.

Fogarty, T. J. 1996. The imagery and reality of peer review in the U.S.: Insights from institutional theory. Accounting, Organizations and Society 21 (2/3):243-267.

Francis, J. R. 1984. The effect of audit firm size on audit prices: A study of the Australian Market. Journal of Accounting and Economics 6 (2):133-151.

_ 2004. What do we know about audit quality? The British Accounting Review 36 (4):345-368.

_ 2011. A Framework for Understanding and Researching Audit Quality. Auditing: A Journal of Practice \& Theory 30 (2):125-152.

Francis, J. R., and J. Krishnan. 1999. Accounting Accruals and Auditor Reporting Conservatism. Contemporary Accounting Research 16 (1):135-165.

Francis, J. R., and P. N. Michas. 2013. The Contagion Effect of Low-Quality Audits. The Accounting Review 88 (2):521-552.

Francis, J. R., P. N. Michas, and S. E. Seavey. 2013. Does Audit Market Concentration Harm the Quality of Audited Earnings? Evidence from Audit Markets in 42 Countries. Contemporary Accounting Research 30 (1):325-355.

Francis, J. R., C. Richard, and A. Vanstraelen. 2009. Assessing France's Joint Audit Requirement: Are Two Heads Better than One? Auditing: A Journal of Practice \& Theory 28 (2):35-63.

Francis, J. R., and D. T. Simon. 1987. A Test of Audit Pricing in the Small-Client Segment of the U.S. Audit Market. The Accounting Review 62 (1):145-157. 
Francis, J. R., and D. Wang. 2008. The Joint Effect of Investor Protection and Big 4 Audits on Earnings Quality around the World. Contemporary Accounting Research 25 (1):157-191.

Fu, Y., E. Carson, and R. Simnett. 2015. Transparency report disclosure by Australian audit firms and opportunities for research. Managerial AuditingJournal30 (8/9):870910.

Future Accountancy Profession Working Group. 2014. In the Public Interest - Measures to Improve the Quality and Independence of the Audit in the Netherlands Available at: https://www.accountant.nl/globalassets/accountant.nl/toekomstaccountantsberoep/in_the_public_interest.pdf.

Gaynor, L. M., A. S. Kelton, M. Mercer, and T. L. Yohn. 2015. Understanding the Relationship between Financial Reporting Quality and Audit Quality. Working Paper: University of South Florida, Wake Forest University, DePaul University, and Indiana University.

Geiger, M. A., C. Lennox, and D. North. 2008. The hiring of accounting and finance officers from audit firms: how did the market react? Review of Accounting Studies 13 (1):55-86.

Geiger, M. A., D. S. North, and B. T. O'Connell. 2005. The Auditor-to-Client Revolving Door and Earnings Management. Journal of Accounting, Auditing \& Finance 20 (1):1-26.

Ghosh, A., and R. Pawlewicz. 2009. The Impact of Regulation on Auditor Fees: Evidence from the Sarbanes-Oxley Act. Auditing: A Journal of Practice \& Theory 28 (2):171197.

Gramling, A. A., J. G. Jenkins, and M. H. Taylor. 2010. Policy and Research Implications of Evolving Independence Rules for Public Company Auditors. Accounting Horizons 24 (4):547-566.

Gramling, A. A., J. Krishnan, and Y. Zhang. 2011. Are PCAOB-Identified Audit Deficiencies Associated with a Change in Reporting Decisions of Triennially Inspected Audit Firms? Auditing: A Journal of Practice \& Theory 30 (3):59-79.

Greenwood, R., and L. Empson. 2003. The Professional Partnership: Relic or Exemplary Form of Governance? Organization Studies 24 (6):909-933.

Greenwood, R., C. R. Hinings, and J. Brown. 1990. P2-Form strategic management: corporate practices in professional partnerships. Academy of Management Journal $33(4): 725-755$.

Gregory, A., and P. Collier. 1996. Audit fees and auditor change: An investigation of the persistence of fee reduction by type of change. Journal of Business Finance \& Accounting 23 (1):13-28.

Griffin, P. A., D. H. Lont, and Y. Sun. 2010. Agency problems and audit fees: further tests of the free cash flow hypothesis. Accounting \& Finance 50 (2):321-350.

Gul, F. A., B. Jaggi, and G. Krishnan. 2007. Auditor Independence: Evidence on the Joint Effects of Auditor Tenure and Non-Audit Fees. Auditing: A Journal of Practice \& Theory 26 (2):117-142. 
Gunny, K. A., and T. C. Zhang. 2013. PCAOB inspection reports and audit quality. Journal of Accounting and Public Policy 32 (2):136-160.

Hair, J. F., W. C. Black, B. J. Babin, R. E. Anderson, and R. L. Tatham. 2006. Multivariate Data Analysis Sixth Edition. New Jersey: Pearson Education.

Hay, D. C., W. R. Knechel, and N. Wong. 2006. Audit Fees: A Meta-analysis of the Effect of Supply and Demand Attributes. Contemporary Accounting Research 23 (1):141191.

Heckman, J. J. 1979. Sample Selection Bias as a Specification Error. Econometrica 47 (1):153-161.

Hermanson, D. R., R. W. Houston, and J. C. Rice. 2007. PCAOB Inspections of Smaller CPA Firms: Initial Evidence from Inspection Reports. Accounting Horizons 21 (2):137-152.

Hilary, G., and C. Lennox. 2005. The credibility of self-regulation: Evidence from the accounting profession's peer review program. Journal of Accounting and Economics 40 (1-3):211-229.

Hopwood, A. 1976. Accounting and Human Behavior: Englewood Cliffs, NJ: Prentice Hall.

Hossain, M., S. Mitra, Z. Rezaee, and B. Sarath. 2011. Corporate Governance and Earnings Management in the Pre-and Post-Sarbanes-Oxley Act Regimes: Evidence from Implicated Option Backdating Firms. Journal of Accounting, Auditing \& Finance 26 (2):279-315.

Hribar, P., T. Kravet, and R. Wilson. 2014. A new measure of accounting quality. Review of Accounting Studies 19 (1):506-538.

Hribar, P., and D. C. Nichols. 2007. The Use of Unsigned Earnings Quality Measures in Tests of Earnings Management. Journal of Accounting Research 45 (5):1017-1053.

Institute of Chartered Accountants in England and Wales and Financial Reporting Council (ICAEW/FRC). 2010. The Audit Firm Governance Code. London: ICAEW.

International Auditing and Assurance Standards Board (IAASB). 2009a. International Standard on Auditing 220 Quality Control for an Audit of Financial Statements Available at: http://www.ifac.org/system/files/downloads/a010-2010-iaasbhandbook-isa-220.pdf.

. 2009b. International Standard on Quality Control 1: Quality Control for Firms that Perform Audits and Reviews of Financial Statements, and Other Assurance and Related Service Engagements (ISQC 1). NY: IAASB.

. 2009c. International Standard on Quality Control 1: Quality Control for Firms that Perform Audits and Reviews of Financial Statements, and Other Assurance and Related Services Engagements. Available at: http://www.ifac.org/system/ files/downloads/a007-2010-iaasb-handbook-isqc-1.pdf.

International Ethics Standards Board for Accountants (IESBA). 2013. Handbook of the Code of Ethics for Professional Accountants. New York: International Federation of Accountants. 
Jenkins, J. G., D. R. Deis, J. C. Bedard, and M. B. Curtis. 2008. Accounting Firm Culture and Governance: A Research Synthesis. Behavioral Research in Accounting 20 (1):4574.

Johnstone, K. M., and J. C. Bedard. 2001. Engagement Planning, Bid Pricing, and Client Response in the Market for Initial Attest Engagements. The Accounting Review 76 (2):199-220.

_ 2003. Risk Management in Client Acceptance Decisions. The Accounting Review 78 (4):1003-1025.

Johnstone, K. M., M. H. Sutton, and T. D. Warfield. 2001. Antecedents and Consequences on Independence Risk: Framework for Analysis. Accounting Horizons 15 (1):1-18.

Jones, J. J. 1991. Earnings Management During Import Relief Investigations. Journal of Accounting Research 29 (2):193-228.

Kang, F., M. Farag, R. Hurt, and C. Wyrick. 2014. The association between PCAOBidentified audit deficiencies and small audit firms' characteristics: Evidence from PCAOB inspection reports. Managerial Auditing Journal 29 (8):717-735.

Klapper, L. F., and I. Love. 2004. Corporate governance, investor protection, and performance in emerging markets. Journal of Corporate Finance 10 (5):703-728.

Klein, A. 1998. Firm Performance and Board Committee Structure. Journal of Law \& Economics 41 (1):275-303.

_ 2002. Audit committee, board of director characteristics, and earnings management. Journal of Accounting and Economics 33 (3):375-400.

Knechel, W. R. 2001. Auditing Assurance \& Risk: 2nd edition. South-Western College Publishing.

Knechel, W. R., G. V. Krishnan, M. Pevzner, L. B. Shefchik, and U. K. Velury. 2013. Audit Quality: Insights from the Academic Literature. Auditing: A Journal of Practice \& Theory 32:385-421.

Knechel, W. R., and D. S. Sharma. 2012. Auditor-Provided Nonaudit Services and Audit Effectiveness and Efficiency: Evidence from Pre- and Post-SOX Audit Report Lags. Auditing: A Journal of Practice \& Theory 31 (4):85-114.

Kothari, S. P., A. J. Leone, and C. E. Wasley. 2005. Performance matched discretionary accrual measures. Journal of Accounting and Economics 39 (1):163-197.

Langendijk, H. 1997. The market for audit services in the Netherlands. European Accounting Review 6 (2):253-264.

Lavin, D. 1976. Perceptions of the Independence of the Auditor. The Accounting Review $51(1): 41-50$.

Lawrence, A., M. Minutti-Meza, and P. Zhang. 2011. Can Big 4 versus Non-Big 4 Differences in Audit-Quality Proxies Be Attributed to Client Characteristics? The Accounting Review 86 (1):259-286.

Lee, J. E., and G. S. Bae. 2012. How Do Audit Firm Quality Indicators Relate to Engagement-Level Audit Quality? Working paper: Hongik University and Korea University. 
Lennox, C. 2005. Audit quality and executive officers' affiliations with CPA firms. Journal of Accounting and Economics 39 (2):201-231.

Lennox, C., and B. Li. 2012. The consequences of protecting audit partners' personal assets from the threat of liability. Journal of Accounting and Economics 54 (2-3):154173.

Lennox, C., and J. Pittman. 2010a. Auditing the auditors: Evidence on the recent reforms to the external monitoring of audit firms. Journal of Accounting and Economics 49 (1/2):84-103.

Lennox, C., and J. A. Pittman. 2010b. Big Five Audits and Accounting Fraud. Contemporary Accounting Research 27 (1):209-247.

Lennox, C. S., J. R. Francis, and Z. Wang. 2012. Selection Models in Accounting Research. The Accounting Review 87 (2):589-616.

Lennox, C. S., and J. A. Pittman. 2011. Voluntary Audits versus Mandatory Audits. The Accounting Review 86 (5):1655-1678.

Lennox, C. S., X. Wu, and T. Zhang. 2014. Does Mandatory Rotation of Audit Partners Improve Audit Quality? The Accounting Review 89 (5):1775-1803.

Lobo, G. J., and Y. Zhao. 2013. Relation between Audit Effort and Financial Report Misstatements: Evidence from Quarterly and Annual Restatements. The Accounting Review 88 (4):1385-1412.

Luehlfing, M. S., P. A. Copley, and R. A. Shockley. 1995. An Examination of the Relationship Between Audit-Related Risk and the second Partner Review. Journal of Accounting, Auditing \& Finance 10 (1):43-50.

Maijoor, S., and A. Vanstraelen. 2012. "Research Opportunities in Auditing in the EU," Revisited. Auditing: A Journal of Practice \& Theory 31 (1):115-126.

Martin, R. D. 2013. Audit Quality Indicators: Audit Practice Meets Audit Research. Current Issues in Auditing 7 (2):A17-A23.

Matsumura, E. M., and R. R. Tucker. 1995. Second Partner Review: An Analytical Model. Journal of Accounting, Auditing \& Finance 10 (1):173-200.

McNair, C. J. 1991. Proper Compromises: The Management Control Dilemma in Public Accounting and its Impact on Auditor Behavior. Accounting, Organizations and Society 16 (7):635-653.

Menon, K., and D. D. Williams. 2004. Former Audit Partners and Abnormal Accruals. The Accounting Review 79 (4):1094-1118.

Morris, T., and L. Empson. 1998. Organisation and expertise: An exploration of knowledge bases and the management of accounting and consulting firms. Accounting, Organizations and Society 23 (5/6):609-624.

Mueller, G., H. Gernon, and G. Meek. 1994. Accounting: An International Perspective. Boston, MA: Irwin McGraw-Hill.

Nagy, A. L. 2014. PCAOB Quality Control Inspection Reports and Auditor Reputation. Auditing: A Journal of Practice \& Theory 33 (3):87-104.

Niu, F. F. 2006. Corporate governance and the quality of accounting earnings: a Canadian perspective. International Journal of Managerial Finance 2 (4):302-327. 
Nobes, C. W. 1998. Towards a general model of the reasons for international differences in financial reporting. Abacus 34:162-187.

Offermanns, M., and A. Vanstraelen. 2014. Oversight and Inspection of Auditing. In The Routledge Companion to Auditing, edited by D. Hay, W. R. Knechel and M. Willekens: Routledge.

Otley, D. T., and B. J. Pierce. 1996. The Operation of Control Systems in Large Audit Firms. Auditing: A Journal of Practice \& Theory 15 (2):65-84.

Palmrose, Z.-V. 1986a. Audit Fees and Auditor Size: Further Evidence. Journal of Accounting Research 24 (1):97-110.

_ 1986b. The Effect of Nonaudit Services on the Pricing of Audit Services: Further Evidence. Journal of Accounting Research 24 (2):405-411.

_ 1989. The Relation of Audit Contract Type to Audit Fees and Hours. The Accounting Review 64 (3):488-499.

Pany, K., and P. M. J. Reckers. 1980. The Effect of Gifts, Discounts, and Client Size on Perceived Auditor Independence. The Accounting Review 55 (1):50-61.

Peltzman, S. 1976. Toward a More General Theory of Regulation. Journal of Law and Economics 19 (2):211-240.

Pierce, B., and B. Sweeney. 2005. Management control in audit firms-Partners' perspectives. Management Accounting Research 16:340-370.

Public Company Accounting Oversight Board (PCAOB). 2013. Standing Advisory Group Meeting Discussion - Audit Quality Indicators May 15-16, 2013. Washington.

_ 2015. Statement on Concept Release on Audit Quality Indicators. Washington.

Read, W. J., D. V. Rama, and K. Raghunandan. 2004. Local and Regional Audit Firms and the Market for SEC Audits. Accounting Horizons 18 (4):241-254.

Reynolds, J. K., and J. R. Francis. 2001. Does size matter? The influence of large clients on office-level auditor reporting decisions. Journal of Accounting and Economics 30:375-400.

Rosenbaum, P. R., and D. B. Rubin. 1983. The Central Role of the Propensity Score in Observational Studies for Causal Effects. Biometrika 70 (1):41-55.

Roybark, H. M. 2009. An Analysis of Audit Deficiencies Based on Section 104 Inspection Reports Issued by the PCAOB during 2004-2007. Journal of Accounting, Ethics \& Public Policy 10 (1):1-81.

Schelleman, C., and W. R. Knechel. 2010. Short-Term Accruals and the Pricing and Production of Audit Services. Auditing: A Journal of Practice \& Theory 29 (1):221250.

Schmidt, J. J. 2012. Perceived Auditor Independence and Audit Litigation: The Role of Nonaudit Services Fees. The Accounting Review 87 (3):1033-1065.

Seetharaman, A., F. A. Gul, and S. G. Lynn. 2002. Litigation risk and audit fees: evidence from UK firms cross-listed on US markets. Journal of Accounting and Economics 33 (1):91-115. 
Sharma, D. 2014. Non Audit Services and Auditor Independence. In The Routledge Companion to Auditing, edited by D. Hay, W. R. Knechel and M. Willekens: Routledge.

Simon, D. T., and J. R. Francis. 1988. The Effects of Auditor Change on Audit Fees: Tests of Price Cutting and Price Recovery. The Accounting Review 63 (2):255-269.

Simunic, D. A. 1980. The Pricing of Audit Services: Theory and Evidence. Journal of Accounting Research 18 (1):161-190.

- 1984. Auditing, Consulting, and Auditor Independence. Journal of Accounting Research 22 (2):679-702.

Simunic, D. A., and M. T. Stein. 1996. The Impact of Litigation Risk on Audit Pricing: A Review of the Economics and the Evidence. Auditing: A Journal of Practice \& Theory 15 (2):119-134.

Stigler, G. J. 1971. The Theory of Economic Regulation. The Bell Journal of Economics and Management Science 2 (1):3-21.

Sweeney, B., and B. Pierce. 2005. Management control in audit firms: A qualitative examination. Accounting, Auditing \& Accountability Journal 17 (5):779-812.

- 2006. Good hours, bad hours and auditors' defence mechanisms in audit firms. Accounting, Auditing \& Accountability Journal 19 (6):858-892.

Tan, H.-T. 1995. Effects of Expectations, Prior Involvement, and Review Awareness on Memory for Audit Evidence and Judgment. Journal of Accounting Research 33 (1):113-135.

Technical Committee of the International Organization of Securities Commissions (IOSCO). 2009. Transparency of Firms that Audit Public Companies - Consultation Report. Madrid: IOSCO.

Teoh, S. H., T. J. Wong, and G. R. Rao. 1998. Are Accruals during Initial Public Offerings Opportunistic? Review of Accounting Studies 3 (1):175-208.

Tepalagul, N., and L. Lin. 2015. Auditor Independence and Audit Quality: A Literature Review. Journal of Accounting, Auditing \& Finance 30 (1):101-121.

Tucker, R. R., and E. M. Matsumura. 1997. Second-Partner Review: An Experimental Economics Investigation. Auditing: A Journal of Practice \& Theory 16 (1):79-98.

U.S. House of Representatives. 2002. The Sarbanes-Oxley Act of 2002. Public Law 107-204 [H. R. 3763]. Washington, D.C.: Government Printing Office.

Van de Poel, K., and A. Vanstraelen. 2011. Management Reporting on Internal Control and Accruals Quality: Insights from a "Comply-or-Explain" Internal Control Regime. Auditing: A Journal of Practice \& Theory 30 (3):181-209.

Van Lent, L. 1999. The Economics of an Audit Firm: The Benefits of Partnership Governance. The British Accounting Review 31 (2):225-254.

Vander Bauwhede, H. 2009. On the relation between corporate governance compliance and operating performance. Accounting \& Business Research 39 (5):497-513.

Warfield, T. D., J. J. Wild, and K. L. Wild. 1995. Managerial ownership, accounting choices, and informativeness of earnings. Journal of Accounting and Economics 20 (1):61-91. 
Watkins, A. L., W. Hillison, and S. E. Morecroft. 2004. Audit Quality: A Synthesis of Theory and Empirical Evidence. Journal of Accounting Literature 23:153-193.

Watts, R. L., and J. L. Zimmerman. 1983. Agency Problems, Auditing, and the Theory of the Firm: Some Evidence. Journal of Law \& Economics 26 (3):613-633.

. 1990. Positive Accounting Theory: A Ten Year Perspective. The Accounting Review 65 (1):131-156.

White, H. 1980. A Heteroskedasticity-Consistent Covariance Matrix Estimator and a Direct Test for Heteroskedasticity. Econometrica 48 (4):817-838.

Wright, C. N., and Q. Booker. 2010. The effects of a cooling-off period on perceived independence of external auditors: A study in the nonpublic regulatory environment. Research in Accounting Regulation 22 (1):47-51.

Young, S. 1999. Systematic Measurement Error in the Estimation of Discretionary Accruals: An Evaluation of Alternative Modelling Procedures. Journal of Business Finance \& Accounting 26 (7/8):833-862. 
This dissertation investigates how the quality of auditing of financial statements relates to the regulatory context in which audits are performed. In Chapter 1 the added value of (high quality) auditing for the general public is explained. Auditing is a professional service delivered by experts in which they provide assurance about the reliability of the information contained in the financial statements prepared in accordance with generally accepted accounting principles (Knechel 2001; Knechel et al. 2013). Many stakeholders are basing economic decisions on information in companies' financial statements. Those users of financial statements, which include capital providers such as shareholders and creditors, and other stakeholders such as suppliers, customers and employees, need those statements to provide reliable information regarding the company's financial position. Usually, they are not in a position to evaluate the reliability of the financial statements, because they do not have access to the underlying data, they lack the skills to do so, and it would be too costly. Therefore, they have an information disadvantage in comparison to the company's management. The interests of company's management, which is responsible for providing the information, and the users of that information, may not be aligned. In fact, it is widely agreed that these interests are often conflicting: while users of financial statements require relevant and reliable information, company's management may have incentives, for instance personal bonuses, to present the information more favorably. Auditors are the independent professionals hired to provide a competent and objective opinion on the reliability of the information. In doing so, they improve the quality of that information and reduce the information disadvantage of the users of financial statements. Auditors thus operate primarily in the public interest.

The quality of the audits performed determines the level of assurance and added value provided to the public in general, and users of financials statements in particular. Since auditors are operating in a system with incentives that may negatively influence the quality of the audits they perform, there is a need for professional standards and regulation to ensure a constant and adequate level of auditing. A number of large audit failures and accounting scandals in the early 2000s (e.g., Enron, WorldCom, Xerox, Ahold, and Parmalat) have severely undermined public confidence in auditors and their reports. Worldwide, regulators have responded by increasing their regulatory focus on audit firms in the course of the last fifteen years. Three of those regulatory topics are at the heart of this dissertation: the introduction of independent public oversight, the 
strengthening of auditor independence, and the development of audit quality indicators to increase audit firm transparency.

The purpose of this dissertation is to empirically assess how these regulatory topics (i.e., public oversight, auditor independence, and audit quality indicators) relate to audit quality. Are they informative about audit quality and do they improve audit quality? Besides contributing to the existing literature on audit quality by exploiting the unique access to proprietary data on audit firms from the Dutch public oversight body, the empirical assessment of these relationships also has practical importance and implications for audit firms and auditors, companies hiring auditors, investors, public oversight bodies, and regulators (also described in Chapter 5).

The first study, presented in Chapter 2, examines the relationship between public oversight and audit quality. After a number of high-profile corporate failures, regulators started to believe that the self-regulatory peer review system was no longer adequate and appropriately functioning. Independent public oversight was proposed instead as an alternative way of organizing audit oversight with the goal to restore confidence in and safeguard the public function of the auditing profession and the quality of its work. This study examines the effectiveness of public oversight in the Netherlands by testing whether (a) the public oversight body can differentiate audit quality in its first-time inspection round, and (b) audit quality improves after the first-time inspection round. The conclusion of this study is that the public oversight body is able to differentiate audit quality, in contrast with the prior peer review system. This positively supports regulators' decisions to replace peer review systems with independent public oversight. Companies hiring auditors and investors relying on auditors' opinion may also benefit from knowing the reliability of public oversight body's assessment of audit firm quality by choosing higher quality auditors and thereby pressuring lower quality auditors to improve themselves. In light of worldwide discussions on the effectiveness and mutual recognition of audit oversight systems, insights from this study may benefit public oversight bodies across the world in further shaping their oversight systems. The additional findings in this study regarding the types of deficiencies in audit firms that are most able to distinguish audit quality provide useful information for audit firms to improve those areas and strengthen their overall quality control.

However, the conclusion of this study further states that neither the peer review system nor the public oversight body appear to bring about improvement in audit quality, at least in the short term. A possible explanation could be that audit firm-specific inspection reports were not publicly disclosed in the Netherlands until 2014. The lack of quality improvement should be of primary concern to all stakeholders involved. Auditors and audit firms could question themselves why they were unable to show improvement. Companies hiring auditors, and their audit committees in particular, could incorporate more explicitly the outcomes of public oversight inspections into their hiring decisions, and thereby pressuring lower quality auditors to improve their quality. Similarly, investors could take note of the outcomes of public oversight inspections and start a dialogue, e.g., during shareholders' meetings, with company management about the 
quality of the audit, creating yet another incentive for auditors to increase the quality of their work. Public oversight bodies and regulators could evaluate the effectiveness of their oversight and other regulatory activities and innovate their approaches in order to alter the system of incentives for auditors in such a way that higher quality audits becomes more rewarding.

The second study, presented in Chapter 3, examines the relationship between independence regulation and audit quality. Regulators around the world consider independence regulation as an important instrument to safeguard audit quality. By tightening independence requirements they attempt to improve audit quality and regain public trust in the auditors' reports. Independence requirements deal with specific circumstances and relationships that create or may create threats to independence (e.g. provision of non-assurance services to an audit client, long association of senior personnel with an audit client, employment with an audit client, fees, business relationships, financial interests, family and personal relationships, gifts and hospitality, and actual or threatened litigation). Prior research examined the relationship between a number of these circumstances and relationships on the one hand and audit quality on the other hand. The purpose of this study is to examine one of the previously unaddressed relationships, i.e., business relationships between audit firms and their audit clients. Business relationships arise from commercial relationships or common financial interests between the audit firm and the audit client. This study focuses on business relationships in which the audit firms purchases goods and services from an audit client. It examines the association between the existence of an audit firm-client business relationship and audit quality, inferred from both audit fees and earnings quality.

The results of the second study show that business relationships are consistently associated with higher audit fees and, particularly in those situations where the business relationship coincides with high non-audit fees relative to audit fees, with higher earnings quality. These findings may be of interest to the investors, who are ultimately paying for a more expensive audit. Although the findings suggest that audit firms and auditor are complying with independence regulations requiring them to increase engagement effort to safeguard audit quality, it is not entirely certain that the auditor's independence is not at all impaired by the business relationship. Further assessment of business relationships, either by audit firms themselves or by public oversight bodies in course of their inspections, could elaborate on this study. Questions that remain to be answered are for instance: Why are audit firms procuring goods and services from audit clients when they can also procure them from other companies? Are audit firms indeed spending more audit hours or other resources on audit engagements that coincide with business relationships or are audit fees primarily indicative of risk premiums? Why are audit clients willing to pay higher audit fees when they are also selling goods or services to the audit firm?

The third study, presented in Chapter 4, examines the relationship between audit quality indicators and audit quality. Transparency of audit firms through audit quality indicators is believed to increase market participants' ability to observe audit quality, 
thus enabling differentiation and competition among audit firms on the basis of publicly available data, and providing incentives for firms to increase audit quality. The purpose of this study is to examine whether audit firm governance characteristics are useful audit quality indicators. This is done by testing whether audit firms with stronger governance mechanisms in place are less likely to be confronted with stakeholder dissatisfaction, trigger regulatory attention, or exit the audit market. Audit firm governance is operationalized by constructing organizational variables and quality control system variables. The results provide support that several audit firm governance characteristics are associated with distinct firm-level output measures of audit quality, albeit to a different extent. Further, the extensive descriptive analyses provide useful information for the ongoing public debates about audit quality indicators. Audit firms, regulators, and the investors ultimately requiring increased audit firm transparency, will need to continue their collaborative search of consistently reliable measures that adequately provide this transparency.

In the practical follow-up of all three studies, academics may facilitate stakeholders by conducting research that is aimed at increasing further understanding of the determinants of audit quality or providing support for newly proposed regulatory measures. However, in order to be of value, they will need to incorporate stakeholders' actual underlying questions and concerns into their research hypotheses and make use of data sources that are able to depict reality as closely as possible. Particularly audit firms and public oversight authorities, but possibly also regulators and investors, could increase their collaborative efforts with academics and provide them access to new data sources. In the Netherlands, a first step in this direction was set in October 2015 with the launch of the 'Foundation for Auditing Research'. The eight largest audit firms have affiliated themselves with the foundation by providing access to research data and research subjects and committed to an annual financial grant. This unique collaboration between science and practice is expected to increase the understanding of what determines and improves audit quality. 
Nederlandse Samenvatting

Kwaliteit van Accountantscontrole in een

Gereguleerde Omgeving

Empirische Studies over Publiek Toezicht,

Onafhankelijkheid en Kwaliteitsindicatoren 


\section{Achtergrond en Probleemstelling}

Dit proefschrift onderzoekt hoe de kwaliteit van accountantscontroles van financiële verantwoordingen verband houden met de gereguleerde context waarin die controles worden uitgevoerd. Accountantscontrole is het proces waarin zekerheid wordt verstrekt over de betrouwbaarheid van de informatie in de financiële verantwoording die is opgesteld in overeenstemming met algemeen aanvaarde verslaggevingsstandaarden (Knechel 2001). Accountantscontrole is ook een professionele dienst verleend door deskundigen als antwoord op de economische en gereguleerde vraag ernaar (Knechel et al. 2013). Veel belanghebbenden baseren economische beslissingen op informatie in de financiële verantwoordingen van ondernemingen. Accountants zijn de onafhankelijke professionals die worden ingehuurd om een deskundig en objectief oordeel te vellen over de betrouwbaarheid van die informatie. Zij verhogen daarmee de kwaliteit van die informatie en verkleinen de informatieachterstand van de gebruikers van financiële verantwoordingen. Accountants handelen dus in de eerste plaats in het publieke belang.

Tegelijkertijd functioneren accountants in een systeem met prikkels die de kwaliteit van de accountantscontroles die zij uitvoeren negatief kunnen beïnvloeden (AFM 2014). Ten eerste worden accountants betaald door de ondernemingen waarvan zij de financiële verantwoording controleren, maar waarvan zij onafhankelijk moeten zijn. Ten tweede zijn noch de gebruikers van financiële verantwoordingen, noch de gecontroleerde ondernemingen in staat te beoordelen of de accountant gedurende de controle de juiste beslissingen heeft genomen en dus voldoende kwaliteit heeft geleverd. Ten derde moeten accountants hun eigen zakelijke doelstellingen, zoals groei, efficiëntie enwinstmaximalisatie, inevenwichthoudenmetdegereguleerdekwaliteitsdoelstellingen voor de accountantscontrole. Vanwege deze prikkels die de kwaliteit van accountantscontroles negatief kunnen beïnvloeden, zijn beroepsstandaarden en -regels nodig om een constant en adequaat kwaliteitsniveau van accountantscontroles te waarborgen. Het accountantsvak is een sterk gereguleerd beroep geworden. Internationale wetgevers (bijvoorbeeld de Europese Unie) en regelgevers (bijvoorbeeld de International Auditing and Assurance Standards Board (IAASB) en de International Ethics Standards Board for Accountants (IESBA)) hebben net als nationale wet- en regelgevers (bijvoorbeeld beroepsorganisaties) een breed scala aan eisen opgesteld voor het accountantsberoep. Die eisen zijn enerzijds gericht op individuele accountants (bijvoorbeeld de theoretische en praktijkopleiding, permanente educatie, ethische beroepsregels, inclusief onafhankelijkheidsregels, en controlestandaarden). Anderzijds zijn de eisen gericht op accountantsorganisaties (bijvoorbeeld het opzetten en onderhouden van kwaliteitsbeheersingssystemen en collegiale toetsingen).

Een aantal gevallen van gebrekkige controlekwaliteit en boekhoudschandalen in de vroege jaren 2000 (bijvoorbeeld Enron, WorldCom, Xerox, Ahold en Parmalat) hebbeninsterkematehetpubliekevertrouweninaccountantsenhuncontroleverklaringen ondermijnd. Wereldwijd hebben wet- en regelgevers daarop gereageerd door in de loop van de laatste vijftien jaar hun regelgevende aandacht voor accountantsorganisaties te 
verhogen. Drie van die regelgevende onderwerpen staan centraal in dit proefschrift: de introductie van onafhankelijk publiek toezicht, de versterking van de onafhankelijkheid van de accountant en de ontwikkeling van kwaliteitsindicatoren voor de accountantscontrole om de transparantie van accountantsorganisaties te vergroten.

Een van de meest fundamentele veranderingen in de geschiedenis van het accountantsberoep is dat in veel landen in het eerste decennium van de $21^{\mathrm{e}}$ eeuw onafhankelijke publieke toezichthoudende instanties zijn aangewezen ter vervanging van het door het accountantsberoep zelf gereguleerde systeem van collegiale toetsingen. Deze ontwikkeling in regulering werd ingegeven door spraakmakende faillissementen, waardoor regelgevers gingen geloven dat het systeem van collegiale toetsingen niet langer voldeed en naar behoren functioneerde. In plaats daarvan werd onafhankelijk publiek toezicht voorgesteld als een alternatieve manier om het toezicht op accountantscontroles te organiseren, met als doel het vertrouwen te herstellen in het accountantsberoep en de kwaliteit van haar werkzaamheden en de publieke functie ervan te waarborgen.

Tegelijkertijd hebben wet- en regelgevers over de hele wereld onafhankelijkheidseisen aangescherpt, of overwegen dat te gaan doen, in een poging de kwaliteit van de accountantscontrolete verbeteren en het publiekevertrouwen in de controleverklaringen van accountants te herwinnen. Veel landen hebben een verbod geïntroduceerd op het verlenen van (de meeste) andere diensten aan controlecliënten die worden beschouwd als organisaties van openbaar belang (OOB's; dat wil zeggen, beursgenoteerde ondernemingen, banken en verzekeraars). Verder is, in aanvulling op de reeds bestaande roulatieverplichting voor individuele partners, kantoorroulatie overwogen of zelfs al ingevoerd. Deze initiatieven zijn tekenend voor een breed gedeeld beeld dat de onafhankelijkheid van accountants en accountantsorganisaties verder moet worden versterkt, niet alleen in wezen, maar ook in schijn, om de kwaliteit van de accountantscontrole te waarborgen.

De governance van accountantsorganisaties (dat wil zeggen, organisatiestructuur, kwaliteitsbeheersingsbeleid, personeelsbeleid, onafhankelijkheid en ethiek) is een steeds belangrijker onderwerp geworden op de agenda van regelgevende instanties. De governance van een accountantsorganisatie heeft naar verwachting een significante invloed op de kwaliteit van de accountantscontrole die wordt uitgevoerd door (accountants van) die accountantsorganisatie. Het vergroten van de transparantie van de governance en het professionele handelen, in het bijzonder door het publiceren van kwaliteitsindicatoren, staat hoog op de agenda van regelgevende instanties. Van transparantie van accountantsorganisaties door middel van kwaliteitsindicatoren wordt aangenomen dat die het vermogen van marktdeelnemers vergroot de kwaliteit van de accountantscontrole waar te nemen, wat differentiatie en concurrentie tussen accountantsorganisaties op basis van publiek beschikbare gegevens mogelijk maakt, en accountantsorganisaties stimuleert de kwaliteit van de accountantscontrole te verhogen (o.a. Bedard et al 2010; PCAOB 2015). 


\section{Drie Empirische Studies}

Het doel van dit proefschrift is empirisch te onderzoeken hoe deze regelgevende onderwerpen (publiek toezicht, onafhankelijkheid en kwaliteitsindicatoren) verband houden met de kwaliteit van de accountantscontrole. Door gebruik te maken van de unieke toegang tot gegevens over accountantsorganisaties bij de Nederlandse toezichthoudende instantie, draagt dit proefschrift bij aan de bestaande literatuur over deze onderwerpen door voor verschillende aspecten van de kwaliteit van de accountantscontrole vanuit nieuwe perspectieven te bekijken.

In de eerste studie, gepresenteerd in hoofdstuk 2, wordt de effectiviteit van publiek toezicht onderzocht door te testen of (a) de publieke toezichthoudende instantie de kwaliteit van accountantscontroles kan onderscheiden in haar eerste inspectieronde en (b) de kwaliteit van de accountantscontrole verbetert na die eerste inspectieronde. In het bijzonder wordt getest of er een verband bestaat tussen de uitkomst van de eerste inspectieronde voor een accountantsorganisatie (dat wil zeggen, 'materiële bevindingen' of 'geen materiële bevindingen') en de kwaliteit van de winst, en met daarop volgende veranderingen in de kwaliteit van de winst, van ondernemingen die zijn gecontroleerd door die accountantsorganisatie.

Op basis van een steekproef van eerste inspectierapporten van 51 accountantsorganisaties, die meer dan 85 procent van de markt voor wettelijke controles in Nederland afdekt, en 6609 controlecliënt-jaar observaties omvat voor de jaren 2005-2008, blijkt dat ondernemingen die zijn gecontroleerd door accountantsorganisaties met materiële bevindingen in hun eerste inspectie door de publieke toezichthoudende instantie lagere winstkwaliteit hebben dan ondernemingen die zijn gecontroleerd door accountantsorganisaties zonder materiële bevindingen. Deze bevinding geldt voor accountantsorganisaties met en zonder OOB-cliënten, met uitzondering van de groep kleinste niet-OOB-accountantsorganisaties. Echter, de resultaten leveren geen bewijs voor een verbetering van de kwaliteit van de accountantscontrole na de eerste inspectieronde, wat misschien wel het belangrijkste aspect is van effectief publiek toezicht. Deze bevinding wijkt af van eerder Amerikaans bewijs dat duidt op een verbetering van controlekwaliteit na PCAOB-inspecties. Een mogelijke verklaring voor dit verschil in bevindingen is dat accountantsorganisatie-specifieke inspectierapporten in Nederland tot 2014 niet openbaar werden gemaakt.

Uit aanvullende analyses blijkt dat de aard van de tekortkomingen die de publieke toezichthoudende instantie heeft geïdentificeerd en die het best in staat zijn controlekwaliteit te onderscheiden, betrekking hebben op de uitvoering en de documentatie van controleopdrachten, onafhankelijkheid en kwaliteitsbeoordelingen. Verder wordt geen bewijs gevonden voor een verband tussen de uitkomsten van de voorafgaande collegiale toetsingen van accountantsorganisaties en de winstkwaliteit van controlecliënten. Dit suggereert dat het voorgaande Nederlandse systeem van collegiale toetsingen mogelijk 'amicaal' was. Dit is niet geheel onverwacht, aangezien accountantsorganisaties hun eigen collegiale toetser mochten selecteren. Bovendien is deze uitkomst in overeen- 
stemming met eerdere bevindingen. Er is ook geen bewijs dat controlekwaliteit is verbeterd na de collegiale toetsingen. Alles bij elkaar wordt geconcludeerd dat de publieke toezichthoudende instantie in staat is om controlekwaliteit te onderscheiden, in tegenstelling tot het voorafgaande systeem van collegiale toetsingen, maar dat beide systemen geen verbetering van de controlekwaliteit hebben gebracht.

In de tweede studie, gepresenteerd in hoofdstuk 3, wordt de effectiviteit van onafhankelijkheidsregelgeving onderzocht door na te gaan hoe accountantsorganisaties hun inspanningen en/of risicopremies aanpassen wanneer zij een zakelijke relatie onderhouden met een controlecliënt. In het bijzonder wordt het verband onderzocht tussen het bestaan van een dergelijke zakelijke relatie en de kwaliteit van de accountantscontrole, afgeleid uit zowel de prijs van de controle als de kwaliteit van de door de cliënt gerapporteerde winst.

Op basis van een steekproef van Nederlandse ondernemingen met een zakelijke relatie met hun accountantsorganisatie gekoppeld aan vergelijkbare Nederlandse ondernemingen zonder een dergelijke zakelijke relatie, blijken zakelijke relaties consequent geassocieerd met een hogere prijs van de controle en, met name in die situaties waarin de zakelijke relatie samenvalt met een hoge prijs van niet-controlediensten in vergelijking met de prijs van de controle, met hogere winstkwaliteit. Deze resultaten suggereren dat accountantsorganisaties de zakelijke relatie beschouwen als een bedreiging voor de onafhankelijkheid van de accountant en proberen deze bedreiging met waarborgen te mitigeren, zoals vereist door de onafhankelijkheidsregelgeving, bijvoorbeeld met aanvullende controle- of reviewwerkzaamheden of andere kwaliteitsbeheersingsmaatregelen. Echter, alternatieve verklaringen voor de hogere prijs van de controle, bijvoorbeeld dat de accountantsorganisatie een risicopremie in rekening brengt bij de controlecliënt, zijn niet volledig uitgesloten. Belangrijk is dat geen bewijs wordt gevonden voor verminderde onafhankelijkheid, wat naar verwachting zou hebben geleid tot een lagere prijs van de controle en een lagere kwaliteit van de gerapporteerde winst. Deze resultaten lijken robuust in meerdere gevoeligheidsanalyses op transversale deelverzamelingen (bijvoorbeeld op basis van de grootte van de accountantsorganisatie (Big 4 of niet-Big 4), type controlecliënt (OOB of niet-OOB), de vraag naar kwaliteit van de accountantscontrole en cliëntrisico), alsmede voor een alternatieve maatstaf voor zakelijke relaties (dat wil zeggen, de monetaire waarde van deze zakelijke relaties) en alternatieve koppelingsmethoden.

In het derde onderzoek, gepresenteerd in hoofdstuk 4, wordt onderzocht of governancekenmerken van accountantsorganisaties bruikbaar zijn als kwaliteitsindicatoren voor de accountantscontrole. Dit wordt gedaan door te testen of accountantsorganisaties met sterkere governancemechanismen minder kans hebben om te worden geconfronteerd met ontevredenheid van belanghebbenden, de aandacht te trekken van de toezichthouder, of de controlemarkt te verlaten. De governance van accountantsorganisaties is geoperationaliseerd door variabelen met betrekking tot de organisatiestructuur en het kwaliteitsbeheersingssysteem. 
Op basis van een steekproef van alle actieve accountantsorganisaties met een vergunning om wettelijke controles uit te voeren in Nederland, tonen univariate testresultaten aan dat veel governancekenmerken van accountantsorganisaties significant verschillend zijn voor Big 8 en niet-Big 8-accountantsorganisaties, in de eerdere versus latere jaren van publiek toezicht, en of accountantsorganisaties al dan niet geconfronteerd werden metontevredenheid van belanghebbenden, verhoogdeaandacht van de toezichthouder ondervonden of de controlemarkt verlieten. Multivariate analyses leveren bewijs dat verschillende governancekenmerken van accountantsorganisaties verband houden met specifieke maatstaven voor de kwaliteit van de accountantscontrole gemeten op organisatieniveau, zij het in verschillende mate. De resultaten laten in het bijzonder zien dat kleinere accountantsorganisaties, met verwachte organisatorische veranderingen of discontinuiteit, en met meer klanten waarvoor zij meer niet-controlediensten dan controlediensten verlenen, een hogere mate van ontevredenheid van belanghebbenden ervaren. De publieke toezichthoudende instantie lijkt haar aandacht te richten op de grotere accountantsorganisaties met meer op controle georiënteerde accountants en op accountantsorganisaties met een hoger 'risicoprofiel' (dat wil zeggen, accountantsorganisaties met een hoger aandeel nietaccountants in de raad van bestuur, niet onderworpen aan SRA-kwaliteitstoetsingen, met een verhoogde mate van ontevredenheid van belanghebbenden in het voorgaande jaar, met een hoger cumulatief aantal geregistreerde signalen, en niet-Big 8-accountantsorganisaties met een hoger aandeel controlecliënten waarvoor de prijs van de controle lager is dan de prijs voor andere verleende diensten en met hogere volatiliteit in hun cliëntenportefeuille). Accountantsorganisaties die de markt voor wettelijke controles verlaten lijken kleiner te zijn, vaker 'problemen' te ervaren (dat wil zeggen, een hogere kans op verwachte organisatorische veranderingen of discontinuiteit, meer ontevredenheid van belanghebbenden, verhoogde aandacht van de publieke toezichthoudende instantie in het voorgaande jaar, en meer signalen geregistreerd door de publieke toezichthoudende instantie), en minder kans om de kwaliteitsinvestering te hebben gedaan van de benoeming van een compliance officer. Interessant is dat aanvullende analyses aantonen dat de informatieve waarde van de governancekenmerken van accountantsorganisaties is toegenomen in de tijd. 


\section{Acknowledgements}

When you spend more than seven years working on your dissertation, with a full-time job 'on the side', you are bound to have many people involved in the process, one way or the other. I extend my deepest gratitude to all of them. A special few I would like to thank in particular.

Ann Vanstraelen and Jean Bedard, my supervisors, for guiding me through the challenging process of doing academic research and making it a truly pleasant and valuable learning experience.

Steven Maijoor, for hiring me at the AFM, inspiring me to do research, and being part of the evaluation committee.

Roger Meuwissen, Martin Carree, and Roger Simnett, the other members of the evaluation committee, for providing me with their insightful comments on my research.

Peter Eimers, for showing me how to successfully combine a career in both research and practice.

Katrien Van de Poel, for co-authoring my first research paper and introducing me in the wondrous world of STATA.

Caren Schelleman, for the coffee and being my go-to-colleague at the UM.

Janine van Diggelen, Gerben Everts, Ruud de Hollander, Franciska Pouw, Peter Veenis, and Marianne van der Zijde, my (former) bosses at the AFM, for allowing me to use valuable AFM resources, time and data, and encouraging me along the way.

Eva Bouwmans and Christine Scheper, my paranymphs, for their mental support, being fun and inspirational colleagues, and keeping me from running.

Melissa van den Broek, Barbara Majoor, and Maaike Stouten, for sharing with me their experiences with $\mathrm{PhD}$ research.

My other colleagues at the AFM, for being interested and supportive till the end.

My friends from 'Res Cogitans', 'LaDanse', and others, for your friendship, understanding, and welcome distractions.

My family, for their love and support.

Tim and Dorus, for being my home.

Martijn van Opijnen

Utrecht, March 2016 


\section{Curriculum Vitae}

Martijn van Opijnen was born in Elst (municipality of Rhenen), the Netherlands, on August $2^{\text {nd }} 1981$. He attended pre-university secondary education (Voorbereidend Wetenschappelijk Onderwijs) at Regionale Scholengemeenschap Het Rhedens in Rozendaal and graduated cum laude in 1999. From 1999 to 2004, he studied Economics at Maastricht University (Netherlands) specializing in International Auditing and Control. In the Fall semester of 2003, he attended Brandeis University's International Business School in Waltham, Massachusetts (United States of America) and completed courses in the MBA program. Back in Maastricht, he wrote his Master's thesis, entitled 'Auditor Switching and Discretionary Accruals. An Empirical Study for Dutch Public and Private Companies', under the supervision of Prof. Dr. Steven J. Maijoor and graduated in June 2004.

In September 2004, Van Opijnen started working as an Associate Supervision Officer for the Netherlands Authority for the Financial Markets (AFM), in the division responsible for public oversight of audit firms in the Netherlands. At the same time, he enrolled in the post-master education at Maastricht University Business School to become a chartered accountant (registeraccountant). He graduated in January 2009 and has been registered with The Netherlands Institute of Chartered Accountants (Koninklijke Nederlands Beroepsorganisatie van Accountants - NBA) since April $22^{\text {nd }} 2009$.

In November 2008, in his spare time and generously supported by the AFM, Van Opijnen started writing his PhD dissertation under the supervision of Prof. Dr. Ann Vanstraelen (Maastricht University, Netherlands) and Prof. Dr. Jean C. Bedard (Bentley University, United States of America). In 2009, as part of the AFM Top Talent Program supporting his $\mathrm{PhD}$ research, he attended an intensive individual language training course in English at the renowned language institute Regina Coeli in Vught (Netherlands) and participated in the Summer School Program at the London School of Economics and Political Sciences (United Kingdom) and followed the course 'Introduction to Econometrics'.

Van Opijnen presented his research at various international conferences, e.g., the European Audit Research Network (EARNet) Symposium (2009, Valencia, Spain; 2011, Bergen, Norway; and 2015, Lausanne, Switzerland), the American Accounting Association Auditing Midyear Meeting (2010, San Diego, United States of America), the European Accounting Association Annual Congress (2010, Istanbul, Turkey), and the International Symposium on Audit Research (ISAR) (2014, Maastricht, Netherlands). At the AFM, Van Opijnen lastly held the position of Senior Policy Advisor at the department of Audit \& Reporting Quality Oversight and acted as project lead responsible for monitoring the implementation of audit quality improvement measures by the PIE audit firms. 